\title{
Synthesis of Vanadium Oxo Alkylidene Complex and its Reactivity in Ring-Closing Olefin Metathesis Reactions
}

\author{
Dmitry S. Belov, ${ }^{1}$ Didac A. Fenoll, ${ }^{2}$ Indranil Chakraborty, ${ }^{1}$ Xavier Solans-Monfort,${ }^{2}$ and \\ Konstantin V. Bukhryakov, ${ }^{1 *}$
}

${ }^{1}$ Department of Chemistry and Biochemistry, Florida International University, Miami, FL 33199, USA

${ }^{2}$ Departament de Química, Universitat Autònoma de Barcelona, 08193 Bellaterra, Spain

\section{Supporting Information}

\section{Table of Contents}

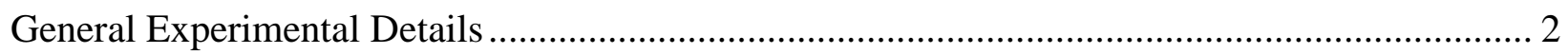

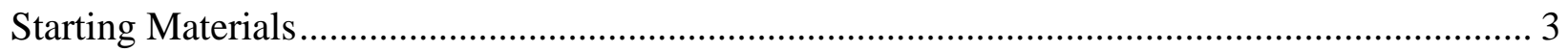

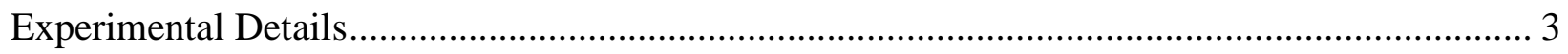

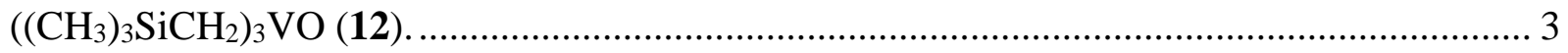

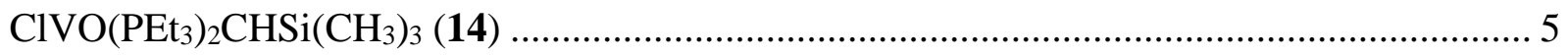

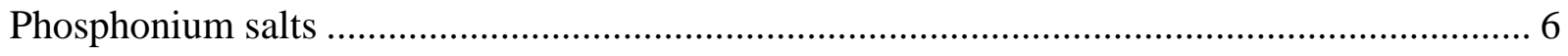

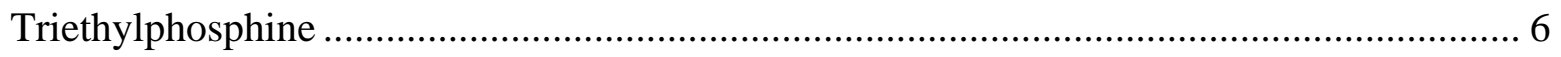

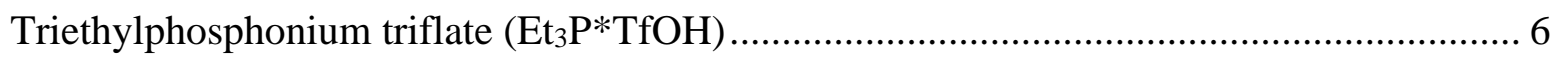

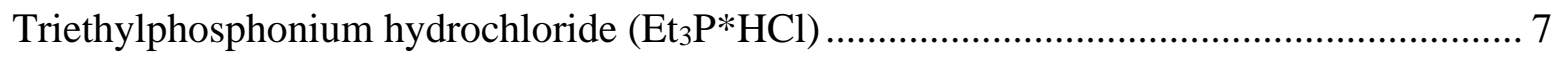

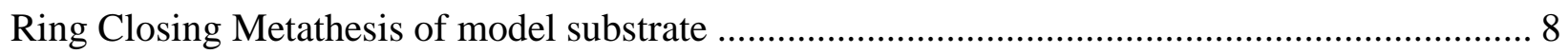

General procedure for solvent screen …………………................................................. 8

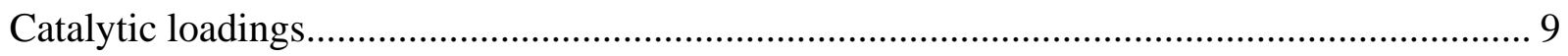

Open vial experiment:

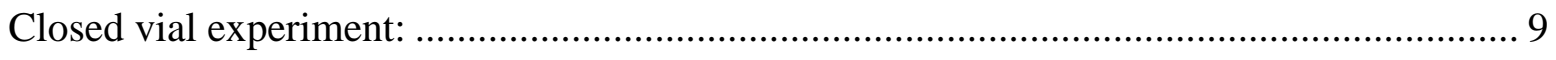

Scope

Synthesis of substrates for RCM reaction....................................................................... 10

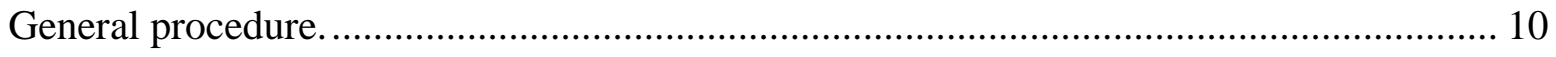




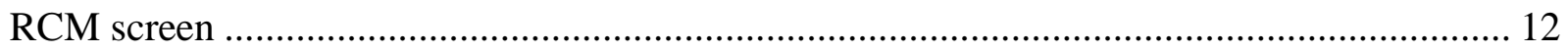

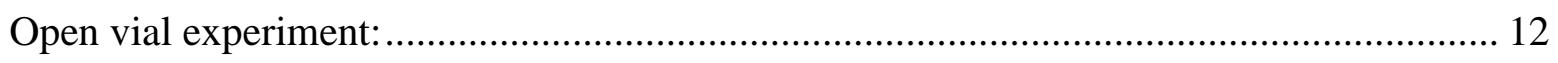

Closed vial experiment (volatile substrates): ..................................................................... 12

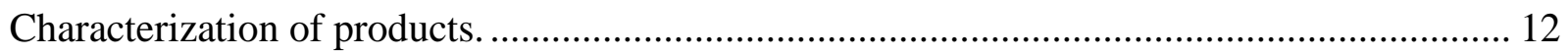

1-(thiophen-2-ylsulfonyl)-2,5-dihydro-1H-pyrrole (22) ............................................... 13

8-((2,5-dihydro-1H-pyrrol-1-yl)sulfonyl)quinoline (23) .................................................. 13

5-((2,5-dihydro-1H-pyrrol-1-yl)sulfonyl)-N,N-dimethylnaphthalen-1-amine (24).............. 14

4-((2,5-dihydro-1H-pyrrol-1-yl)sulfonyl)-3,5-dimethylisoxazole (27) ................................ 14

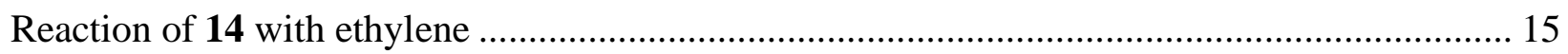

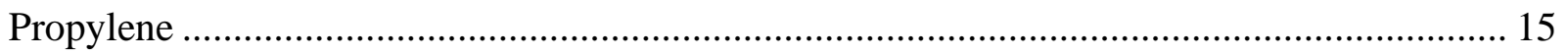

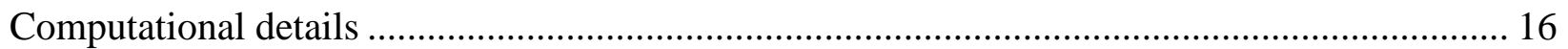

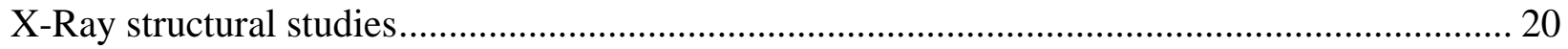

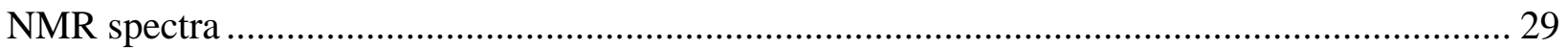

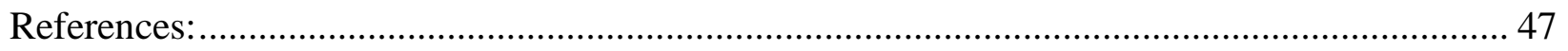

\section{General Experimental Details}

All air- and moisture-sensitive materials were manipulated in a nitrogen-filled MBraun glovebox or on a dual-manifold Schlenk line. All glassware was dried in an oven prior to use $\left(160{ }^{\circ} \mathrm{C}\right)$. Tetrahydrofuran (THF), diethyl ether, $i \operatorname{Pr}_{2} \mathrm{O}$, pentane, and toluene were distilled from $\mathrm{Na} /$ benzophenone under nitrogen and stored under $3 \AA$ molecular sieves in the glovebox. $\mathrm{CH}_{2} \mathrm{Cl}_{2}$ was distilled over $\mathrm{CaH}_{2}$ under nitrogen and stored under $3 \AA$ molecular sieves in the glovebox. $\mathrm{CDCl}_{3}, \mathrm{CD}_{2} \mathrm{Cl}_{2}, \mathrm{C}_{6} \mathrm{D}_{6}$ and tol- $d_{8}$ were dried over $3 \AA$ molecular sieves in the glovebox. ${ }^{1} \mathrm{H}$ NMR spectra were obtained on Bruker $400 \mathrm{MHz}$ spectrometers, and ${ }^{13} \mathrm{C}$ NMR spectra were obtained on $101 \mathrm{MHz}$ machines. Chemical shifts for ${ }^{1} \mathrm{H}$ and ${ }^{13} \mathrm{C}$ spectra are reported as parts per million and referenced to the residual ${ }^{1} \mathrm{H}$ or ${ }^{13} \mathrm{C}$ resonances of the deuterated solvent $\left({ }^{1} \mathrm{H} \delta: \mathrm{C}_{6} \mathrm{D}_{6} 7.16, \mathrm{CDCl}_{3}\right.$ 7.26; $\mathrm{CD}_{2} \mathrm{Cl}_{2} 5.32,{ }^{13} \mathrm{C} \delta: \mathrm{C}_{6} \mathrm{D}_{6} 128.06, \mathrm{CDCl}_{3} 77.16, \mathrm{CD}_{2} \mathrm{Cl}_{2}$ 54.00). All NMR data is reported as follows: chemical shift, multiplicity $(\mathrm{s}=$ singlet, $\mathrm{d}=$ doublet, $\mathrm{t}=$ triplet, $\mathrm{q}=$ quartet, $\mathrm{br}=$ broad, $\mathrm{m}$ 
$=$ multiplet), and coupling constants $(\mathrm{Hz})$, integration. Ultra-High Resolution MS analysis was conducted on a Bruker Solarix FT-ICR-MS instrument operated under positive $(+)$ ion mode equipped with an ESI source. Spectra were internally calibrated utilizing Agilent ESI-L with 3 calibration points, allowing a mass error of $<1 \mathrm{ppm}$ with standard deviation of $0.057 \mathrm{ppm}$.

\section{Starting Materials}

Reagents were purchased at the highest commercial quality and used without further purification unless otherwise stated. Vanadium (III) chloride (97\%), Styrene oxide (97+\%), Hydrogen chloride (1N solution in diethyl ether) was purchased from Acros Organics (trimethylsilyl)methymagnesium chloride (1M solution in diethyl ether), diallylamine (>98.0\%), 4-methoxynenzenesulfonyl chloride (>98\%), trifluoromethanesulfonic acid (>98\%) were purchased from TCI America. $p$-toluenesulfonyl chloride, dansyl chloride (96\%), sodium hydride were purchased from Alfa Aesar. 4-Dimethylaminopyridine was purchased from Oakwood chemicals. Triethylphosphine were purchased from Strem Chemical Inc. 3,5-dimethylisoxazole4-sulfonyl chloride (98\%), 8-quinolinsulfonyl chloride (98\%) were purchased Combi-Blocks. Triethylamine was purchased from Fisher chemical. Thiophene-2-sulfonyl chloride (96\%) was purchased from Matrix Scientific.

\section{Experimental Details}

$\left(\left(\mathrm{CH}_{3}\right)_{3} \mathrm{SiCH}_{2}\right)_{3} \mathrm{VO}(12)$.

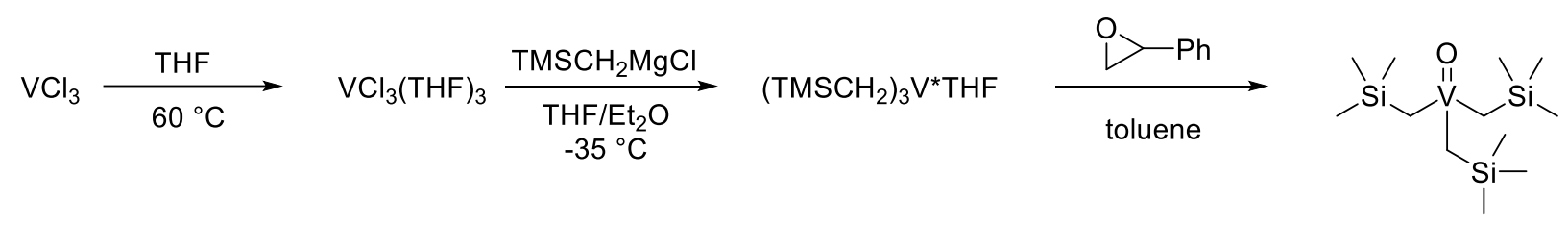

The procudere for the synthesis of $\left(\mathrm{TMSCH}_{2}\right)_{3} V^{*} \mathrm{THF}$ was adapted from reference 1 .

$\mathrm{VCl}_{3}(1.00 \mathrm{~g} 6.36 \mathrm{mmol})$ was suspended in THF $(64 \mathrm{~mL})$ and reaction mixture was stirred at 60 ${ }^{\circ} \mathrm{C}$ for $\sim 24 \mathrm{~h}$ to get a pink solution. The flask was transferred to a freezer $\left(-35^{\circ} \mathrm{C}\right)$ for several hours (during this time most of $\mathrm{VCl}_{3}(\mathrm{THF})_{3}$ precipitated from solution). ${ }^{2}$ The flask was transferred from a freezer and $\mathrm{TMSCH}_{2} \mathrm{MgCl}$ (1 M solution in ether, $19.7 \mathrm{~mL}, 19.7 \mathrm{mmol}, 3.1$ equiv) was added in the course of $\sim 1-2$ min to a vigorously stirred suspension (during the addition pink color changes to dark violet). The reaction mixture was stirred for 5 minutes at room temperature (to ensure 
dissolution of all material) and transferred to a freezer $\left(-35^{\circ} \mathrm{C}\right)$ for several hours (or overnight). The solvent was evaporated, and the residue was extracted with ether $(3 \times 50 \mathrm{~mL})$ and filtered from inorganic material. Ether was evaporated to give $\left(\mathrm{TMSCH}_{2}\right)_{3} \mathrm{~V} * \mathrm{THF}$ as a violet solid. $\left(\mathrm{TMSCH}_{2}\right)_{3} V^{*} \mathrm{THF}$ is unstable at room temperature but can be stored at $-35{ }^{\circ} \mathrm{C}$. Usually it was used immediately in the next step without purification.

$\left(\mathrm{TMSCH}_{2}\right)_{3} \mathrm{~V}^{*} \mathrm{THF}$ was dissolved in toluene $(200 \mathrm{~mL}$, high dilution is important, attempts to increase concentration results in decreased yield) and styrene oxide $(2.19 \mathrm{~mL}, 19.1 \mathrm{mmol}, 3.0$ equiv.) was added in a single portion (after addition quick change of color to green followed by slow change of color to yellow). The solution was heated to reflux for a short period of time $(\sim 1$ min) cooled to room temperature and left overnight. Toluene was evaporated (warming to 40-50 ${ }^{\circ} \mathrm{C}$ is acceptable to increase the rate of evaporation). Pentane $(100 \mathrm{~mL})$ was added to the residue and the mixture was thoroughly stirred with spatula. White precipitate (polymer from styrene oxide) was filtered and washed with additional amount of pentane $(2 \times 50 \mathrm{~mL})$. Pentane was evaporated and the residue was dissolved in a hot ether $(12-15 \mathrm{~mL})$, solution was filtered through syringe filter to a vial and transferred to a freezer $\left(-35^{\circ} \mathrm{C}\right)$. $\left(\mathrm{TMSCH}_{2}\right)_{3} \mathrm{VO}$ was precipitated as bright yellow needles. The precipitate was filtered off and washed with cold $\left(-35^{\circ} \mathrm{C}\right)$ ether $(2 \times 5 \mathrm{~mL})$ and dried in vacuum. Additional product can be recovered by concentration of filtrate to $1 / 3$ to $1 / 5$ of a volume. $\mathrm{M}=1.057 \mathrm{~g}(51 \%)$.

The product is very light sensitive (80\% decomposition was observed after 72 hours at RT in transparent vial). Compound was stored in a glovebox freezer $\left(-35^{\circ} \mathrm{C}\right)$ in a vial wrapped in aluminum foil. Surprisingly, the yield was not affected when the reaction mixture was protected from light.

$\mathrm{TMSCH}_{2} \mathrm{Li}$ can be used in the reaction instead of $\mathrm{TMSCH}_{2} \mathrm{MgCl}$, but the yield was reduced significantly $(\sim 15 \%)$. We think that LiCl cannot be completely separated from reaction mixture, and it interferes with the oxidation step.

${ }^{1}$ H NMR: (C6D6, 400 MHz) $\delta=0.16$ (s, 27H), 1.74-1.91 (br., 6H).

${ }^{13}$ C NMR: (C6D6, 100 MHz) $\delta=1.2,89.8-94.2$ (br.).

${ }^{1} \mathrm{H}$ NMR: $\left(\mathrm{CD}_{\mathbf{2}} \mathrm{Cl}_{2}, 400 \mathrm{MHz}\right) \boldsymbol{\delta}=0.08(\mathrm{~s}, 27 \mathrm{H}), 1.93-2.10(\mathrm{br} ., 6 \mathrm{H})$.

${ }^{13} \mathrm{C}$ NMR: $\left(\mathrm{CD}_{2} \mathrm{Cl}_{2}, 100 \mathrm{MHz}\right) \boldsymbol{\delta}=1.3,91.4$ - 96.4 (br.). 


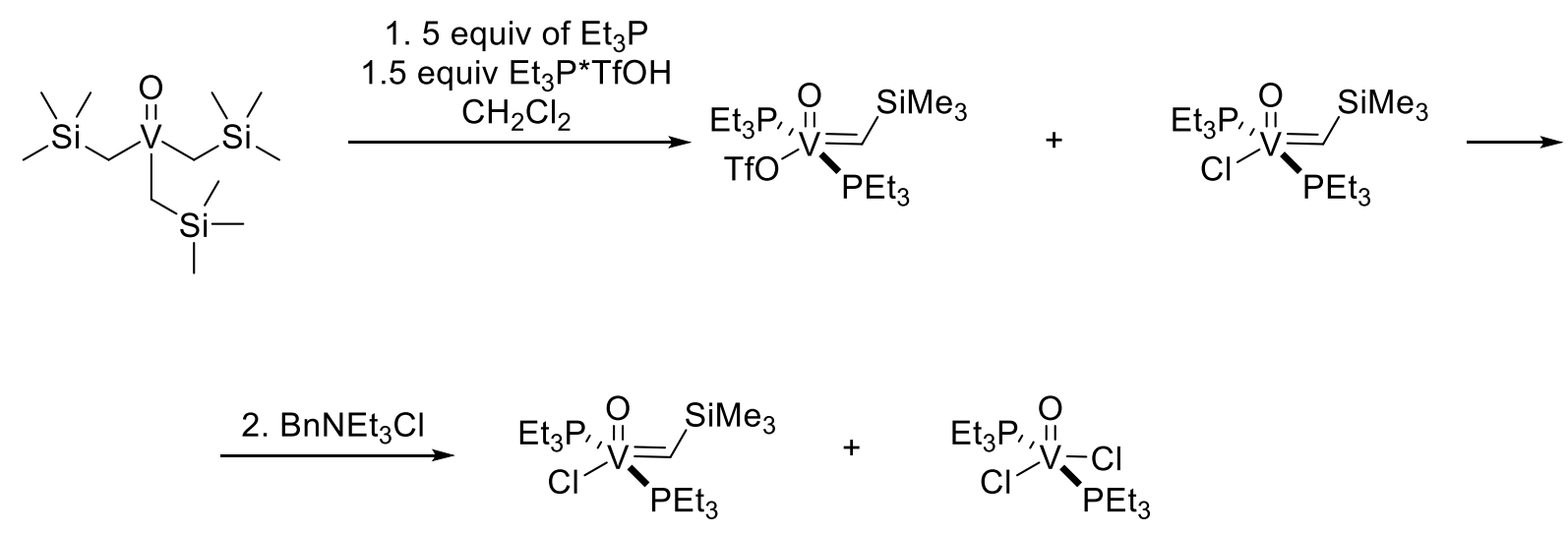

\section{$\operatorname{CIVO}\left(\mathrm{PEt}_{3}\right)_{2} \mathrm{CHSi}\left(\mathrm{CH}_{3}\right)_{3}(\mathbf{1 4})$}

$\left(\mathrm{TMSCH}_{2}\right)_{3} \mathrm{VO}(753 \mathrm{mg}, 2.29 \mathrm{mmol})$ was placed in a $20 \mathrm{~mL}$ vial with a stirring bar. Cold solid $\mathrm{Et}_{3} \mathrm{P}^{*} \mathrm{TfOH}$ (738 mg, $2.75 \mathrm{mmol}, 1.2$ equiv) was added followed by $\mathrm{Et}_{3} \mathrm{P}$ (1.69 mL, $11.46 \mathrm{mmol}$, 5 equiv) and $\mathrm{CH}_{2} \mathrm{Cl}_{2}(3.0 \mathrm{~mL})$. The vial was protected from light using aluminum foil and stirred for $\sim 6$ days at room temperature. The progress of the reaction was occasionally checked by ${ }^{1} \mathrm{H}$ NMR (sample $\sim 50 \mu \mathrm{L}$ of reaction mixture was dissolved in $1 \mathrm{~mL}$ of $\mathrm{C}_{6} \mathrm{D}_{6}$ ). Characteristic chemical shifts of TMS groups: starting material $0.15 \mathrm{ppm},\left(\mathrm{CH}_{3}\right)_{4} \mathrm{Si} 0.00 \mathrm{ppm}$, TfO-V=CHTMS $0.28 \mathrm{ppm}, \mathrm{Cl}-\mathrm{V}=\mathrm{CHTMS} 0.40 \mathrm{ppm}$ (Fig. S10). When the reaction is complete $\mathrm{BnNEt}_{3} \mathrm{Cl}(522 \mathrm{mg}$, $2.29 \mathrm{mmol}$ ) was added, and reaction mixture was stirred for $30 \mathrm{~min}$. Solvent was evaporated and residue was extracted with pentane $(3 \times 20 \mathrm{~mL})$ and filtered. Filtrate was evaporated and dissolved in $i \operatorname{Pr}_{2} \mathrm{O}(\sim 1 \mathrm{~mL})$, insoluble material was filtered through syringe filter. Filtrate was transferred to a freezer $\left(-35^{\circ} \mathrm{C}\right)$. After overnight the product crystallized as big yellow crystals. The solvent was removed using syringe and crystals were quickly washed with very small $(\sim 0.5 \mathrm{~mL})$ amount of cold $\left(-35^{\circ} \mathrm{C}\right) i \operatorname{Pr}_{2} \mathrm{O}$ and dried in vacuum. $\mathrm{M}=464 \mathrm{mg}(48 \%)$.

Occasionally a small amount of dark green crystal of impurity $\mathrm{Cl}_{2} \mathrm{VO}\left(\mathrm{PEt}_{3}\right)_{2}$ was observed (CCDC2093139). The crystals of impurity were separated manually.

${ }^{1}$ H-NMR: (400 MHz, C6D6) $\boldsymbol{\delta}=0.43$ (s, 9H), 0.94-1.10 (m, 18H), 1.48-1.70 (m, 12H), 16.07 (s, $\left.1 \mathrm{H}, \mathrm{V}=\mathrm{CH}_{\text {syn }}\right), 17.31\left(\mathrm{~s}, 0.03 \mathrm{H}, \mathrm{V}=\mathrm{CH}_{\text {anti }}\right)$.

${ }^{31}$ P NMR (162 MHz, C6 $\left.\mathbf{D}_{6}\right): \delta=17.3$ - 30.9 (br. m).

${ }^{13}$ C NMR: (100 MHz, C6 D6) $^{\delta}$ = 337.5-343.2 (br.), 16.6 (t, $\left.J=8.6 \mathrm{~Hz}\right), 8.1,1.6$.

Anal. Calcd for $\mathrm{C}_{16} \mathrm{H}_{40} \mathrm{ClOP}_{2} \mathrm{SiV}$ : C, 45.23\%; H, 9.49\%, Found: C, 45.36\%; H, 9.61\%. 


\section{Phosphonium salts}

\section{Triethylphosphine}

$\mathrm{Et}_{3} \mathrm{P}$ is commercially available. Spectra reported for convenience.

${ }^{1}$ H NMR: (CD2Cl2, $\left.400 \mathrm{MHz}\right) \boldsymbol{\delta}=1.36(\mathrm{q}, J=7.7 \mathrm{~Hz}, 1 \mathrm{H}), 1.03(\mathrm{dt}, J=14.0,7.7 \mathrm{~Hz}, 1 \mathrm{H})$.

31P NMR: $\left(\mathrm{CD}_{2} \mathrm{Cl}_{2}, 162 \mathrm{MHz}\right) \boldsymbol{\delta}=-19.0(\mathrm{dhept}, J=28.1,13.7 \mathrm{~Hz})$.

${ }^{31} \mathrm{P}\left[{ }^{1} \mathrm{H}\right]$ NMR: $\left(\mathrm{CD}_{2} \mathrm{Cl}_{2}, 162 \mathrm{MHz}\right) \delta=-19.0$.

${ }^{13}$ C NMR: $\left(\mathbf{C D}_{2} \mathrm{Cl}_{2}, 100 \mathrm{MHz}\right) \boldsymbol{\delta}=19.1(\mathrm{~d}, J=12.3 \mathrm{~Hz}), 10.0(\mathrm{~d}, J=12.9 \mathrm{~Hz})$.

${ }^{1}$ H NMR: (C6D6, 400 MHz) $\boldsymbol{\delta}=1.22(\mathrm{qd}, J=7.5,0.9 \mathrm{~Hz}, 1 \mathrm{H}), 0.98(\mathrm{dt}, J=13.7,7.5 \mathrm{~Hz}, 1 \mathrm{H})$.

${ }^{31}$ P NMR: (C6D6, $\left.162 \mathrm{MHz}\right) \boldsymbol{\delta}=-19.8(\mathrm{dh}, J=27.3,13.9 \mathrm{~Hz})$.

${ }^{31}$ P NMR: (C6D6, $\left.162 \mathrm{MHz}\right) \delta=-19.8$.

${ }^{13}$ C NMR: (C6D6, 100 MHz) $\delta=19.1(\mathrm{~d}, J=13.7 \mathrm{~Hz}), 9.9(\mathrm{~d}, J=13.4 \mathrm{~Hz})$.

${ }^{1}$ H NMR: $\left(\mathbf{C D C l}_{3}, 400 \mathrm{MHz}\right) \boldsymbol{\delta}=1.36(\mathrm{q}, J=7.6 \mathrm{~Hz}, 1 \mathrm{H}), 1.02(\mathrm{dt}, J=14.1,7.7 \mathrm{~Hz}, 2 \mathrm{H})$.

31P NMR: (CDCl3, $162 \mathrm{MHz}) \boldsymbol{\delta}=-18.7$ (dhept, $J=28.1,14.1 \mathrm{~Hz}$ ).

${ }^{31}$ P NMR: $\left(\mathrm{CDCl}_{3}, 162 \mathrm{MHz}\right) \delta=-18.7$.

${ }^{13}$ C NMR: $\left(\mathbf{C D C l}_{3}, \mathbf{1 0 0} \mathrm{MHz}\right) \boldsymbol{\delta}=18.4(\mathrm{~d}, J=11.3 \mathrm{~Hz}), 9.6(\mathrm{~d}, J=12.3 \mathrm{~Hz})$.

\section{Triethylphosphonium triflate $\left(\right.$ Et $\left._{3} \mathbf{P} * \mathbf{T f O H}\right)$}

Triethylphosphine $(1.00 \mathrm{~mL}, 6.79 \mathrm{mmol})$ was dissolved in ether $(10 \mathrm{~mL})$ and cooled to $-35{ }^{\circ} \mathrm{C}$. Trifluoromethanesulfonic acid $(0.600 \mathrm{~mL}, 6.79 \mathrm{mmol})$ was added dropwise to form a liquid salt as a separate phase. Reaction mixture was stirred for 5 minutes at room temperature and was transferred to a freezer at $-35^{\circ} \mathrm{C}$. After 2 hours ether was decanted from solid, and precipitate was dried in vacuum. The salt melts at room temperature and was stored at $-35^{\circ} \mathrm{C}$. $\mathrm{M}=1.69 \mathrm{~g}(93 \%)$. ${ }^{1} \mathbf{H}$ NMR: $\left(\mathbf{C D}_{2} \mathrm{Cl}_{2}, 400 \mathrm{MHz}\right) \boldsymbol{\delta}=6.09(\mathrm{ddq}, J=482.7,10.8,5.4 \mathrm{~Hz}, 1 \mathrm{H}), 2.31(\mathrm{dqd}, J=13.1$, 7.7, $5.4 \mathrm{~Hz}, 6 \mathrm{H}), 1.31(\mathrm{dt}, J=20.2,7.7 \mathrm{~Hz}, 9 \mathrm{H})$.

${ }^{19}$ F NMR: $\left(\mathrm{CD}_{2} \mathrm{Cl}_{2}, 376 \mathrm{MHz}\right) \delta=-79.0$.

${ }^{31}$ P NMR: $\left(\mathrm{CD}_{2} \mathrm{Cl}_{2}, 162 \mathrm{MHz}\right) \delta=22.5$.

${ }^{13}$ C NMR: $\left(\mathbf{C D}_{2} \mathrm{Cl}_{2}, 100 \mathrm{MHz}\right) \boldsymbol{\delta}=121.3(\mathrm{q}, J=320.5 \mathrm{~Hz}), 10.3(\mathrm{~d}, J=48.0 \mathrm{~Hz}), 7.0(\mathrm{~d}, J=5.3$ $\mathrm{Hz}$ ). 
${ }^{1}$ H NMR: $\left(\mathbf{C D C l}_{3}, 400 \mathrm{MHz}\right) \boldsymbol{\delta}=6.09(\mathrm{ddq}, J=483.4,10.9,5.4 \mathrm{~Hz}, 1 \mathrm{H}), 2.44-2.25(\mathrm{~m}, 6 \mathrm{H}), 1.31$ (dt, $J=20.2,7.7 \mathrm{~Hz}, 1 \mathrm{H})$.

${ }^{19}$ F NMR: $\left(\mathrm{CDCl}_{3}, 376 \mathrm{MHz}\right) \delta=-78.5$.

${ }^{31}$ P NMR: (CDCl3, $\left.162 \mathrm{MHz}\right) \delta=22.7$.

${ }^{13}$ C NMR: $\left(\mathbf{C D C l}_{3}, \mathbf{1 0 0} \mathrm{MHz}\right) \boldsymbol{\delta}=120.8(\mathrm{q}, J=320.1 \mathrm{~Hz}), 10.0(\mathrm{~d}, J=48.1 \mathrm{~Hz}), 6.8(\mathrm{~d}, J=5.5$ $\mathrm{Hz})$.

\section{Triethylphosphonium hydrochloride $\left(\mathrm{Et}_{3} \mathbf{P} * \mathbf{H C l}\right)$}

Triethylphosphine $(1.00 \mathrm{~mL}, 6.79 \mathrm{mmol})$ was dissolved in ether $(20 \mathrm{~mL})$ and $1 \mathrm{M} \mathrm{HCl}$ in ether ( $8.14 \mathrm{~mL}, 8.14 \mathrm{mmol}, 1.2$ equiv) was added dropwise to form a white solid. Reaction mixture was stirred for 5 minutes at room temperature and filtered. The precipitate was dried in vacuum. $\mathrm{M}=1.03 \mathrm{~g}(98 \%)$.

${ }^{1} \mathrm{H}$ NMR: $\left(\mathrm{CD}_{2} \mathrm{Cl}_{2}, 400 \mathrm{MHz}\right) \boldsymbol{\delta}=7.32(\mathrm{~d}, J=497.3 \mathrm{~Hz}, 01 \mathrm{H}), 2.46(\mathrm{dq}, J=15.1,7.7,7.0 \mathrm{~Hz}$, $6 \mathrm{H}), 1.30(\mathrm{dt}, J=19.7,7.7 \mathrm{~Hz}, 9 \mathrm{H})$.

${ }^{31}$ P NMR: $\left(\mathrm{CD}_{2} \mathrm{Cl}_{2}, 162 \mathrm{MHz}\right) \delta=19.7$.

${ }^{13} \mathrm{C}$ NMR: $\left(\mathrm{CD}_{2} \mathrm{Cl}_{2}, 100 \mathrm{MHz}\right) \boldsymbol{\delta}=11.1(\mathrm{~d}, J=48.0 \mathrm{~Hz}), 7.37(\mathrm{~d}, J=5.6 \mathrm{~Hz})$.

${ }^{1} \mathrm{H}$ NMR: $\left(\mathbf{C D C l}_{3}, 400 \mathrm{MHz}\right) \boldsymbol{\delta}=\delta 7.14(\mathrm{~d}, J=495.5 \mathrm{~Hz}, 1 \mathrm{H}), 2.43(\mathrm{dt}, J=15.5,7.7 \mathrm{~Hz}, 6 \mathrm{H})$, $1.26(\mathrm{dt}, J=19.8,7.7 \mathrm{~Hz}, 9 \mathrm{H})$.

${ }^{31}$ P NMR: $\left(\mathrm{CDCl}_{3}, 162 \mathrm{MHz}\right) \delta=20.2$.

${ }^{13}$ C NMR: $\left(\mathbf{C D C l}_{3}, \mathbf{1 0 0} \mathrm{MHz}\right) \boldsymbol{\delta}=10.6(\mathrm{~d}, J=47.9 \mathrm{~Hz}), 7.1(\mathrm{~d}, J=5.5 \mathrm{~Hz})$. 


\section{Ring Closing Metathesis of model substrate}

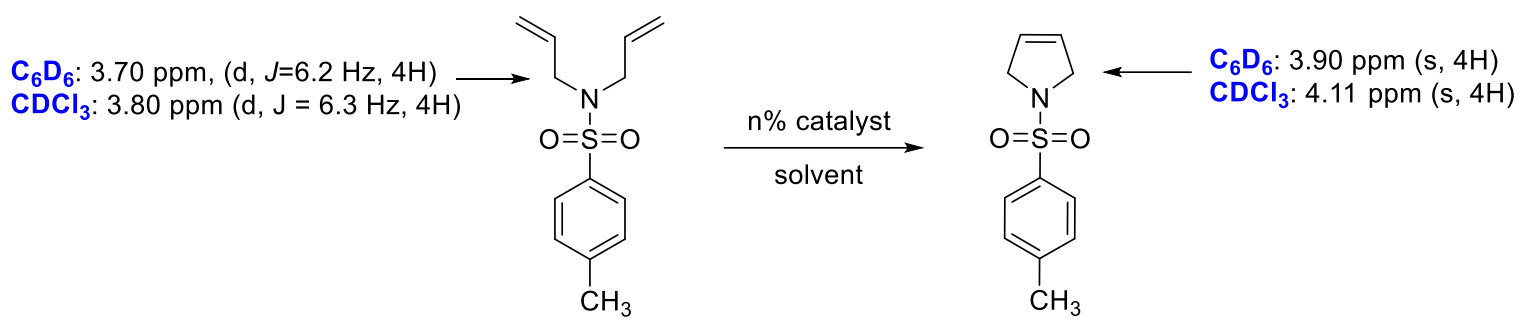

All experiments were performed in a nitrogen filled glovebox.

Catalyst stock solution was prepared immediately before the reaction in each experiment.

Conversion was estimated by integration methylene proton resonance of $\mathrm{N}, \mathrm{N}$-diallyl-4methylbenzenesulfonamide and 1-tosyl-2,5-dihydro-1H-pyrrole (Fig. S21).

\section{General procedure for solvent screen}

Complex 14 (4.3 mg, 5 mol. \%) was weighed into a HPLC vial, $1 \mathrm{~mL}$ of a solvent was added followed by $49 \mu \mathrm{L}$ of $N, N$-diallyl-4-methylbenzenesulfonamide $17(\sim 51 \mathrm{mg})$. The vials were tightly closed and were left stirred overnight at room temperature. Reaction mixtures in deuterated solvents were transferred to NMR tubes. Other reaction mixtures were transferred outside of glovebox evaporated and the residue was dissolved in $\mathrm{CDCl}_{3}$. Conversions were determined by ${ }^{1} \mathrm{H}$ NMR analysis (Table S1).

Table S1. Solvent screening, conversion of 17 to 18 in closed vials.

\begin{tabular}{|c|c|}
\hline Solvent & Conversion, \% \\
\hline $\mathrm{CDCl}_{3}$ & 75 \\
\hline $\mathrm{CD}_{2} \mathrm{Cl}_{2}$ & 72 \\
\hline $\mathrm{C}_{6} \mathrm{D}_{6}$ & 67 \\
\hline Toluene-d $^{8}$ & 67 \\
\hline $\mathrm{C}_{6} \mathrm{H}_{5} \mathrm{~F}$ & 72 \\
\hline THF & 58 \\
\hline Ether & 60 \\
\hline DME & 65 \\
\hline Pentane & 65 \\
\hline
\end{tabular}




\section{Catalytic loadings.}

\section{Open vial experiment:}

$21.3 \mathrm{mg}$ of complex $\mathbf{1 4}$ was dissolved in $1 \mathrm{~mL}$ of $\mathrm{CDCl}_{3}$. N,N-diallyl-4methylbenzenesulfonamide $17(50.3 \mathrm{mg})$ was added to six separate $8 \mathrm{~mL}$ vials equipped with stirring bars. $\mathrm{V}_{1} \mathrm{~mL}$ of $\mathrm{CDCl}_{3}$ was added to each vial followed by $\mathrm{V}_{2} \mathrm{~mL}$ of catalyst stock solution (Table S2). Each reaction was stirred in an open vial for $24 \mathrm{~h}$. By the end of experiment no solvent left in vials and a fresh $\mathrm{CDCl}_{3}(1 \mathrm{~mL})$ was added to each vial. The solutions were transferred to NMR tubes and conversions were measured by ${ }^{1} \mathrm{H}$ NMR (Table S3).

\section{Closed vial experiment:}

$21.3 \mathrm{mg}$ of complex 1 was dissolved in $1 \mathrm{~mL}$ of $\mathrm{CDCl}_{3}$. N,N-diallyl-4-methylbenzenesulfonamide $17(50.3 \mathrm{mg})$ was added to six separate HPLC vials equipped with stirring bars. $\mathrm{V}_{1} \mathrm{~mL}$ of $\mathrm{CDCl}_{3}$ was added to each vial followed by $\mathrm{V}_{2} \mathrm{~mL}$ of catalyst stock solution (Table S2). The vials were closed tightly and stirred for $24 \mathrm{~h}$. The solutions were transferred to NMR tubes and conversions were measured by ${ }^{1} \mathrm{H}$ NMR (Table 2).

Table S2.

\begin{tabular}{|c|c|c|c|c|c|c|}
\hline Cat, $\%$ & 1 & 2 & 3 & 4 & 5 & 6 \\
\hline $\mathrm{V}_{1}, \mu \mathrm{L}$ & 960 & 920 & 880 & 840 & 800 & 760 \\
\hline $\mathrm{V}_{2}, \mu \mathrm{L}$ & 40 & 80 & 120 & 160 & 200 & 240 \\
\hline
\end{tabular}

Table S3. Catalysts loading screening, conversion of $\mathbf{1 7}$ to $\mathbf{1 8 .}$

\begin{tabular}{|c|c|c|c|c|c|}
\hline \multicolumn{3}{|c|}{ Open vial } & \multicolumn{3}{|c|}{ Closed vial } \\
\hline $\begin{array}{l}\%, \\
\text { cat }\end{array}$ & Conversion, $\%$ & TON & $\%$, cat & Conversion, $\%$ & TON \\
\hline 1 & 59 & 59 & 1 & 56 & 56 \\
\hline 2 & 83 & 42 & 2 & 66 & 33 \\
\hline 3 & 91 & 30 & 3 & 69 & 23 \\
\hline 4 & 94 & 24 & 4 & 73 & 18 \\
\hline 5 & 96 & 19 & 5 & 76 & 15 \\
\hline 6 & 97 & 16 & 6 & 76 & 12 \\
\hline
\end{tabular}




\section{Scope}

1,7-Octadiene S1 (>97\%) and allyl sulfide S2 (>98\%) were purchased from TCI and used as received. 17, S24, S5 were prepared by reaction between diallylamine and appropriate sulfonyl chloride as described in reference ${ }^{3} .{ }^{1} \mathrm{H}$ and ${ }^{13} \mathrm{C}$ NMR data for $\mathbf{S 3}$ can be found in reference ${ }^{4}$. S6 was prepared by alkylation of aniline and purified by distillation under reduced pressure. ${ }^{5} \mathbf{S} 7$ was prepared by benzoylation of diallylamine. ${ }^{6} \mathbf{S 8}$ was prepared by alkylation of diethyl malonate. ${ }^{7}$

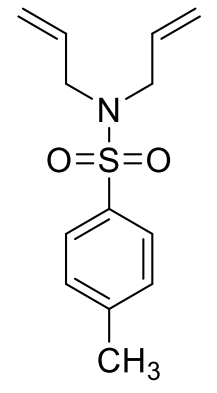

S3 (17)<smiles>C=CCN(CC=C)S(=O)(=O)c1ccc(OC)cc1</smiles>

S4

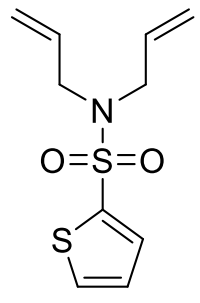

S5

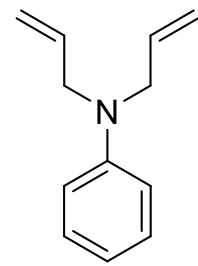

S6<smiles>C=CCN(CC=C)C(=O)c1ccccc1</smiles>

S7<smiles>C=CCC(CC=C)(C(=O)OCC)C(=O)OCC</smiles>

S8

Figure S1. Reported substrates for RCM.

\section{Synthesis of substrates for RCM reaction.}

\section{General procedure.}

To the solution of $\mathrm{ArSO}_{2} \mathrm{Cl}(5.4 \mathrm{mmol})$ in $\mathrm{CHCl}_{3}(15 \mathrm{~mL})$ was added DMAP (50-100 mg) followed by diallylamine $\left(1 \mathrm{~mL}, 8.1 \mathrm{mmol}, 1.5\right.$ equiv) and $\mathrm{Et}_{3} \mathrm{~N}(1.13 \mathrm{~mL}, 8.1 \mathrm{mmol}, 1.5 \mathrm{equiv})$. The reaction is slightly exothermic. The reaction mixture was stirred overnight and diluted with DCM $(20 \mathrm{~mL})$. The solution was washed with water $(20 \mathrm{~mL})$ and organic phase was separated and dry loaded on silica. Column chromatography afforded desired compounds.<smiles>O=S(=O)(Cl)c1cccc2cccnc12</smiles><smiles>C=CCNCC=C</smiles><smiles>C=CCN(CC=C)S(=O)(=O)c1cccc2cccnc12</smiles>

S9

\section{N,N-diallylquinoline-8-sulfonamide (S9)}

Eluent: hexanes/ethyl acetate $2: 1 . \mathrm{Rf}=0.3(3: 1$, hexanes/EA).

White solid. $\mathrm{M}=1.36 \mathrm{~g}(87 \%)$.

${ }^{1}$ H NMR: (CDCl3, $\left.400 \mathrm{MHz}\right) \boldsymbol{\delta}=9.05(\mathrm{dd}, J=4.2,1.8 \mathrm{~Hz}, 1 \mathrm{H}), 8.49(\mathrm{dd}, J=7.4,1.4 \mathrm{~Hz}, 1 \mathrm{H})$, $8.23(\mathrm{dd}, J=8.3,1.8 \mathrm{~Hz}, 1 \mathrm{H}), 8.01(\mathrm{dd}, J=8.2,1.3 \mathrm{~Hz}, 1 \mathrm{H}), 7.59(\mathrm{dd}, J=8.2,7.4 \mathrm{~Hz}, 1 \mathrm{H}), 7.51$ 
(dd, $J=8.4,4.2 \mathrm{~Hz}, 1 \mathrm{H}), 5.55(\mathrm{ddt}, J=16.6,10.1,6.3 \mathrm{~Hz}, 2 \mathrm{H}), 5.07$ (dq, $J=17.2,1.5 \mathrm{~Hz}, 2 \mathrm{H})$, $5.01(\mathrm{dt}, J=10.1,1.4 \mathrm{~Hz}, 2 \mathrm{H}), 4.10(\mathrm{~d}, J=6.2 \mathrm{~Hz}, 4 \mathrm{H})$.

${ }^{13}$ C NMR: $\left(\mathbf{C D C l}_{3}, \mathbf{1 0 0} \mathrm{MHz}\right) \boldsymbol{\delta}=151.1,144.1,138.7,136.5,133.8,133.3,132.7,129.0,125.5$, 122.1, 118.2, 50.1.

HRMS (m/z) calcd for $\mathbf{C}_{15} \mathbf{H}_{17} \mathbf{N}_{2} \mathbf{O}_{2} \mathbf{S}[\mathbf{M}+\mathbf{H}]^{+}$: 289.1005, found: 289.1003.<smiles>CN(C)c1cccc2c(S(=O)(=O)Cl)cccc12</smiles><smiles>C=CCNCC=C</smiles>

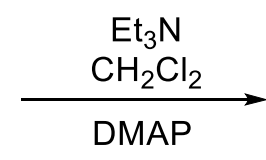<smiles>C=CCN(CC=C)S(=O)(=O)c1cccc2c(N(C)C)cccc12</smiles>

S10

N,N-diallyl-5-(dimethylamino)naphthalene-1-sulfonamide (S10)

Eluent: hexanes/ethyl acetate 5:1, 3:1. $\mathrm{Rf}=0.4$ (3:1, hexanes/EA).

Yellow oil. $\mathrm{M}=496 \mathrm{mg}(75 \%)$.

${ }^{1} \mathrm{H}$ NMR: $\left(\mathbf{C D C l}_{3}, 400 \mathrm{MHz}\right) \boldsymbol{\delta}=8.54(\mathrm{dt}, J=8.5,1.1 \mathrm{~Hz}, 1 \mathrm{H}), 8.38-8.15(\mathrm{~m}, 2 \mathrm{H}), 7.53$ (ddd, $J=15.2,8.6,7.5 \mathrm{~Hz}, 2 \mathrm{H}), 7.18(\mathrm{dd}, J=7.5,0.9 \mathrm{~Hz}, 1 \mathrm{H}), 5.59(\mathrm{ddt}, J=17.4,9.8,6.4 \mathrm{~Hz}, 2 \mathrm{H}), 5.12$ $(\mathrm{dtd}, J=14.7,2.9,1.4 \mathrm{~Hz}, 4 \mathrm{H}), 3.89$ (d, $J=6.3 \mathrm{~Hz}, 4 \mathrm{H}), 2.88$ (s, 6H).

${ }^{13}$ C NMR: $\left(\mathbf{C D C l}_{3}, \mathbf{1 0 0} \mathrm{MHz}\right) \boldsymbol{\delta}=151.9,135.2,132.9,130.6,130.3,130.2,130.1,128.1,123.3$, 119.6, 119.3, 115.3, 48.6, 45.6.

HRMS (m/z) calcd for $\mathbf{C}_{18} \mathbf{H}_{23} \mathbf{N}_{2} \mathbf{O}_{2} \mathbf{S}[\mathbf{M}+\mathbf{H}]^{+}$: 331.1475 , found: 331.1475 .<smiles>Cc1noc(C)c1S(=O)(=O)Cl</smiles><smiles>C=CCNCC=C</smiles>
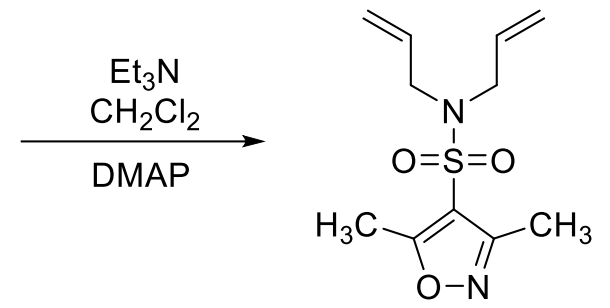

S11

\section{N,N-diallyl-3,5-dimethylisoxazole-4-sulfonamide (S11)}

Eluent: hexanes/ethyl acetate 5:1, 3:1. Rf=0.5 (3:1, hexanes/EA).

Clear oil. $\mathrm{M}=1.11 \mathrm{~g}(80 \%)$.

${ }^{1}$ H NMR: $\left(\mathbf{C D C l}_{3}, 400 \mathrm{MHz}\right) \boldsymbol{\delta}=5.65(\mathrm{ddt}, J=16.6,10.2,6.3 \mathrm{~Hz}, 2 \mathrm{H}), 5.35-5.06(\mathrm{~m}, 4 \mathrm{H}), 3.84$ (d, $J=6.2 \mathrm{~Hz}, 4 \mathrm{H}), 2.63$ (s, 3H), 2.38 (s, 3H). 
${ }^{13}$ C NMR: $\left(\mathbf{C D C l}_{3}, \mathbf{1 0 0} \mathbf{M H z}\right) \boldsymbol{\delta}=173.1,157.6,132.2,119.7,117.1,48.9,13.0,11.2$.

HRMS (m/z) calcd for $\mathbf{C}_{11} \mathbf{H}_{17} \mathbf{N}_{2} \mathbf{O}_{3} \mathbf{S}[\mathbf{M}+\mathbf{H}]^{+}:$257.0954, found: 257.0953 .

\section{RCM screen}

\section{Open vial experiment:}

Inside a nitrogen filled glovebox complex $14(38.2 \mathrm{mg}, 90 \mu \mathrm{mol}, 5 \mathrm{~mol}$. \%) was dissolved in 9.0 $\mathrm{mL}$ of $\mathrm{CDCl}_{3}$. To a nine separate $8 \mathrm{~mL}$ vials were added substrates S3-S11 (0.200 mmol) and a stirring bar. $1.0 \mathrm{~mL}$ of stock solution was added to each vial. Open vials were stirred for $24 \mathrm{~h}$. By the end of experiment no solvent left in a vials and a fresh $\mathrm{CDCl}_{3}(1.0 \mathrm{~mL})$ was added to each vial. The solutions were transferred to NMR tubes and conversions were measured by ${ }^{1} \mathrm{H}$ NMR (Fig. S21-S31).

\section{Closed vial experiment (volatile substrates):}

Inside a nitrogen filled glovebox complex $14(8.5 \mathrm{mg}, 20 \mu \mathrm{mol}, 5 \mathrm{~mol}$. \%) was dissolved in 2.0 $\mathrm{mL}$ of $\mathrm{CDCl}_{3}$. To two separate HPLC vials were added substrates S1-S2 (0.200 mmol) and a stirring bar. $1.0 \mathrm{~mL}$ of stock solution was added to each vial. The vials were closed tightly and stirred for $24 \mathrm{~h}$. The solutions were transferred to NMR tubes and conversions were measured by ${ }^{1} \mathrm{H}$ NMR (Fig. S21-S31).

For known RCM products the conversions were calculated based on the literature ${ }^{1} \mathrm{H}$ NMR data. (Fig. S21-S31). The relevant chemical shifts are listed on the figures S21-S31. ${ }^{1} \mathrm{H}$ NMR data for $\mathbf{1 8},{ }^{3} \mathbf{1 9},{ }^{8} \mathbf{2 0},{ }^{9} \mathbf{2 5},{ }^{6} \mathbf{2 6},{ }^{3} \mathbf{2 8}{ }^{10}$ can be found in the literature.

The unknown RCM products 22, 23, 24, 27 were isolated by column chromatography and characterized:

\section{Characterization of products.}

The solution in $\mathrm{CDCl}_{3}$ from $\mathbf{R C M}$ screen experiment was dry loaded on a small amount of silica gel. The product was isolated by column chromatography. 


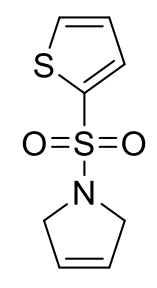

\section{1-(thiophen-2-ylsulfonyl)-2,5-dihydro-1H-pyrrole (22)}

The compound is known, but no NMR data has been reported. ${ }^{4}$

Eluent: hexanes/ethyl acetate $3: 1 . \mathrm{Rf}=0.2(3: 1$, hexanes/EA).

White solid. Isolated yield: $\mathrm{M}=35 \mathrm{mg}(81 \%)$.

${ }^{1}$ H NMR: $\left(\mathbf{C D C l}_{3}, 400 \mathrm{MHz}\right) \boldsymbol{\delta}=7.61-7.57(\mathrm{~m}, 2 \mathrm{H}), 7.13(\mathrm{dd}, J=4.7,4.0 \mathrm{~Hz}, 1 \mathrm{H}), 5.66(\mathrm{~s}$, $2 \mathrm{H}), 4.14(\mathrm{~s}, 4 \mathrm{H})$.

${ }^{13}$ C NMR: (CDCl3, 100 MHz) $\delta=137.0,132.1,132.0,127.6,125.5,55.2$.

HRMS (m/z) calcd for $\mathbf{C}_{8} \mathrm{H}_{10} \mathrm{NO}_{2} \mathbf{S}_{2}[\mathbf{M}+\mathbf{H}]^{+}$: 216.0147 , found: 216.0147 .

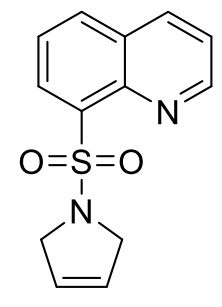

\section{8-((2,5-dihydro-1H-pyrrol-1-yl)sulfonyl)quinoline (23)}

Eluent: hexanes/ethyl acetate $1: 1 . \mathrm{Rf}=0.3(1: 1$, hexanes/EA).

Yellow solid. Isolated yield: $\mathrm{M}=38 \mathrm{mg}$ (73\%).

${ }^{1} \mathrm{H}$ NMR: (CDCl3, $\left.400 \mathrm{MHz}\right) \boldsymbol{\delta}=9.03(\mathrm{dd}, J=4.2,1.8 \mathrm{~Hz}, 1 \mathrm{H}), 8.47(\mathrm{dd}, J=7.4,1.5 \mathrm{~Hz}, 1 \mathrm{H})$, $8.22(\mathrm{dd}, J=8.3,1.8 \mathrm{~Hz}, 1 \mathrm{H}), 8.01(\mathrm{dd}, J=8.2,1.5 \mathrm{~Hz}, 1 \mathrm{H}), 7.60(\mathrm{dd}, J=8.2,7.3 \mathrm{~Hz}, 1 \mathrm{H}), 7.49$ (dd, $J=8.3,4.2 \mathrm{~Hz}, 1 \mathrm{H}), 5.65(\mathrm{~s}, 2 \mathrm{H}), 4.48(\mathrm{~s}, 4 \mathrm{H})$.

${ }^{13}$ C NMR: (CDCl3, 100 MHz) $\delta=151.2,144.3,137.1,136.6,133.5,133.4,129.2,125.5,125.5$, 122.1, 55.3.

HRMS (m/z) calcd for $\mathbf{C}_{13} \mathbf{H}_{13} \mathbf{N}_{2} \mathbf{O}_{2} \mathbf{S}[\mathbf{M}+\mathbf{H}]^{+}:$261.0692, found: 261.0692 . 


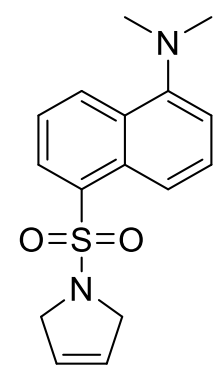

5-((2,5-dihydro-1H-pyrrol-1-yl)sulfonyl)-N,N-dimethylnaphthalen-1-amine (24)

Eluent: hexanes/ethyl acetate $3: 1 . \mathrm{Rf}=0.3(3: 1$, hexanes/EA).

Beige solid. Isolated yield: $\mathrm{M}=51 \mathrm{mg}(84 \%)$.

${ }^{1}$ H NMR: (CDCl3, $\left.400 \mathrm{MHz}\right) \boldsymbol{\delta}=8.53(\mathrm{dt}, J=8.5,1.1 \mathrm{~Hz}, 1 \mathrm{H}), 8.48(\mathrm{dt}, J=8.7,1.0 \mathrm{~Hz}, 1 \mathrm{H})$, $8.11(\mathrm{dd}, J=7.3,1.3 \mathrm{~Hz}, 1 \mathrm{H}), 7.53(\mathrm{ddd}, J=17.8,8.6,7.4 \mathrm{~Hz}, 2 \mathrm{H}), 7.18(\mathrm{dd}, J=7.6,1.0 \mathrm{~Hz}, 1 \mathrm{H})$, $5.71(\mathrm{~s}, 2 \mathrm{H}), 4.24(\mathrm{~s}, 4 \mathrm{H}), 2.87(\mathrm{~s}, 6 \mathrm{H})$.

${ }^{13}$ C NMR: $\left(\mathbf{C D C l}_{3}, \mathbf{1 0 0} \mathrm{MHz}\right) \boldsymbol{\delta}=151.8,134.4,130.5,130.4,130.3,128.67,128.1,125.5,123.3$, $119.8,115.3,54.7,45.5$.

HRMS (m/z) calcd for $\mathbf{C}_{16} \mathrm{H}_{19} \mathrm{~N}_{2} \mathrm{O}_{2} \mathrm{~S}[\mathbf{M}+\mathbf{H}]^{+}$: 303.1162 , found: 303.1160 .<smiles>Cc1noc(C)c1S(=O)(=O)N1CC=CC1</smiles>

4-((2,5-dihydro-1H-pyrrol-1-yl)sulfonyl)-3,5-dimethylisoxazole (27)

Eluent: hexanes/ethyl acetate $3: 1,1: 1 . \mathrm{Rf}=0.3$ (3:1, hexanes/EA).

White solid. Isolated yield: $\mathrm{M}=40 \mathrm{mg}(88 \%)$.

${ }^{1}$ H NMR: (CDCl3, 400 MHz) $\boldsymbol{\delta}=5.74$ (s, 2H), 4.13 (s, 4H), 2.64 (s, 3H), 2.40 (s, 3H).

${ }^{13}$ C NMR: $\left(\mathbf{C D C l}_{3}, \mathbf{1 0 0} \mathrm{MHz}\right) \boldsymbol{\delta}=173.5,157.9,125.5,115.4,54.4,13.1,11.4$.

HRMS (m/z) calcd for $\mathbf{C}_{9} \mathrm{H}_{13} \mathbf{N}_{2} \mathbf{O}_{3} \mathbf{S}[\mathbf{M}+\mathbf{H}]^{+}$: 229.0641, found: 229.0640 . 


\section{Reaction of 14 with ethylene}

Ethylene was bubbled through $\mathrm{C}_{6} \mathrm{D}_{6}(\sim 3 \mathrm{~mL})$ for 30 minutes. The resulted solution was dried over $3 \AA ̊$ molecular sieves $(0.5 \mathrm{~g})$ overnight. The ethylene solution was filtered into J. Young tube ( $90 \%$ of tube volume was filled with solution). Complex 14 (35 mg) was added, the J. Young tube was closed and the mixture was shaken for 1 minute to ensure dissolution of $\mathbf{1 4}$. The color slowly changed from yellow to brown along with formation of jellylike precipitate. Fragment of ${ }^{1} \mathrm{H}$ NMR is shown on Fig S11.

\section{Propylene}

${ }^{1}$ H NMR: (C6D6, 400 MHz) $\boldsymbol{\delta}=5.79-5.63(\mathrm{~m}, 1 \mathrm{H}), 5.00(\mathrm{dp}, J=17.0,1.8 \mathrm{~Hz}, 1 \mathrm{H}), 4.94$ (ddt, $J$ $=10.0,2.3,1.3 \mathrm{~Hz}, 1 \mathrm{H}), 1.55(\mathrm{dt}, J=6.5,1.6 \mathrm{~Hz}, 3 \mathrm{H})$. 


\section{Computational details}

All calculations are carried out with the B3LYP density functional ${ }^{11,12}$ as implemented in Gaussian16 package. ${ }^{13}$ Grimme's D3 empirical correction is added to account for dispersion forces. ${ }^{14}$ The catalyst deactivation pathways of both $\mathbf{5 b}$ and $\mathbf{1 4}$ have also been computed with the M06 density functional ${ }^{15,16}$ to ensure that results are not functional dependent. Despite small differences on the energy profiles, the same conclusions are drawn with the two functionals (Table S4). In both cases, the main group elements are represented with the Pople's $6-31+\mathrm{G}(\mathrm{d}, \mathrm{p})$ basis sets $^{17,18}$ and Vanadium is described with the all-electron Wachters-Hay $6-311+\mathrm{G}(\mathrm{d}, \mathrm{p})$ basis sets. ${ }^{19}$, ${ }^{20}$ The nature of all stationary points is verified by vibrational analysis and the nature of minima connected by each transition states is determined either by IRC calculations or geometry optimizations using as starting point the structure of the transition state displaced \pm 0.1 times the vector of the imaginary frequency. Solvent effects are included through single point calculations at the gas phase optimized geometry using the SMD continuum model ${ }^{21}$ and benzene as solvent. Thermal corrections are obtained at $298.15 \mathrm{~K}$ and $1 \mathrm{~atm}$ in gas phase, the Gibbs energy values reported along the manuscript being computed as $\Delta G_{298}^{0}=G_{g p}^{0}+\Delta G_{s o l v}^{0}$. No transition states are found for the ligand coordination and decoordination steps. Thus, coordination and decoordination energy barriers are supposed to be diffusion controlled and estimated from $\Delta G^{\ddagger}=R T \ln \left(8 N_{A} h / 3 \eta\right)$, where $\mathrm{N}_{\mathrm{A}}$ is the Avogadro number, $\mathrm{h}$ is the Plank constant and $\eta$ the solvent viscosity. ${ }^{22,23}$ The ${ }^{13} \mathrm{C}$ NMR chemical shifts of the metallacyclobutane carbon atoms are computed at the same level of theory using the GIAO method ${ }^{24}$ to analyze the electronic structure of the distorted TBP metallacycle found for the vanadium oxo. 
Table S4. B3LYP-D3 and M06 Relative Gibbs energies (in kcal $\mathrm{mol}^{-1}$ ) with respect to $\mathbf{I}_{\mathbf{H}}+$ ethene for all intermediates and transition states of the $\mathbf{5 b}$ and $\mathbf{1 4}$ precursor deactivation through bhydride elimination.

\begin{tabular}{lcccc}
\hline & \multicolumn{2}{c}{$5 \mathbf{b}$} & \multicolumn{2}{c}{$\mathbf{1 4}$} \\
\cline { 2 - 5 } Species & B3LYP & M06 & B3LYP & M06 \\
\hline $\mathbf{I H}_{\mathbf{H}}$ & 0.0 & 0.0 & 0.0 & 0.0 \\
TS(IH-IIIH) & 8.3 & 5.5 & 9.7 & 6.4 \\
IIIH-H & -0.3 & -4.6 & -0.4 & -6.4 \\
TS(IIIH-H-III'H-H) & N.A. & N.A. & 6.2 & 1.6 \\
AH-H & -1.0 & -3.0 & -0.5 & -4.2 \\
TS(AH-H-BH-H) & 21.3 & 15.7 & 29.2 & 23.9 \\
BH-H $_{\text {TS(B-H-CH-H) }}$ & -1.1 & -5.4 & -1.8 & -6.2 \\
${ }^{\mathbf{1}} \mathbf{C}_{\mathbf{H}-\mathbf{H}}$ & -0.4 & N.A. & -0.9 & -5.0 \\
${ }^{\mathbf{3}} \mathbf{C H}_{\mathbf{H}-\mathbf{H}}$ & -4.0 & -5.0 & -25.7 & -27.5 \\
\hline
\end{tabular}

Table S5. Calculated ${ }^{13} \mathrm{C}$ NMR chemical shifts (ppm) for 14-III and 14-A species involved in the RCM of 17 catalyzed by syn-14.

\begin{tabular}{lccc}
\hline Species & $\mathrm{Ca}$ & $\mathrm{Cb}$ & $\mathrm{Ca}$ \\
\hline syn-14-III'TMS-DTSA & 121.7 & 6.3 & 135.6 \\
anti-IIITMS-DTSA & 117.9 & 9.0 & 137.8 \\
syn-III'DTSA-H & 148.1 & 22.5 & 94.7 \\
anti-III'DTSA-H & 122.9 & 13.8 & 105.4 \\
syn-IIIH-DTSA & 128.4 & 5.4 & 99.7 \\
anti-IIIH-DTSA & 115.5 & 2.2 & 95.8 \\
IIIH-H & 102.2 & 1.1 & 99.9 \\
\hline syn-ATMS-DTSA & 36.5 & 26.4 & 66.4 \\
anti-ATMS-DTSA & 38.8 & 27.6 & 69.9 \\
syn-ADTSA-H & 46.8 & 40.3 & 39.6 \\
anti-ADTSA-H & 34.5 & 39.1 & 43.4 \\
syn-AH-DTSA & 40.1 & 32.4 & 50.2 \\
anti-AH-DTSA & 37.8 & 26.9 & 46.6 \\
AH-H & 32.8 & 26.1 & 46.9 \\
\hline
\end{tabular}




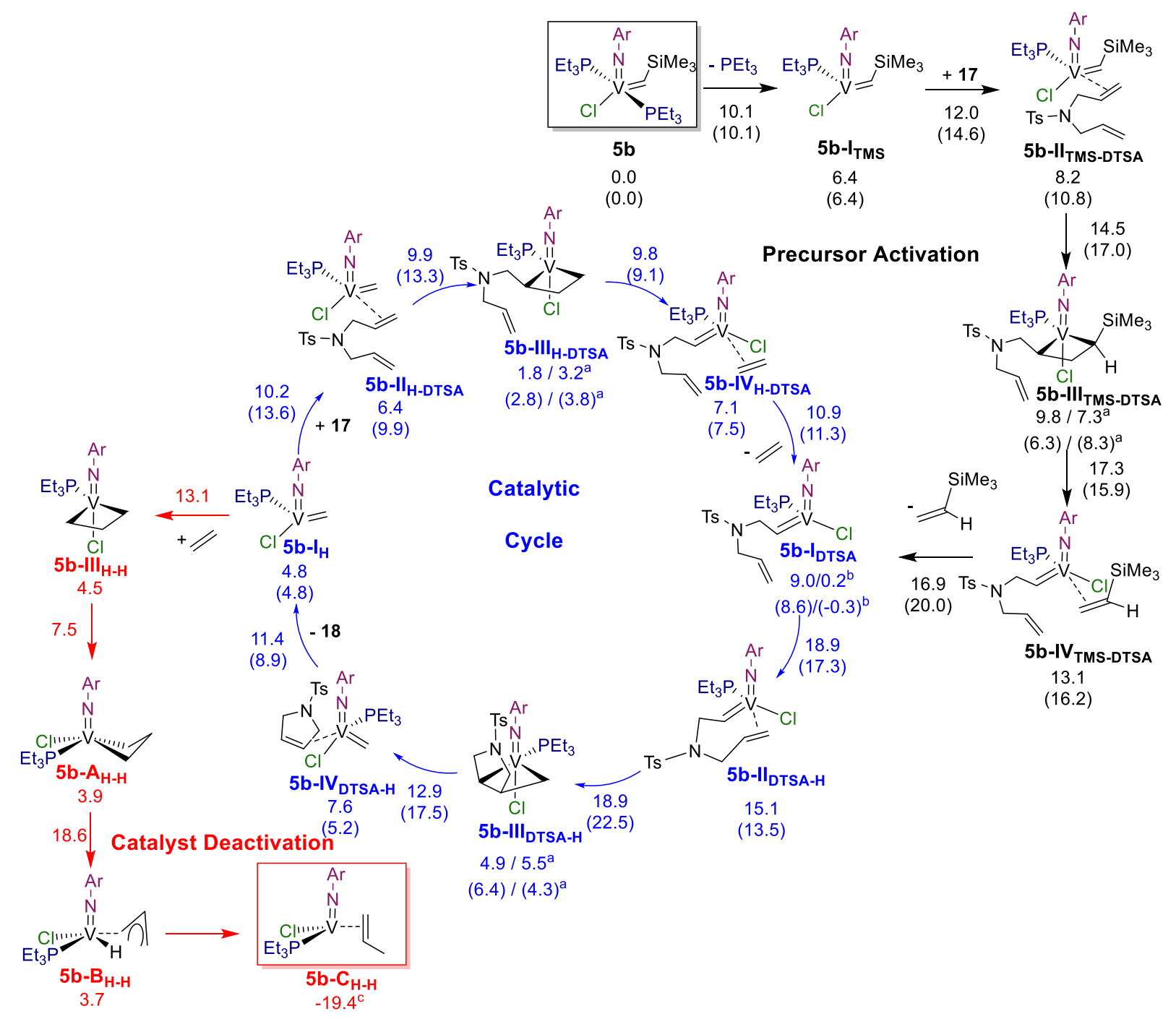

Figure S2. Relative Gibbs energies (in $\mathrm{kcal} \mathrm{mol}^{-1}$ ) with respect to the initial precursor and two $\mathbf{1 7}$ molecules of the $\mathbf{1 7}$ RCM process catalyzed by syn-5b. Two relative carbene - incoming olefin orientations have been considered: all substituents pointing toward the oxo ligand and (substituents pointing towards opposite directions). Values over the arrows correspond to the Gibbs energies of the transition states. ${ }^{a}$ The second values corresponds to the SP metallacyclobutane isomer. ${ }^{\mathrm{b}}$ The first the value involves 14-IDTSA and $\mathbf{1 7}$ and the second value implies $\mathbf{5 b}$-IDTSA, $\mathbf{1 8}$ and ethylene. ${ }^{\mathrm{c}}$ The ground state of this structure is a triplet. 


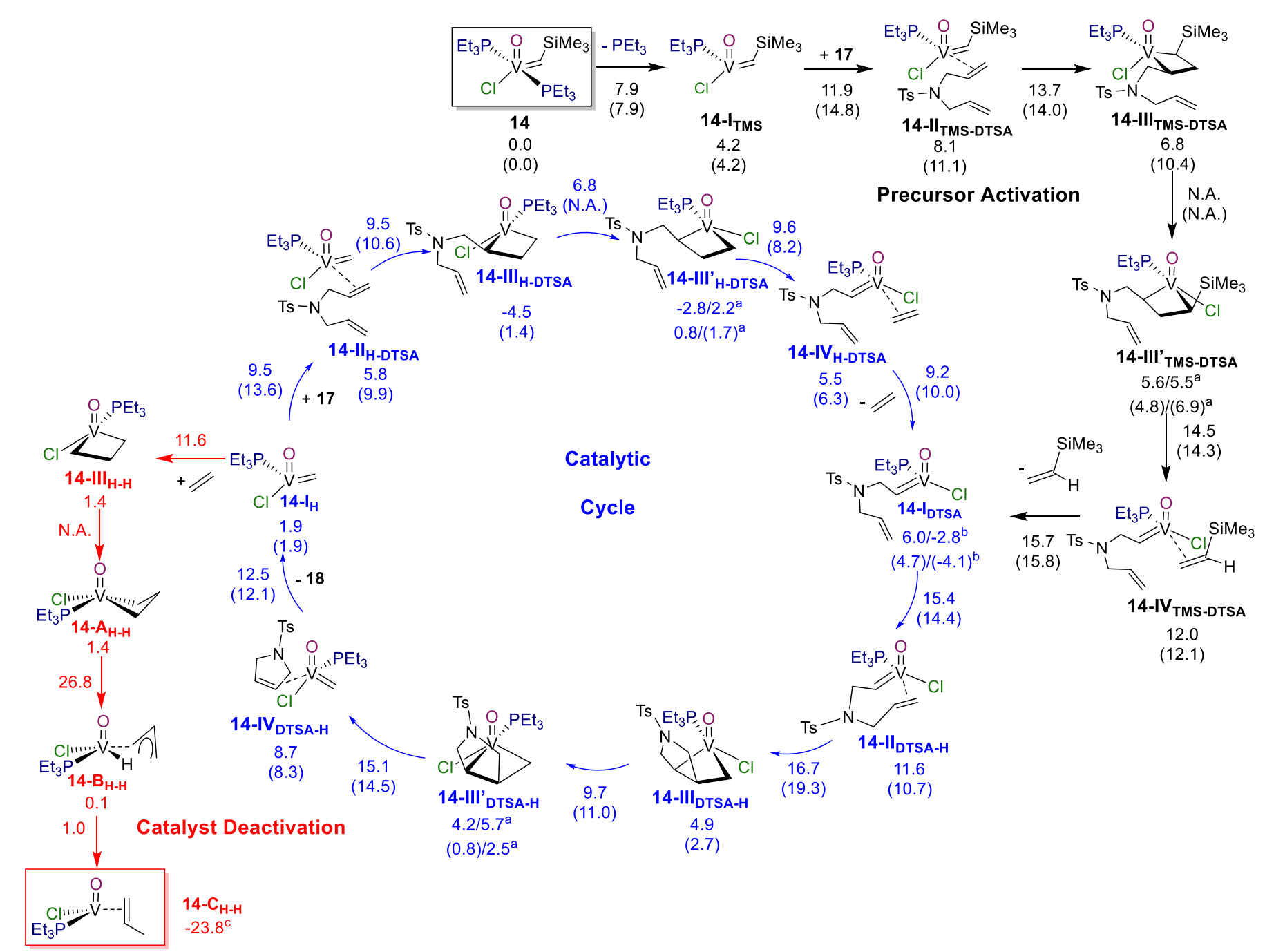

Figure S3. Relative Gibbs energies (in $\mathrm{kcal} \mathrm{mol}^{-1}$ ) with respect to the initial precursor and two $\mathbf{1 7}$ molecules of the $\mathbf{1 7}$ RCM process catalyzed by syn-14. Two relative carbene - incoming olefin orientations have been considered: all substituents pointing toward the oxo ligand and (substituents pointing towards opposite directions). Values over the arrows correspond to the Gibbs energies of the transition states. ${ }^{a}$ The second values corresponds to the SP metallacyclobutane isomer.

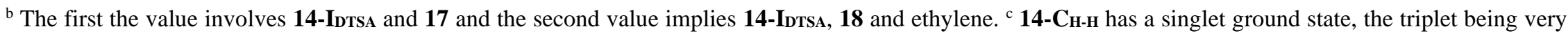
similar in energy 


\section{X-Ray structural studies}

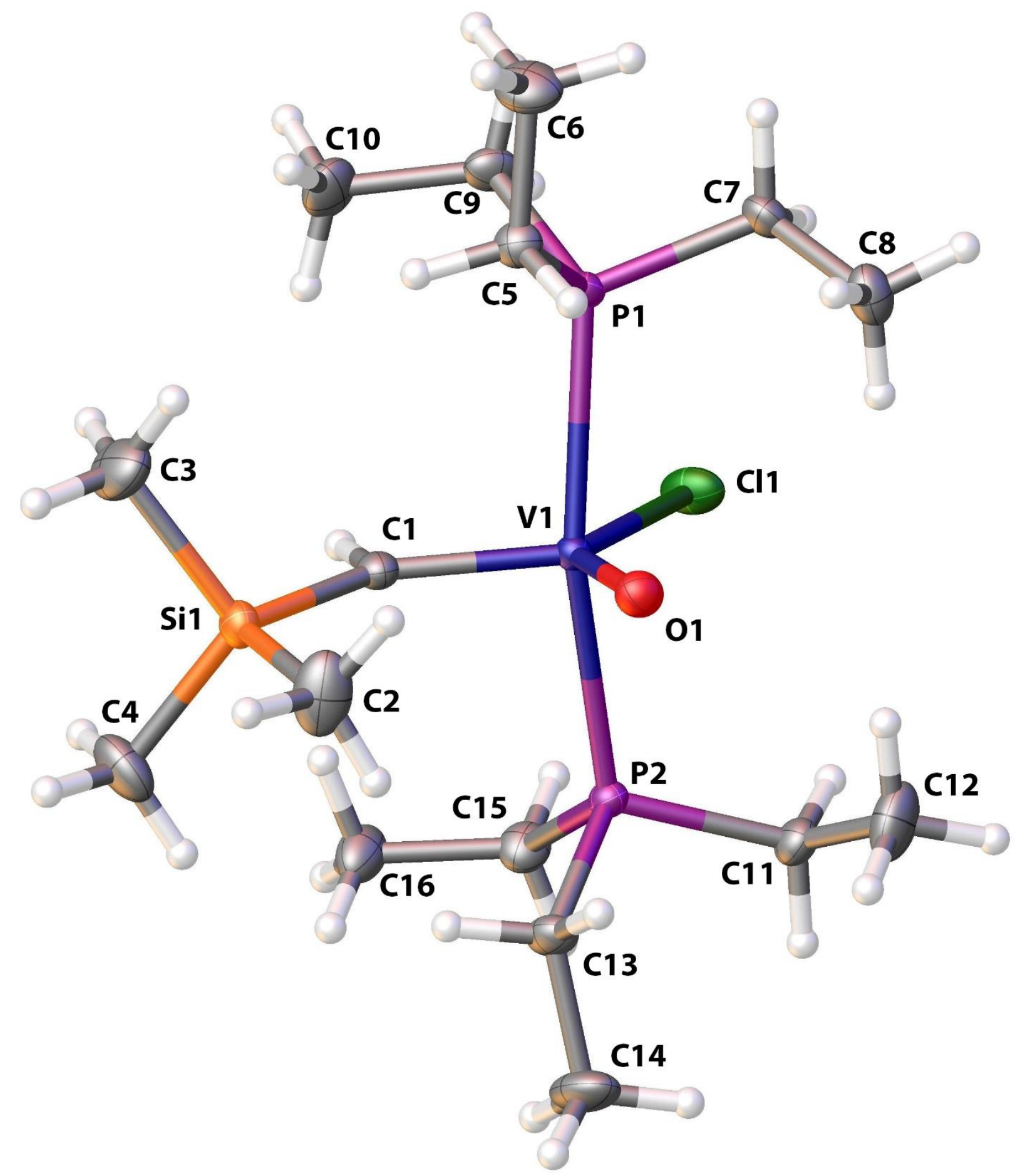

Figure S4. Molecular structure of 14 (CCDC 2092938). Atomic displacement ellipsoids are drawn at the 50\% probability level. 


\section{Crystal data}

$$
\begin{aligned}
& \mathrm{C}_{16} \mathrm{H}_{40} \mathrm{ClOp} 2 \mathrm{SiV} \\
& M_{r}=424.90 \\
& \text { Monoclinic, } C 2 / c \\
& a=24.305(6) \AA \\
& b=10.012(2) \AA \\
& c=19.836(5) \AA \\
& \beta=100.349(5)^{\circ} \\
& V=4748(2) \AA^{3} \\
& Z=8
\end{aligned}
$$

\section{Data collection}

\author{
Bruker D8 Quest PHOTON II \\ diffractometer \\ $\omega$-scan \\ Absorption correction: multi-scan \\ SADABS 2016/2: Krause, L., Herbst-Irmer, R., \\ Sheldrick G.M. \& Stalke D., J. Appl. Cryst. 48 (2015) \\ 3-10
}

$T_{\min }=0.606, T_{\max }=0.745$

\section{Refinement}

Refinement on $F^{2}$

Least-squares matrix: full

$R\left[F^{2}>2 \sigma\left(F^{2}\right)\right]=0.029$

$w R\left(F^{2}\right)=0.084$

$S=1.10$

4873 reflections

212 parameters

0 restraints

Primary atom site location: dual
$F(000)=1824$

$D_{\mathrm{x}}=1.189 \mathrm{Mg} \mathrm{m}^{-3}$

Mo $K \alpha$ radiation, $\lambda=0.71073 \AA$

Cell parameters from 9981 reflections

$\theta=2.9-25.4^{\circ}$

$\mu=0.72 \mathrm{~mm}-1$

$T=144 \mathrm{~K}$

Block

$0.30 \times 0.25 \times 0.17 \mathrm{~mm}$
23573 measured reflections 4873 independent reflections 4727 reflections with $I>2 \sigma(I)$

$R_{\text {int }}=0.038$

$\theta_{\max }=26.4^{\circ}, \theta_{\min }=2.5^{\circ}$

$h=-30 \rightarrow 30$

$k=-12 \rightarrow 12$

$l=-24 \rightarrow 24$

\section{Special details}

Geometry. All e.s.d.'s (except the e.s.d. in the dihedral angle between two l.s. planes) are estimated using the full covariance matrix. The cell e.s.d.'s are taken into account individually in the estimation of e.s.d.'s in distances, angles and torsion angles; correlations between e.s.d.'s in cell parameters are only used when they are defined by crystal symmetry. An approximate (isotropic) treatment of cell e.s.d.'s is used for estimating e.s.d.'s involving l.s. planes.

\section{References}

Dolomanov, O. V., Bourhis, L. J., Gildea, R. J., Howard, J. A. K. \& Puschmann, H. (2009). J. Appl. Cryst. 42, $339-341$.

Sheldrick, G. M. (2015). Acta Cryst. A71, 3-8.

Sheldrick, G. M. (2015). Acta Cryst. C71, 3-8.

\section{Computing details}

Data collection: Bruker APEX3; cell refinement: SAINT V8.40B (2016); data reduction: SAINT V8.40B (2016);

program(s) used to solve structure: SHELXT 2018/2 (Sheldrick, 2018); program(s) used to refine structure: SHELXL 2018/3 (Sheldrick, 2015); molecular graphics: Olex2 1.3 (Dolomanov et al., 2009); software used to prepare material for publication: Olex2 1.3 (Dolomanov et al., 2009). 
Fractional atomic coordinates and isotropic or equivalent isotropic displacement parameters $\left(\AA^{2}\right)$

\begin{tabular}{|c|c|c|c|c|}
\hline & $x$ & $y$ & $z$ & $U_{\text {iso }} * / U_{\text {eq }}$ \\
\hline V1 & $0.63016(2)$ & $0.25129(2)$ & $0.71877(2)$ & $0.01411(8)$ \\
\hline $\mathrm{P} 2$ & $0.62547(2)$ & $0.22894(4)$ & $0.84265(2)$ & $0.01604(10)$ \\
\hline $\mathrm{P} 1$ & $0.64690(2)$ & $0.21535(4)$ & $0.60082(2)$ & $0.01563(10)$ \\
\hline $\mathrm{Cl1}$ & $0.69298(2)$ & $0.06856(4)$ & $0.74265(2)$ & 0.02791 (11) \\
\hline Si1 & $0.62388(2)$ & $0.59651(4)$ & $0.70428(2)$ & $0.02001(11)$ \\
\hline $\mathrm{O} 1$ & $0.56327(5)$ & $0.25168(10)$ & $0.69445(6)$ & $0.0214(2)$ \\
\hline $\mathrm{C} 1$ & $0.65303(7)$ & $0.42709(14)$ & $0.72238(7)$ & 0.0187 (3) \\
\hline C15 & $0.71798(7)$ & $0.23536(16)$ & $0.58412(9)$ & $0.0248(3)$ \\
\hline $\mathrm{H} 15 \mathrm{~A}$ & 0.743293 & 0.177545 & 0.616301 & $0.030 *$ \\
\hline H15B & 0.718903 & 0.203292 & 0.537124 & $0.030 *$ \\
\hline $\mathrm{C} 7$ & $0.60480(7)$ & $0.06244(15)$ & $0.86673(8)$ & $0.0221(3)$ \\
\hline H7A & 0.635223 & -0.001355 & 0.863001 & $0.027 *$ \\
\hline H7B & 0.599932 & 0.064136 & 0.915220 & $0.027 *$ \\
\hline C9 & $0.57335(6)$ & $0.34200(16)$ & $0.86703(8)$ & $0.0212(3)$ \\
\hline H9A & 0.584952 & 0.434750 & 0.859399 & $0.025^{*}$ \\
\hline H9B & 0.537398 & 0.326215 & 0.835673 & $0.025^{*}$ \\
\hline $\mathrm{C} 13$ & $0.63084(7)$ & $0.04533(15)$ & $0.56955(8)$ & $0.0227(3)$ \\
\hline H13A & 0.636926 & 0.039281 & 0.521612 & $0.027^{*}$ \\
\hline H13B & 0.657153 & -0.017293 & 0.597386 & $0.027 *$ \\
\hline $\mathrm{C} 5$ & $0.68934(7)$ & $0.25424(16)$ & $0.90627(8)$ & $0.0240(3)$ \\
\hline H5A & 0.681079 & 0.233798 & 0.952258 & $0.029 *$ \\
\hline H5B & 0.717974 & 0.189807 & 0.897020 & $0.029 *$ \\
\hline $\mathrm{C} 8$ & $0.55104(7)$ & $0.01317(17)$ & $0.82265(9)$ & $0.0283(4)$ \\
\hline H8A & 0.556170 & 0.006451 & 0.774885 & $0.042 *$ \\
\hline H8B & 0.520732 & 0.076141 & 0.825796 & $0.042 *$ \\
\hline $\mathrm{H} 8 \mathrm{C}$ & 0.541510 & -0.074880 & 0.838827 & $0.042 *$ \\
\hline $\mathrm{C} 11$ & $0.60281(7)$ & $0.32225(16)$ & $0.53874(8)$ & $0.0246(3)$ \\
\hline H11A & 0.563627 & 0.312011 & 0.545413 & $0.030^{*}$ \\
\hline H11B & 0.613725 & 0.416240 & 0.549352 & $0.030 *$ \\
\hline $\mathrm{C} 10$ & $0.56295(8)$ & $0.3316(2)$ & $0.94060(9)$ & $0.0336(4)$ \\
\hline $\mathrm{H} 10 \mathrm{~A}$ & 0.547096 & 0.243775 & 0.947612 & $0.050 *$ \\
\hline $\mathrm{H} 10 \mathrm{~B}$ & 0.536709 & 0.401536 & 0.948765 & $0.050 *$ \\
\hline $\mathrm{H} 10 \mathrm{C}$ & 0.598383 & 0.342843 & 0.972574 & $0.050 *$ \\
\hline C6 & $0.71374(8)$ & 0.39445 (19) & $0.90749(10)$ & 0.0337 (4) \\
\hline H6A & 0.723061 & 0.415131 & 0.862575 & $0.050 *$ \\
\hline H6B & 0.747647 & 0.399399 & 0.942604 & $0.050^{*}$ \\
\hline $\mathrm{H} 6 \mathrm{C}$ & 0.686232 & 0.459087 & 0.918076 & $0.050 *$ \\
\hline C16 & $0.74058(8)$ & $0.37769(18)$ & $0.59089(10)$ & $0.0321(4)$ \\
\hline $\mathrm{H} 16 \mathrm{~A}$ & 0.718075 & 0.434447 & 0.556196 & $0.048^{*}$ \\
\hline H16B & 0.779547 & 0.378060 & 0.584168 & $0.048^{*}$ \\
\hline $\mathrm{H} 16 \mathrm{C}$ & 0.738634 & 0.412064 & 0.636663 & $0.048^{*}$ \\
\hline $\mathrm{C} 4$ & $0.66223(9)$ & $0.68463(19)$ & $0.64367(11)$ & $0.0386(4)$ \\
\hline $\mathrm{H} 4 \mathrm{~A}$ & 0.702029 & 0.690215 & 0.663880 & $0.058 *$ \\
\hline $\mathrm{H} 4 \mathrm{~B}$ & 0.647010 & 0.774886 & 0.634903 & $0.058^{*}$ \\
\hline $\mathrm{H} 4 \mathrm{C}$ & 0.657742 & 0.634987 & 0.600445 & $0.058^{*}$ \\
\hline C3 & $0.54825(8)$ & $0.5894(2)$ & $0.66571(13)$ & $0.0444(5)$ \\
\hline $\mathrm{H} 3 \mathrm{~A}$ & 0.543671 & 0.545884 & 0.620788 & $0.067 *$ \\
\hline H3B & 0.533116 & 0.680268 & 0.660257 & $0.067 *$ \\
\hline $\mathrm{H} 3 \mathrm{C}$ & 0.528155 & 0.538307 & 0.695760 & $0.067^{*}$ \\
\hline C14 & $0.57155(8)$ & $0.0021(2)$ & $0.57219(12)$ & $0.0403(5)$ \\
\hline $\mathrm{H} 14 \mathrm{~A}$ & 0.545197 & 0.058645 & 0.541537 & $0.060 *$ \\
\hline H14B & 0.564654 & 0.010990 & 0.619171 & $0.060 *$ \\
\hline $\mathrm{H} 14 \mathrm{C}$ & 0.566428 & -0.091260 & 0.557586 & $0.060^{*}$ \\
\hline $\mathrm{C} 12$ & $0.60456(10)$ & $0.2972(2)$ & $0.46323(9)$ & $0.0393(5)$ \\
\hline $\mathrm{H} 12 \mathrm{~A}$ & 0.579628 & 0.360315 & 0.434886 & $0.059^{*}$ \\
\hline $\mathrm{H} 12 \mathrm{~B}$ & 0.592314 & 0.205644 & 0.451122 & $0.059 *$ \\
\hline $\mathrm{H} 12 \mathrm{C}$ & 0.642863 & 0.309484 & 0.455207 & $0.059 *$ \\
\hline $\mathrm{C} 2$ & $0.63282(10)$ & $0.6973(2)$ & $0.78472(10)$ & $0.0436(5)$ \\
\hline $\mathrm{H} 2 \mathrm{~A}$ & 0.608110 & 0.662415 & 0.814543 & $0.065^{*}$ \\
\hline $\mathrm{H} 2 \mathrm{~B}$ & 0.623285 & 0.790730 & 0.773387 & $0.065^{*}$ \\
\hline
\end{tabular}




\begin{tabular}{|c|c|c|c|c|}
\hline $\mathrm{H} 2 \mathrm{C}$ & 0.671761 & 0.691672 & 0.808446 & $0.065^{*}$ \\
\hline H1 & $0.6944(9)$ & $0.422(2)$ & $0.7364(11)$ & $0.034(6) *$ \\
\hline
\end{tabular}

\begin{tabular}{|c|c|c|c|c|c|c|}
\hline & $U^{11}$ & $U^{22}$ & $U^{33}$ & $U^{12}$ & $U^{13}$ & $U^{23}$ \\
\hline V1 & $0.01648(14)$ & $0.01263(13)$ & $0.01309(14)$ & $0.00080(8)$ & $0.00232(10)$ & $0.00103(8)$ \\
\hline $\mathrm{P} 2$ & $0.01729(18)$ & $0.01634(18)$ & $0.01412(18)$ & $0.00073(13)$ & 0.00179 (14) & $0.00176(13)$ \\
\hline $\mathrm{P} 1$ & $0.01874(18)$ & $0.01442(18)$ & $0.01365(18)$ & $0.00057(13)$ & $0.00272(14)$ & -0.00068 \\
\hline $\mathrm{Cl1}$ & $0.0342(2)$ & $0.0270(2)$ & 0.02202 (19) & $0.01546(15)$ & $0.00370(16)$ & $0.00393(14)$ \\
\hline Sil & $0.0235(2)$ & 0.01395 (19) & $0.0225(2)$ & $-0.00007(15)$ & 0.00377 (17) & $-0.00013(16)$ \\
\hline O1 & $0.0205(5)$ & $0.0229(6)$ & $0.0208(6)$ & -0.0008 & $0.0037(4)$ & $0.0016(4)$ \\
\hline $\mathrm{C} 1$ & $0.0231(7)$ & $0.0170(7)$ & $0.0160(7)$ & $-0.0007(5)$ & $0.0036(6)$ & $-0.0004(5)$ \\
\hline $\mathrm{C} 15$ & $0.0226(8)$ & $0.0269(8)$ & $0.0268(8)$ & $-0.0011(6)$ & $0.0095(6)$ & $-0.0045(6)$ \\
\hline $\mathrm{C} 7$ & $0.0264(8)$ & $0.0189(7)$ & $0.0206(7)$ & $0.0002(6)$ & $0.0028(6)$ & $0.0060(6)$ \\
\hline C9 & $0.0206(7)$ & $0.0213(7)$ & $0.0222(7)$ & $0.0026(6)$ & $0.0052(6)$ & $0.0002(6)$ \\
\hline $\mathrm{C} 13$ & $0.0281(8)$ & $0.0180(7)$ & $0.0214(7)$ & $0.0000(6)$ & $0.0029(6)$ & $-0.0043(6)$ \\
\hline $\mathrm{C} 5$ & $0.0209(7)$ & $0.0302(8)$ & $0.0192(8)$ & $0.0005(6)$ & $-0.0011(6)$ & $0.0023(6)$ \\
\hline $\mathrm{C} 8$ & $0.0250(8)$ & $0.0222(8)$ & $0.0370(9)$ & $-0.0037(6)$ & $0.0039(7)$ & $0.0042(7)$ \\
\hline $\mathrm{C} 11$ & $0.0320(8)$ & $0.0218(7)$ & $0.0185(7)$ & $0.0054(6)$ & $0.0005(6)$ & $0.0021(6)$ \\
\hline $\mathrm{C} 10$ & $0.0375(9)$ & $0.0407(10)$ & $0.0264(9)$ & $0.0055(8)$ & $0.0164(7)$ & $-0.0003(7)$ \\
\hline C6 & $0.0299(9)$ & $0.0364(10)$ & $0.0310(9)$ & $-0.0087(7)$ & $-0.0043(7)$ & $-0.0038(8)$ \\
\hline $\mathrm{C} 16$ & $0.0319(9)$ & $0.0333(9)$ & $0.0341(9)$ & $-0.0122(7)$ & $0.0137(7)$ & -0.0080 \\
\hline $\mathrm{C} 4$ & 0.0464 (11) & $0.0259(9)$ & 0.0468 (11) & $0.0034(8)$ & $0.0176(9)$ & $0.0148(8)$ \\
\hline $\mathrm{C} 3$ & $0.0270(9)$ & 0.0309 (10) & 0.0708 (15) & $0.0052(7)$ & $-0.0036(9)$ & $-0.0026(9)$ \\
\hline C14 & $0.0311(9)$ & $0.0320(9)$ & $0.0572(13)$ & $-0.0100(8)$ & $0.0060(9)$ & -0.0159 (9) \\
\hline $\mathrm{C} 12$ & $0.0625(13)$ & $0.0353(10)$ & $0.0173(8)$ & $0.0105(9)$ & $0.0001(8)$ & $0.0029(7)$ \\
\hline $\mathrm{C} 2$ & $0.0686(14)$ & $0.0251(9)$ & $0.0352(10)$ & $0.0063(9)$ & $0.0045(10)$ & $-0.0089(8)$ \\
\hline
\end{tabular}

Geometric parameters $\left(\AA,^{\circ}\right)$

$\begin{array}{ll}\text { V1-P2 } & 2.4903(7) \\ \text { V1-P1 } & 2.4722(7) \\ \text { V1-C11 } & 2.3754(6) \\ \text { V1-O1 } & 1.6107(12) \\ \text { V1-C1 } & 1.8432(15) \\ \text { P2-C7 } & 1.8291(16) \\ \text { P2-C9 } & 1.8277(16) \\ \text { P2-C5 } & 1.8337(16) \\ \text { P1-C15 } & 1.8274(17) \\ \text { P1-C13 } & 1.8296(16) \\ \text { P1-C11 } & 1.8266(15) \\ \text { Si1-C1 } & 1.8484(16) \\ \text { Si1-C4 } & 1.8695(19) \\ \text { Si1-C3 } & 1.861(2) \\ \text { Si1-C2 } & 1.8674(19) \\ \text { C1-H1 } & 1.00(2) \\ \text { C15-H15A } & 0.9900 \\ \text { C15-H15B } & 0.9900 \\ \text { C15-C16 } & 1.524(2) \\ \text { C7-H7A } & 0.9900 \\ \text { C7-H7B } & 0.9900 \\ \text { C7-C8 } & 1.518(2) \\ \text { C9-H9A } & 0.9900 \\ \text { C9-H9B } & 0.9900 \\ \text { C9-C10 } & 1.529(2) \\ \text { C13-H13A } & 0.9900 \\ \text { C13-H13B } & 0.9900 \\ \text { C13-C14 } & 1.515(2) \\ \text { C5-H5A } & 0.9900 \\ \text { C5-H5B } & 0.9900 \\ \text { C5-C6 } & 1.522(2) \\ & \\ & \end{array}$

$\begin{array}{ll}\text { C8-H8A } & 0.9800 \\ \text { C8-H8B } & 0.9800 \\ \text { C8-H8C } & 0.9800 \\ \text { C11-H11A } & 0.9900 \\ \text { C11-H11B } & 0.9900 \\ \text { C11-C12 } & 1.527(2) \\ \text { C10-H10A } & 0.9800 \\ \text { C10-H10B } & 0.9800 \\ \text { C10-H10C } & 0.9800 \\ \text { C6-H6A } & 0.9800 \\ \text { C6-H6B } & 0.9800 \\ \text { C6-H6C } & 0.9800 \\ \text { C16-H16A } & 0.9800 \\ \text { C16-H16B } & 0.9800 \\ \text { C16-H16C } & 0.9800 \\ \text { C4-H4A } & 0.9800 \\ \text { C4-H4B } & 0.9800 \\ \text { C4-H4C } & 0.9800 \\ \text { C3-H3A } & 0.9800 \\ \text { C3-H3B } & 0.9800 \\ \text { C3-H3C } & 0.9800 \\ \text { C14-H14A } & 0.9800 \\ \text { C14-H14B } & 0.9800 \\ \text { C14-H14C } & 0.9800 \\ \text { C12-H12A } & 0.9800 \\ \text { C12-H12B } & 0.9800 \\ \text { C12-H12C } & 0.9800 \\ \text { C2-H2A } & 0.9800 \\ \text { C2-H2B } & 0.9800 \\ \text { C2-H2C } & 0.9800 \\ \end{array}$




\begin{tabular}{|c|c|}
\hline $\mathrm{P} 1-\mathrm{V} 1-\mathrm{P} 2$ & $164.855(17)$ \\
\hline $\mathrm{C} 11-\mathrm{V} 1-\mathrm{P} 2$ & $82.862(15)$ \\
\hline $\mathrm{C} 11-\mathrm{V} 1-\mathrm{P} 1$ & $82.382(16)$ \\
\hline $\mathrm{O} 1-\mathrm{V} 1-\mathrm{P} 2$ & $94.20(4)$ \\
\hline $\mathrm{O} 1-\mathrm{V} 1-\mathrm{P} 1$ & $92.62(4)$ \\
\hline $\mathrm{O} 1-\mathrm{V} 1-\mathrm{Cl} 1$ & $129.76(4)$ \\
\hline $\mathrm{O} 1-\mathrm{V} 1-\mathrm{C} 1$ & $106.89(6)$ \\
\hline $\mathrm{C} 1-\mathrm{V} 1-\mathrm{P} 2$ & $96.57(5)$ \\
\hline $\mathrm{C} 1-\mathrm{V} 1-\mathrm{P} 1$ & $94.36(5)$ \\
\hline $\mathrm{C} 1-\mathrm{V} 1-\mathrm{Cl} 1$ & $123.31(5)$ \\
\hline $\mathrm{C} 7-\mathrm{P} 2-\mathrm{V} 1$ & $113.77(5)$ \\
\hline $\mathrm{C} 7-\mathrm{P} 2-\mathrm{C} 5$ & $100.63(7)$ \\
\hline $\mathrm{C} 9-\mathrm{P} 2-\mathrm{V} 1$ & $111.24(5)$ \\
\hline $\mathrm{C} 9-\mathrm{P} 2-\mathrm{C} 7$ & $105.03(8)$ \\
\hline $\mathrm{C} 9-\mathrm{P} 2-\mathrm{C} 5$ & $105.88(8)$ \\
\hline $\mathrm{C} 5-\mathrm{P} 2-\mathrm{V} 1$ & $118.91(6)$ \\
\hline $\mathrm{C} 15-\mathrm{P} 1-\mathrm{V} 1$ & $118.51(6)$ \\
\hline $\mathrm{C} 15-\mathrm{P} 1-\mathrm{C} 13$ & $101.05(7)$ \\
\hline $\mathrm{C} 13-\mathrm{P} 1-\mathrm{V} 1$ & $113.26(5)$ \\
\hline $\mathrm{C} 11-\mathrm{P} 1-\mathrm{V} 1$ & $112.11(6)$ \\
\hline $\mathrm{C} 11-\mathrm{P} 1-\mathrm{C} 15$ & $105.83(8)$ \\
\hline $\mathrm{C} 11-\mathrm{P} 1-\mathrm{C} 13$ & $104.65(7)$ \\
\hline $\mathrm{C} 1-\mathrm{Si} 1-\mathrm{C} 4$ & $109.88(8)$ \\
\hline $\mathrm{C} 1-\mathrm{Si} 1-\mathrm{C} 3$ & $111.13(8)$ \\
\hline $\mathrm{C} 1-\mathrm{Si} 1-\mathrm{C} 2$ & $110.38(8)$ \\
\hline $\mathrm{C} 3-\mathrm{Si} 1-\mathrm{C} 4$ & $108.86(11)$ \\
\hline $\mathrm{C} 3-\mathrm{Si} 1-\mathrm{C} 2$ & $109.07(11)$ \\
\hline $\mathrm{C} 2-\mathrm{Si} 1-\mathrm{C} 4$ & $107.43(11)$ \\
\hline $\mathrm{V} 1-\mathrm{C} 1-\mathrm{Si} 1$ & $140.03(9)$ \\
\hline $\mathrm{V} 1-\mathrm{C} 1-\mathrm{H} 1$ & $104.3(12)$ \\
\hline $\mathrm{Si} 1-\mathrm{C} 1-\mathrm{H} 1$ & $115.6(12)$ \\
\hline $\mathrm{P} 1-\mathrm{C} 15-\mathrm{H} 15 \mathrm{~A}$ & 108.5 \\
\hline $\mathrm{P} 1-\mathrm{C} 15-\mathrm{H} 15 \mathrm{~B}$ & 108.5 \\
\hline $\mathrm{H} 15 \mathrm{~A}-\mathrm{C} 15-\mathrm{H} 15 \mathrm{~B}$ & 107.5 \\
\hline $\mathrm{C} 16-\mathrm{C} 15-\mathrm{P} 1$ & $115.08(12)$ \\
\hline $\mathrm{C} 16-\mathrm{C} 15-\mathrm{H} 15 \mathrm{~A}$ & 108.5 \\
\hline $\mathrm{C} 16-\mathrm{C} 15-\mathrm{H} 15 \mathrm{~B}$ & 108.5 \\
\hline $\mathrm{P} 2-\mathrm{C} 7-\mathrm{H} 7 \mathrm{~A}$ & 108.9 \\
\hline $\mathrm{P} 2-\mathrm{C} 7-\mathrm{H} 7 \mathrm{~B}$ & 108.9 \\
\hline $\mathrm{H} 7 \mathrm{~A}-\mathrm{C} 7-\mathrm{H} 7 \mathrm{~B}$ & 107.7 \\
\hline $\mathrm{C} 8-\mathrm{C} 7-\mathrm{P} 2$ & $113.21(11)$ \\
\hline $\mathrm{C} 8-\mathrm{C} 7-\mathrm{H} 7 \mathrm{~A}$ & 108.9 \\
\hline $\mathrm{C} 8-\mathrm{C} 7-\mathrm{H} 7 \mathrm{~B}$ & 108.9 \\
\hline $\mathrm{P} 2-\mathrm{C} 9-\mathrm{H} 9 \mathrm{~A}$ & 108.1 \\
\hline $\mathrm{P} 2-\mathrm{C} 9-\mathrm{H} 9 \mathrm{~B}$ & 108.1 \\
\hline $\mathrm{H} 9 \mathrm{~A}-\mathrm{C} 9-\mathrm{H} 9 \mathrm{~B}$ & 107.3 \\
\hline $\mathrm{C} 10-\mathrm{C} 9-\mathrm{P} 2$ & $116.86(11)$ \\
\hline $\mathrm{C} 10-\mathrm{C} 9-\mathrm{H} 9 \mathrm{~A}$ & 108.1 \\
\hline $\mathrm{C} 10-\mathrm{C} 9-\mathrm{H} 9 \mathrm{~B}$ & 108.1 \\
\hline $\mathrm{P} 1-\mathrm{C} 13-\mathrm{H} 13 \mathrm{~A}$ & 108.8 \\
\hline $\mathrm{P} 1-\mathrm{C} 13-\mathrm{H} 13 \mathrm{~B}$ & 108.8 \\
\hline $\mathrm{H} 13 \mathrm{~A}-\mathrm{C} 13-\mathrm{H} 13 \mathrm{~B}$ & 107.7 \\
\hline $\mathrm{C} 14-\mathrm{C} 13-\mathrm{P} 1$ & $113.60(12)$ \\
\hline $\mathrm{C} 14-\mathrm{C} 13-\mathrm{H} 13 \mathrm{~A}$ & 108.8 \\
\hline $\mathrm{C} 14-\mathrm{C} 13-\mathrm{H} 13 \mathrm{~B}$ & 108.8 \\
\hline $\mathrm{P} 2-\mathrm{C} 5-\mathrm{H} 5 \mathrm{~A}$ & 108.6 \\
\hline $\mathrm{P} 2-\mathrm{C} 5-\mathrm{H} 5 \mathrm{~B}$ & 108.6 \\
\hline $\mathrm{H} 5 \mathrm{~A}-\mathrm{C} 5-\mathrm{H} 5 \mathrm{~B}$ & 107.6 \\
\hline $\mathrm{C} 6-\mathrm{C} 5-\mathrm{P} 2$ & $114.68(11)$ \\
\hline $\mathrm{C} 6-\mathrm{C} 5-\mathrm{H} 5 \mathrm{~A}$ & 108.6 \\
\hline $\mathrm{C} 6-\mathrm{C} 5-\mathrm{H} 5 \mathrm{~B}$ & 108.6 \\
\hline
\end{tabular}

\begin{tabular}{|c|c|}
\hline $\mathrm{C} 7-\mathrm{C} 8-\mathrm{H} 8 \mathrm{~A}$ & 109.5 \\
\hline $\mathrm{C} 7-\mathrm{C} 8-\mathrm{H} 8 \mathrm{~B}$ & 109.5 \\
\hline $\mathrm{C} 7-\mathrm{C} 8-\mathrm{H} 8 \mathrm{C}$ & 109.5 \\
\hline $\mathrm{H} 8 \mathrm{~A}-\mathrm{C} 8-\mathrm{H} 8 \mathrm{~B}$ & 109.5 \\
\hline $\mathrm{H} 8 \mathrm{~A}-\mathrm{C} 8-\mathrm{H} 8 \mathrm{C}$ & 109.5 \\
\hline $\mathrm{H} 8 \mathrm{~B}-\mathrm{C} 8-\mathrm{H} 8 \mathrm{C}$ & 109.5 \\
\hline $\mathrm{P} 1-\mathrm{C} 11-\mathrm{H} 11 \mathrm{~A}$ & 108.1 \\
\hline $\mathrm{P} 1-\mathrm{C} 11-\mathrm{H} 11 \mathrm{~B}$ & 108.1 \\
\hline $\mathrm{H} 11 \mathrm{~A}-\mathrm{C} 11-\mathrm{H} 11 \mathrm{~B}$ & 107.3 \\
\hline $\mathrm{C} 12-\mathrm{C} 11-\mathrm{P} 1$ & $116.65(12)$ \\
\hline $\mathrm{C} 12-\mathrm{C} 11-\mathrm{H} 11 \mathrm{~A}$ & 108.1 \\
\hline $\mathrm{C} 12-\mathrm{C} 11-\mathrm{H} 11 \mathrm{~B}$ & 108.1 \\
\hline $\mathrm{C} 9-\mathrm{C} 10-\mathrm{H} 10 \mathrm{~A}$ & 109.5 \\
\hline $\mathrm{C} 9-\mathrm{C} 10-\mathrm{H} 10 \mathrm{~B}$ & 109.5 \\
\hline $\mathrm{C} 9-\mathrm{C} 10-\mathrm{H} 10 \mathrm{C}$ & 109.5 \\
\hline $\mathrm{H} 10 \mathrm{~A}-\mathrm{C} 10-\mathrm{H} 10 \mathrm{~B}$ & 109.5 \\
\hline $\mathrm{H} 10 \mathrm{~A}-\mathrm{C} 10-\mathrm{H} 10 \mathrm{C}$ & 109.5 \\
\hline $\mathrm{H} 10 \mathrm{~B}-\mathrm{C} 10-\mathrm{H} 10 \mathrm{C}$ & 109.5 \\
\hline $\mathrm{C} 5-\mathrm{C} 6-\mathrm{H} 6 \mathrm{~A}$ & 109.5 \\
\hline $\mathrm{C} 5-\mathrm{C} 6-\mathrm{H} 6 \mathrm{~B}$ & 109.5 \\
\hline $\mathrm{C} 5-\mathrm{C} 6-\mathrm{H} 6 \mathrm{C}$ & 109.5 \\
\hline $\mathrm{H} 6 \mathrm{~A}-\mathrm{C} 6-\mathrm{H} 6 \mathrm{~B}$ & 109.5 \\
\hline $\mathrm{H} 6 \mathrm{~A}-\mathrm{C} 6-\mathrm{H} 6 \mathrm{C}$ & 109.5 \\
\hline $\mathrm{H} 6 \mathrm{~B}-\mathrm{C} 6-\mathrm{H} 6 \mathrm{C}$ & 109.5 \\
\hline $\mathrm{C} 15-\mathrm{C} 16-\mathrm{H} 16 \mathrm{~A}$ & 109.5 \\
\hline $\mathrm{C} 15-\mathrm{C} 16-\mathrm{H} 16 \mathrm{~B}$ & 109.5 \\
\hline $\mathrm{C} 15-\mathrm{C} 16-\mathrm{H} 16 \mathrm{C}$ & 109.5 \\
\hline $\mathrm{H} 16 \mathrm{~A}-\mathrm{C} 16-\mathrm{H} 16 \mathrm{~B}$ & 109.5 \\
\hline $\mathrm{H} 16 \mathrm{~A}-\mathrm{C} 16-\mathrm{H} 16 \mathrm{C}$ & 109.5 \\
\hline $\mathrm{H} 16 \mathrm{~B}-\mathrm{C} 16-\mathrm{H} 16 \mathrm{C}$ & 109.5 \\
\hline $\mathrm{Si} 1-\mathrm{C} 4-\mathrm{H} 4 \mathrm{~A}$ & 109.5 \\
\hline $\mathrm{Si} 1-\mathrm{C} 4-\mathrm{H} 4 \mathrm{~B}$ & 109.5 \\
\hline $\mathrm{Si} 1-\mathrm{C} 4-\mathrm{H} 4 \mathrm{C}$ & 109.5 \\
\hline $\mathrm{H} 4 \mathrm{~A}-\mathrm{C} 4-\mathrm{H} 4 \mathrm{~B}$ & 109.5 \\
\hline $\mathrm{H} 4 \mathrm{~A}-\mathrm{C} 4-\mathrm{H} 4 \mathrm{C}$ & 109.5 \\
\hline $\mathrm{H} 4 \mathrm{~B}-\mathrm{C} 4-\mathrm{H} 4 \mathrm{C}$ & 109.5 \\
\hline $\mathrm{Si} 1-\mathrm{C} 3-\mathrm{H} 3 \mathrm{~A}$ & 109.5 \\
\hline $\mathrm{Si} 1-\mathrm{C} 3-\mathrm{H} 3 \mathrm{~B}$ & 109.5 \\
\hline $\mathrm{Si} 1-\mathrm{C} 3-\mathrm{H} 3 \mathrm{C}$ & 109.5 \\
\hline $\mathrm{H} 3 \mathrm{~A}-\mathrm{C} 3-\mathrm{H} 3 \mathrm{~B}$ & 109.5 \\
\hline $\mathrm{H} 3 \mathrm{~A}-\mathrm{C} 3-\mathrm{H} 3 \mathrm{C}$ & 109.5 \\
\hline $\mathrm{H} 3 \mathrm{~B}-\mathrm{C} 3-\mathrm{H} 3 \mathrm{C}$ & 109.5 \\
\hline $\mathrm{C} 13-\mathrm{C} 14-\mathrm{H} 14 \mathrm{~A}$ & 109.5 \\
\hline C13-C14-H14B & 109.5 \\
\hline $\mathrm{C} 13-\mathrm{C} 14-\mathrm{H} 14 \mathrm{C}$ & 109.5 \\
\hline $\mathrm{H} 14 \mathrm{~A}-\mathrm{C} 14-\mathrm{H} 14 \mathrm{~B}$ & 109.5 \\
\hline $\mathrm{H} 14 \mathrm{~A}-\mathrm{C} 14-\mathrm{H} 14 \mathrm{C}$ & 109.5 \\
\hline $\mathrm{H} 14 \mathrm{~B}-\mathrm{C} 14-\mathrm{H} 14 \mathrm{C}$ & 109.5 \\
\hline $\mathrm{C} 11-\mathrm{C} 12-\mathrm{H} 12 \mathrm{~A}$ & 109.5 \\
\hline $\mathrm{C} 11-\mathrm{C} 12-\mathrm{H} 12 \mathrm{~B}$ & 109.5 \\
\hline $\mathrm{C} 11-\mathrm{C} 12-\mathrm{H} 12 \mathrm{C}$ & 109.5 \\
\hline $\mathrm{H} 12 \mathrm{~A}-\mathrm{C} 12-\mathrm{H} 12 \mathrm{~B}$ & 109.5 \\
\hline $\mathrm{H} 12 \mathrm{~A}-\mathrm{C} 12-\mathrm{H} 12 \mathrm{C}$ & 109.5 \\
\hline $\mathrm{H} 12 \mathrm{~B}-\mathrm{C} 12-\mathrm{H} 12 \mathrm{C}$ & 109.5 \\
\hline $\mathrm{Si} 1-\mathrm{C} 2-\mathrm{H} 2 \mathrm{~A}$ & 109.5 \\
\hline $\mathrm{Si} 1-\mathrm{C} 2-\mathrm{H} 2 \mathrm{~B}$ & 109.5 \\
\hline $\mathrm{Si} 1-\mathrm{C} 2-\mathrm{H} 2 \mathrm{C}$ & 109.5 \\
\hline $\mathrm{H} 2 \mathrm{~A}-\mathrm{C} 2-\mathrm{H} 2 \mathrm{~B}$ & 109.5 \\
\hline $\mathrm{H} 2 \mathrm{~A}-\mathrm{C} 2-\mathrm{H} 2 \mathrm{C}$ & 109.5 \\
\hline $\mathrm{H} 2 \mathrm{~B}-\mathrm{C} 2-\mathrm{H} 2 \mathrm{C}$ & 109.5 \\
\hline
\end{tabular}




$\begin{array}{ll}\text { V1-P2-C7-C8 } & -52.61(13) \\ \text { V1-P2-C9-C10 } & 175.65(11) \\ \text { V1-P2-C5-C6 } & 63.43(14) \\ \text { V1-P1-C15-C16 } & -67.56(14) \\ \text { V1-P1-C13-C14 } & 56.16(14) \\ \text { V1-P1-C11-C12 } & -173.03(13) \\ \text { P2-V1-C1-Si1 } & -99.25(13) \\ \text { P1-V1-C1-Si1 } & 91.25(13) \\ \text { C11-V1-C1-Si1 } & 174.99(10) \\ \text { O1-V1-C1-Si1 } & -2.83(15) \\ \text { C15-P1-C13-C14 } & -176.01(14) \\ \text { C15-P1-C11-C12 } & 56.38(16) \\ \text { C7-P2-C9-C10 } & 52.14(14)\end{array}$

$\begin{array}{ll}\mathrm{C} 7-\mathrm{P} 2-\mathrm{C} 5-\mathrm{C} 6 & -171.68(13) \\ \mathrm{C} 9-\mathrm{P} 2-\mathrm{C} 7-\mathrm{C} 8 & 69.26(14) \\ \mathrm{C} 9-\mathrm{P} 2-\mathrm{C} 5-\mathrm{C} 6 & -62.55(15) \\ \mathrm{C} 13-\mathrm{P} 1-\mathrm{C} 15-\mathrm{C} 16 & 168.11(13) \\ \mathrm{C} 13-\mathrm{P} 1-\mathrm{C} 11-\mathrm{C} 12 & -49.88(16) \\ \mathrm{C} 5-\mathrm{P} 2-\mathrm{C} 7-\mathrm{C} 8 & 179.06(13) \\ \mathrm{C} 5-\mathrm{P} 2-\mathrm{C} 9-\mathrm{C} 10 & -53.82(14) \\ \mathrm{C} 11-\mathrm{P} 1-\mathrm{C} 15-\mathrm{C} 16 & 59.25(15) \\ \mathrm{C} 11-\mathrm{P} 1-\mathrm{C} 13-\mathrm{C} 14 & -66.24(15) \\ \mathrm{C} 4-\mathrm{S} 1-\mathrm{C} 1-\mathrm{V} 1 & -125.02(14) \\ \mathrm{C} 3-\mathrm{Si} 1-\mathrm{C} 1-\mathrm{V} 1 & -4.47(17) \\ \mathrm{C} 2-\mathrm{Si} 1-\mathrm{C} 1-\mathrm{V} 1 & 116.67(15)\end{array}$




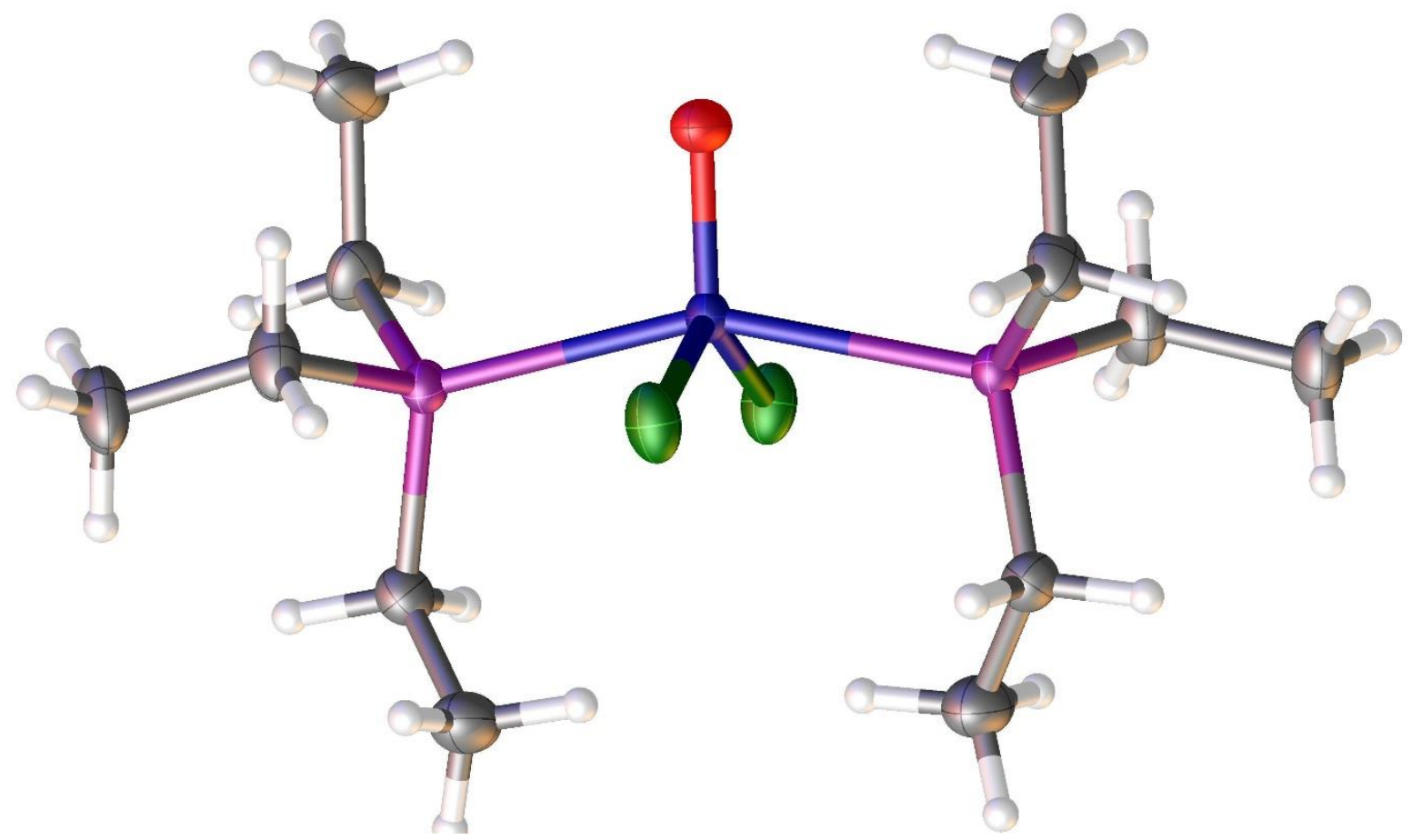

Figure S5. Molecular structure of $\mathrm{Cl}_{2} \mathrm{VO}\left(\mathrm{PEt}_{3}\right)_{2}(\mathrm{CCDC} 2093139)$. Atomic displacement ellipsoids are drawn at the $50 \%$ probability level.

$$
\begin{aligned}
& \text { Crystal data } \\
& \mathrm{C}_{12} \mathrm{H}_{30} \mathrm{Cl}_{2} \mathrm{OP}_{2} \mathrm{~V} \\
& M_{r}=374.14 \\
& \text { Orthorhombic, } \mathrm{Pbcn} \\
& a=8.6708(7) \AA \\
& b=18.0768(14) \AA \\
& c=12.2928(9) \AA \\
& V=1926.8(3) \AA^{3} \\
& Z=4 \\
& F(000)=788
\end{aligned}
$$

Data collection

Bruker APEX-II CCD

diffractometer

$\omega$ scans

4837 measured reflections

2237 independent reflections

2047 reflections with $I>2 \sigma(I)$

Refinement

Refinement on $F^{2}$

Least-squares matrix: full

$R\left[F^{2}>2 \sigma\left(F^{2}\right)\right]=0.035$

$w R\left(F^{2}\right)=0.093$

$S=1.06$

2237 reflections

86 parameters

0 restraints

Primary atom site location: dual
$D_{\mathrm{x}}=1.290 \mathrm{Mg} \mathrm{m}^{-3}$

Mo $K \alpha$ radiation, $\lambda=0.71073 \AA$

Cell parameters from 3197 reflections

$\theta=3.1-28.3^{\circ}$

$\mu=0.95 \mathrm{~mm}-1$

$T=150 \mathrm{~K}$

Block, green

$0.3 \times 0.25 \times 0.17 \mathrm{~mm}$

$R_{\text {int }}=0.033$

$\theta_{\max }=28.3^{\circ}, \theta_{\min }=3.1^{\circ}$

$h=-11 \rightarrow 4$

$k=-22 \rightarrow 19$

$l=-16 \rightarrow 10$

Secondary atom site location: difference Fourier map Hydrogen site location: inferred from neighboring sites $\mathrm{H}$-atom parameters constrained

$w=1 /\left[\sigma_{2}\left(F_{\mathrm{o}}{ }^{2}\right)+(0.0412 P)^{2}+1.6139 P\right]$

where $P=\left(F_{\mathrm{o}}^{2}+2 F_{\mathrm{c}}^{2}\right) / 3$

$(\Delta / \sigma)_{\max }=0.001$

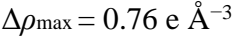

$\Delta \rho \min =-0.30$ e $\AA^{-3}$ 
Special details

Geometry. All e.s.d.'s (except the e.s.d. in the dihedral angle between two l.s. planes) are estimated using the full covariance matrix. The cell e.s.d.'s are taken into account individually in the estimation of e.s.d.'s in distances, angles and torsion angles; correlations between e.s.d.'s in cell parameters are only used when they are defined by crystal symmetry. An approximate (isotropic) treatment of cell e.s.d.'s is used for estimating e.s.d.'s involving 1.s. planes.

References

Dolomanov, O. V., Bourhis, L. J., Gildea, R. J., Howard, J. A. K. \& Puschmann, H. (2009). J. Appl. Cryst. 42, $339-341$.

Sheldrick, G. M. (2015). Acta Cryst. C71, 3-8.

Fractional atomic coordinates and isotropic or equivalent isotropic displacement parameters $\left(\AA^{2}\right)$

\begin{tabular}{lllll} 
& \multicolumn{1}{c}{$x$} & \multicolumn{1}{c}{$y$} & \multicolumn{1}{c}{$z$} & $U$ iso*/Ueq \\
V1 & 0.500000 & $0.39990(3)$ & 0.750000 & $0.02431(13)$ \\
P02 & $0.67990(5)$ & $0.37130(3)$ & $0.59576(4)$ & $0.02635(14)$ \\
C11 & $0.30283(6)$ & $0.35553(4)$ & $0.64321(4)$ & $0.03977(16)$ \\
O1 & 0.500000 & $0.48731(13)$ & 0.750000 & $0.0412(5)$ \\
C1 & $0.6037(3)$ & $0.38809(16)$ & $0.46057(18)$ & $0.0449(6)$ \\
H1A & 0.505447 & 0.360582 & 0.453586 & $0.054^{*}$ \\
H1B & 0.578975 & $0.27500(13)$ & 0.454666 & $0.054^{*}$ \\
C5 & $0.7495(3)$ & 0.266821 & $0.59797(18)$ & $0.0375(5)$ \\
H5A & 0.814579 & 0.268428 & 0.532899 & $0.045^{*}$ \\
H5B & 0.815953 & $0.42107(15)$ & 0.662740 & $0.045^{*}$ \\
C3 & $0.8612(3)$ & 0.408105 & $0.6055(2)$ & $0.0426(5)$ \\
H3A & 0.912289 & 0.405245 & 0.674900 & $0.051^{*}$ \\
H3B & 0.929642 & $0.36732(18)$ & 0.545371 & $0.051^{*}$ \\
C2 & $0.7057(3)$ & 0.377758 & $0.3645(2)$ & $0.0545(7)$ \\
H2A & 0.651051 & 0.314503 & 0.296464 & $0.082^{*}$ \\
H2B & 0.730708 & 0.396329 & 0.368150 & $0.082^{*}$ \\
H2C & 0.801148 & $0.21715(15)$ & 0.367129 & $0.082^{*}$ \\
C6 & $0.6270(3)$ & 0.221740 & $0.6002(2)$ & $0.0525(6)$ \\
H6A & 0.562357 & 0.223633 & 0.535108 & $0.079^{*}$ \\
H6B & 0.563156 & 0.168064 & 0.665261 & $0.079^{*}$ \\
H6C & 0.674904 & $0.50497(17)$ & 0.601560 & $0.079^{*}$ \\
C4 & $0.8396(4)$ & 0.518939 & $0.6000(3)$ & $0.0733(11)$ \\
H4A & 0.804524 & 0.529474 & 0.527079 & $0.110^{*}$ \\
H4B & 0.937987 & 0.520265 & 0.615656 & $0.110^{*}$ \\
H4C & 0.762588 & 0.653844 & $0.110^{*}$
\end{tabular}

Atomic displacement parameters $\left(\AA^{2}\right)$

\begin{tabular}{llllllr} 
& \multicolumn{1}{c}{$U^{11}$} & $U^{22}$ & $U^{33}$ & \multicolumn{1}{c}{$U^{12}$} & $U^{13}$ & $U^{23}$ \\
V1 & $0.0259(2)$ & $0.0254(3)$ & $0.0217(2)$ & 0.000 & $0.00389(16)$ & 0.000 \\
P02 & $0.0263(2)$ & $0.0276(3)$ & $0.0251(2)$ & $0.00125(18)$ & $0.00518(18)$ & $0.00084(18)$ \\
C11 & $0.0295(2)$ & $0.0620(4)$ & $0.0277(2)$ & $-0.0014(2)$ & $-0.00206(18)$ & $-0.0052(2)$ \\
O1 & $0.0493(13)$ & $0.0275(13)$ & $0.0469(12)$ & 0.000 & $0.0152(10)$ & 0.000 \\
C1 & $0.0428(12)$ & $0.0637(17)$ & $0.0282(10)$ & $0.0130(11)$ & $0.0051(9)$ & $0.0057(10)$ \\
C5 & $0.0404(11)$ & $0.0344(13)$ & $0.0378(10)$ & $0.0036(9)$ & $0.0072(9)$ & $-0.0016(9)$ \\
C3 & $0.0367(10)$ & $0.0483(15)$ & $0.0429(12)$ & $-0.0138(10)$ & $0.0117(10)$ & $-0.0014(10)$ \\
C2 & $0.0616(16)$ & $0.073(2)$ & $0.0292(11)$ & $0.0149(14)$ & $0.0115(11)$ & $0.0036(11)$ \\
C6 & $0.0591(15)$ & $0.0366(15)$ & $0.0618(16)$ & $-0.0037(11)$ & $0.0146(13)$ & $-0.0032(12)$ \\
C4 & $0.082(2)$ & $0.0408(18)$ & $0.097(2)$ & $-0.0244(15)$ & $0.052(2)$ & $-0.0149(16)$
\end{tabular}


Geometric parameters $\left(\AA,^{o}\right)$

$\mathrm{V} 1-\mathrm{P} 02$

$\mathrm{V} 1-\mathrm{P} 02^{\mathrm{i}}$

2.5091 (5)

2.5092 (5)

2.2998 (5)

2.2998 (5)

1.580 (2)

1.814 (2)

1.843 (2)

1.815 (2)

0.9900

0.9900

1.523 (3)

0.9900

0.9900

156.22 (3)

87.648 (19)

84.109 (19)

87.648 (19)

84.108 (19)

139.18 (4)

101.890 (17)

101.890 (17)

110.41 (2)

110.41 (2)

115.55 (8)

106.91 (11)

107.03 (12)

112.77 (7)

112.74 (8)

100.59 (12)

108.0

108.0

107.2

117.22 (17)

108.0

108.0

108.4

108.4

107.5

115.44 (17)

$-176.6(2)$

54.93 (19)

$-62.4(2)$

-73.1 (2)

65.8 (2)
C5- 6 6

C3-H3A

C3-H3B

C3- 44

$\mathrm{C} 2-\mathrm{H} 2 \mathrm{~A}$

C2- $\mathrm{H} 2 \mathrm{~B}$

$\mathrm{C} 2-\mathrm{H} 2 \mathrm{C}$

C6-H6A

C6-H6B

C6- $\mathrm{H} 6 \mathrm{C}$

C4-H4A

C4-H4B

$\mathrm{C} 4-\mathrm{H} 4 \mathrm{C}$

C6- C5-H5A

C6- C5-H5B

$\mathrm{P} 02-\mathrm{C} 3-\mathrm{H} 3 \mathrm{~A}$

$\mathrm{P} 02-\mathrm{C} 3-\mathrm{H} 3 \mathrm{~B}$

$\mathrm{H} 3 \mathrm{~A}-\mathrm{C} 3-\mathrm{H} 3 \mathrm{~B}$

$\mathrm{C} 4-\mathrm{C} 3-\mathrm{P} 02$

$\mathrm{C} 4-\mathrm{C} 3-\mathrm{H} 3 \mathrm{~A}$

$\mathrm{C} 4-\mathrm{C} 3-\mathrm{H} 3 \mathrm{~B}$

$\mathrm{C} 1-\mathrm{C} 2-\mathrm{H} 2 \mathrm{~A}$

$\mathrm{C} 1-\mathrm{C} 2-\mathrm{H} 2 \mathrm{~B}$

$\mathrm{C} 1-\mathrm{C} 2-\mathrm{H} 2 \mathrm{C}$

$\mathrm{H} 2 \mathrm{~A}-\mathrm{C} 2-\mathrm{H} 2 \mathrm{~B}$

$\mathrm{H} 2 \mathrm{~A}-\mathrm{C} 2-\mathrm{H} 2 \mathrm{C}$

$\mathrm{H} 2 \mathrm{~B}-\mathrm{C} 2-\mathrm{H} 2 \mathrm{C}$

$\mathrm{C} 5-\mathrm{C} 6-\mathrm{H} 6 \mathrm{~A}$

C5- C6- H6B

$\mathrm{C} 5-\mathrm{C} 6-\mathrm{H} 6 \mathrm{C}$

H6A-C6-H6B

$\mathrm{H} 6 \mathrm{~A}-\mathrm{C} 6-\mathrm{H} 6 \mathrm{C}$

$\mathrm{H} 6 \mathrm{~B}-\mathrm{C} 6-\mathrm{H} 6 \mathrm{C}$

$\mathrm{C} 3-\mathrm{C} 4-\mathrm{H} 4 \mathrm{~A}$

$\mathrm{C} 3-\mathrm{C} 4-\mathrm{H} 4 \mathrm{~B}$

$\mathrm{C} 3-\mathrm{C} 4-\mathrm{H} 4 \mathrm{C}$

$\mathrm{H} 4 \mathrm{~A}-\mathrm{C} 4-\mathrm{H} 4 \mathrm{~B}$

$\mathrm{H} 4 \mathrm{~A}-\mathrm{C} 4-\mathrm{H} 4 \mathrm{C}$

$\mathrm{H} 4 \mathrm{~B}-\mathrm{C} 4-\mathrm{H} 4 \mathrm{C}$

$\mathrm{C} 5-\mathrm{P} 02-\mathrm{C} 1-\mathrm{C} 2$

$\mathrm{C} 5-\mathrm{P} 02-\mathrm{C} 3-\mathrm{C} 4$

$\mathrm{C} 3-\mathrm{P} 02-\mathrm{C} 1-\mathrm{C} 2$

C3-P02-C5-C6
$1.491(4)$
0.9900
0.9900
$1.530(4)$
0.9800
0.9800
0.9800
0.9800
0.9800
0.9800
0.9800
0.9800
0.9800
108.4
108.4
109.1
109.1
107.8
$112.5(2)$
109.1

109.1

109.5

109.5

109.5

109.5

109.5

109.5

109.5

109.5

109.5

109.5

109.5

109.5

109.5

109.5

109.5

109.5

109.5

109.5

-50.2 (3)

177.3 (2)

56.9 (3)

175.26

(19) $\mathrm{C} 1-\mathrm{P} 02-\mathrm{C} 3-\mathrm{C} 4$

Symmetry code: (i) $-x+1, y,-z+3 / 2$. 


\section{NMR spectra}

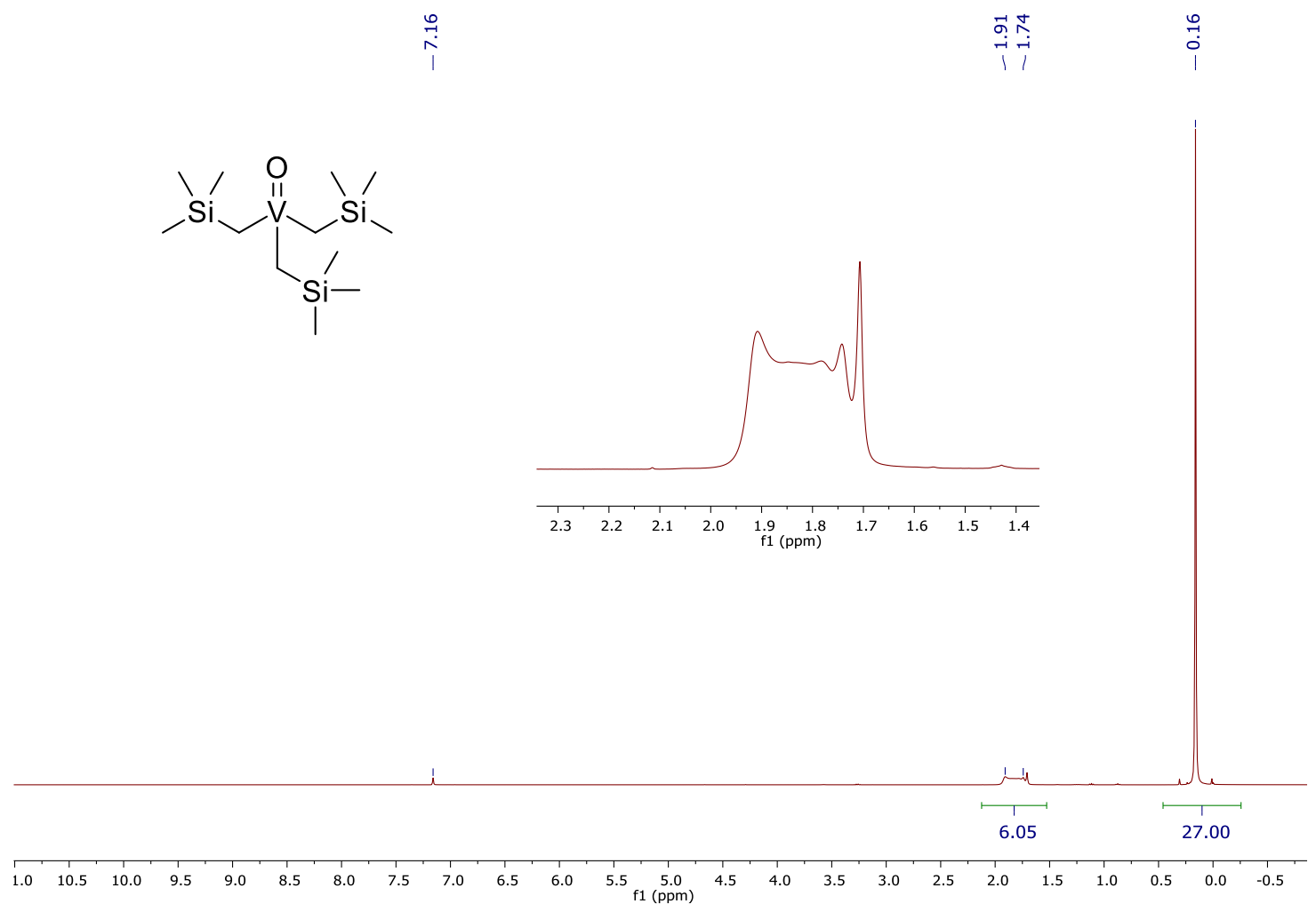

Figure S6. ${ }^{1} \mathrm{H}$ NMR spectrum $12\left(\mathrm{C}_{6} \mathrm{D}_{6}, 400 \mathrm{MHz}, 24^{\circ} \mathrm{C}\right)$.

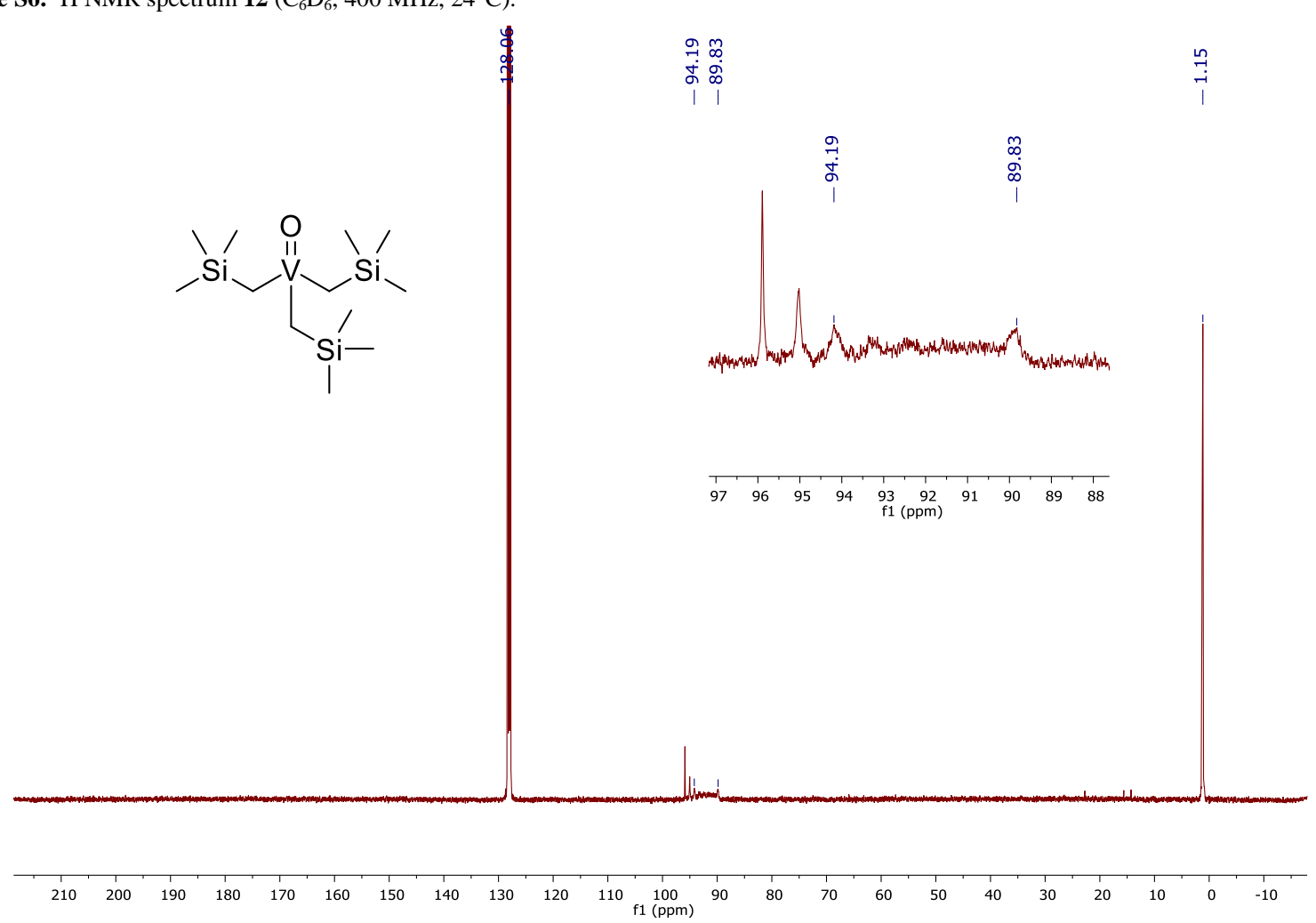

Figure S7. ${ }^{13} \mathrm{C}$ NMR spectrum of $12\left(\mathrm{C}_{6} \mathrm{D}_{6}, 101 \mathrm{MHz}, 24{ }^{\circ} \mathrm{C}\right)$. 


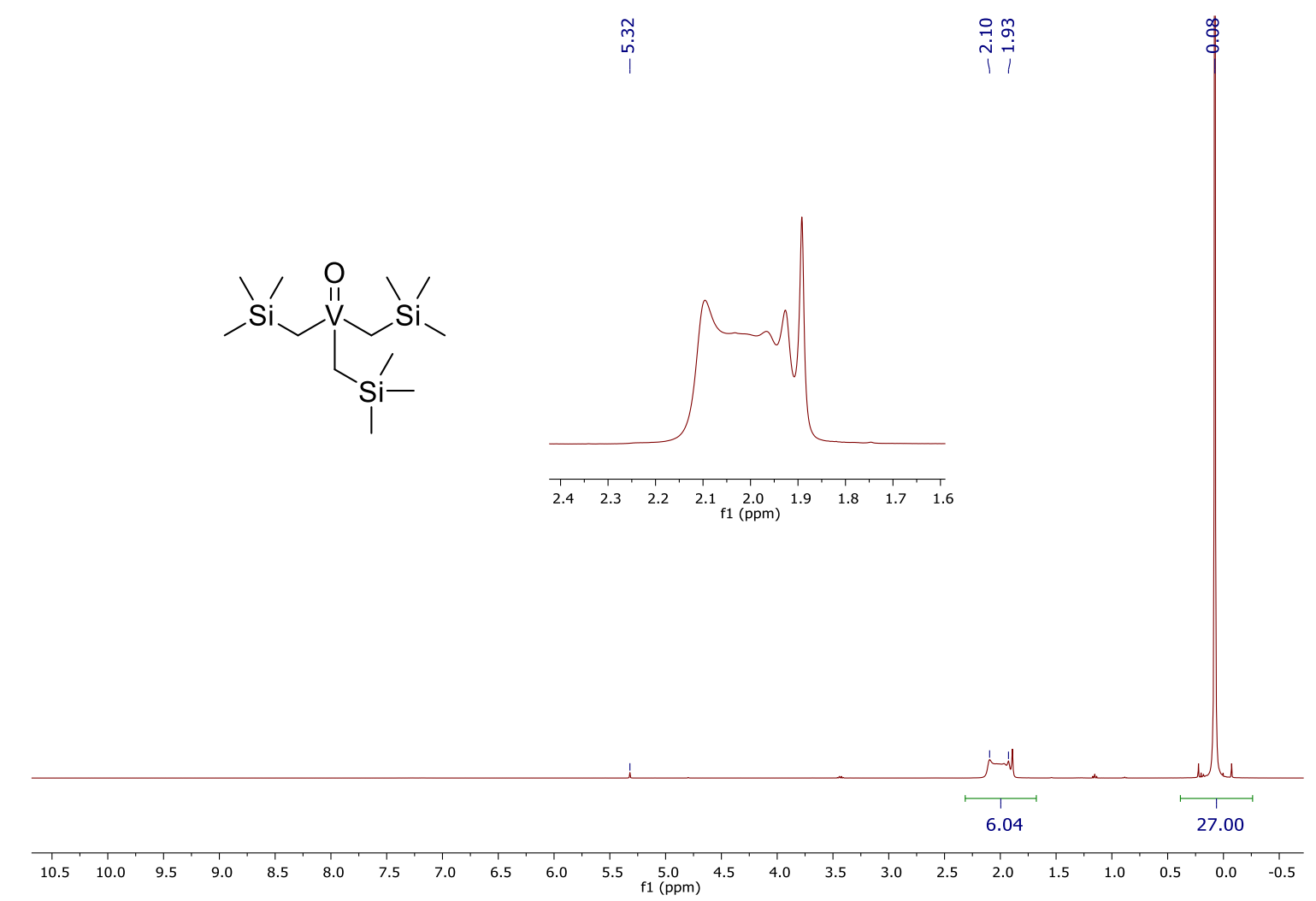

Figure S8. ${ }^{1} \mathrm{H}$ NMR spectrum $12\left(\mathrm{CD}_{2} \mathrm{Cl}_{2}, 400 \mathrm{MHz}, 24^{\circ} \mathrm{C}\right)$.
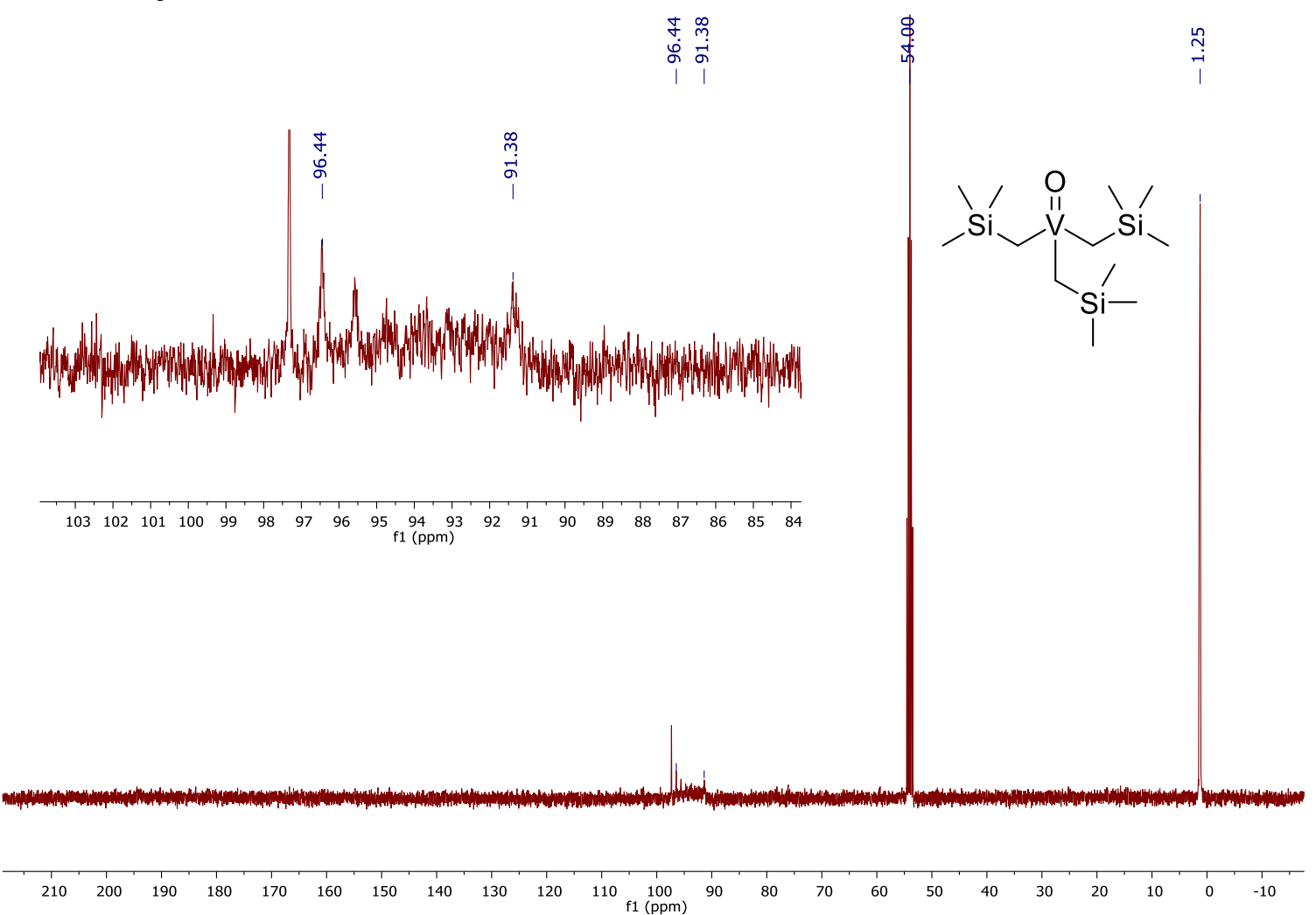

Figure S9. ${ }^{13} \mathrm{C}$ NMR spectrum of $\mathbf{1 2}\left(\mathrm{CD}_{2} \mathrm{Cl}_{2}, 101 \mathrm{MHz}, 24^{\circ} \mathrm{C}\right)$. 

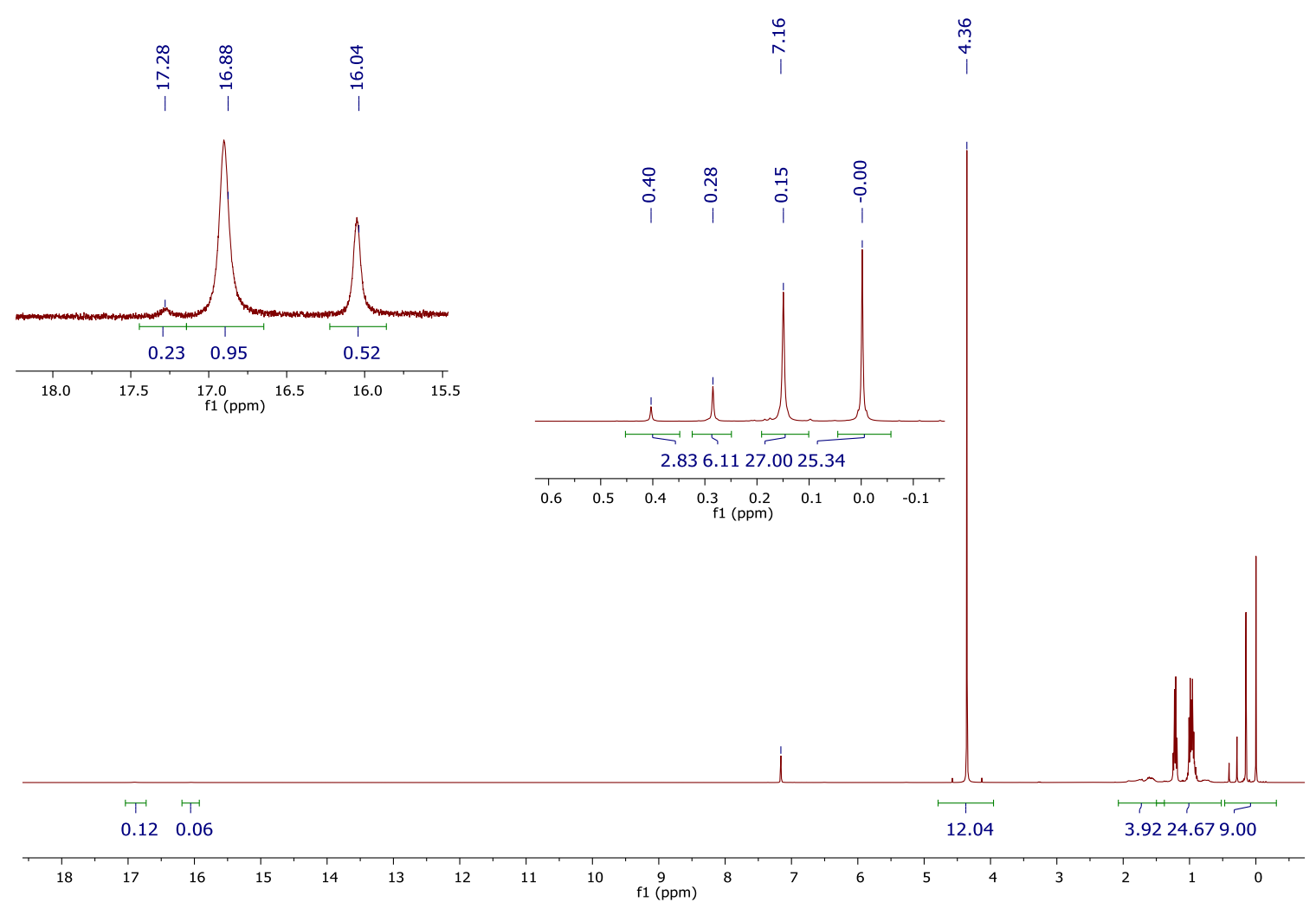

Figure S10. Characteristic signals in ${ }^{1} \mathrm{H}$ NMR spectrum used to monitor the progress conversion of $\mathbf{1 2}$ to $\mathbf{1 3}+\mathbf{1 4}\left(\mathrm{C}_{6} \mathrm{D}_{6}, 400 \mathrm{MHz}, 24^{\circ} \mathrm{C}\right)$.

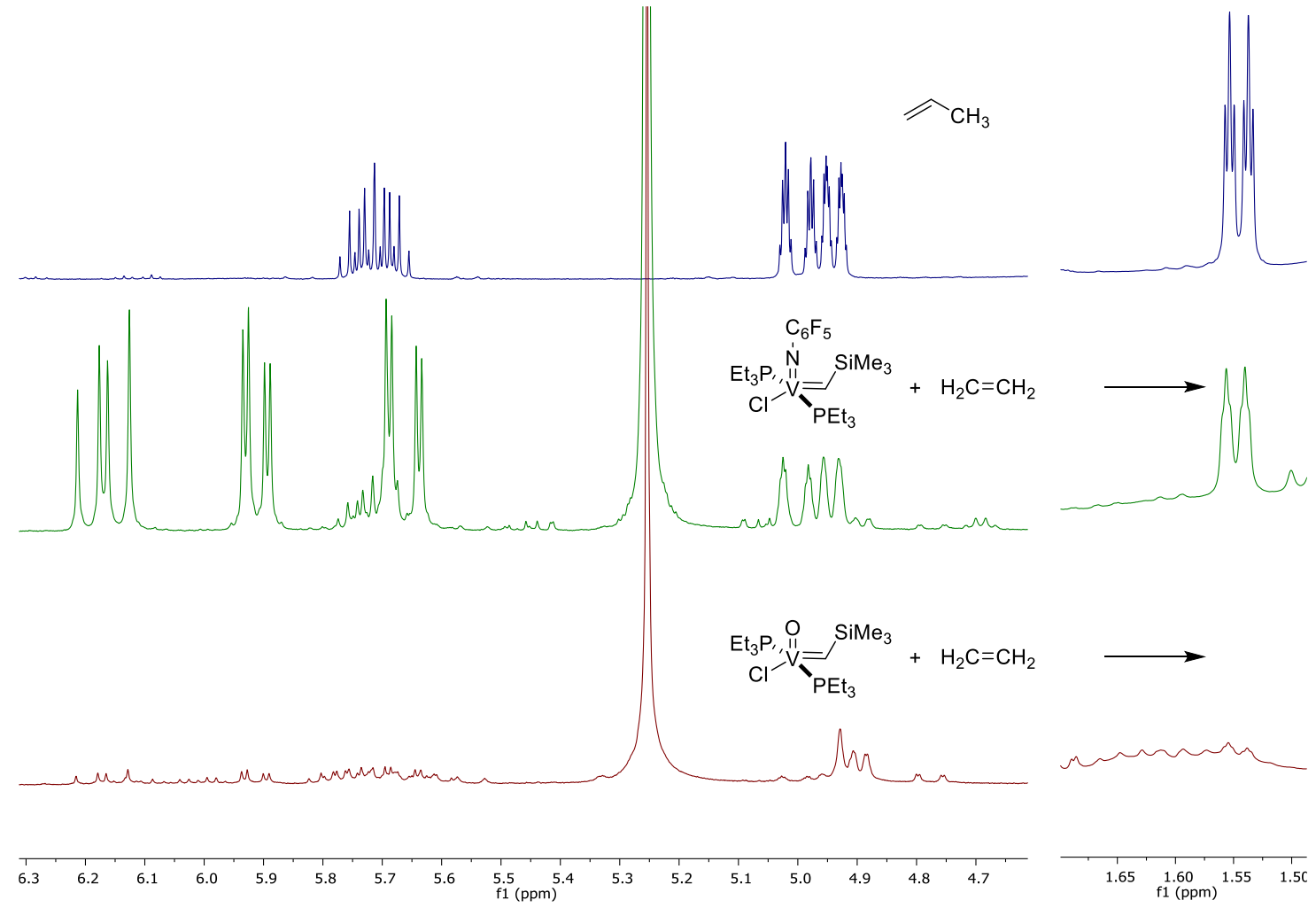

Figure S11. Fragment of ${ }^{1} \mathrm{H}$ NMR spectrum: Bottom: reaction of $\mathbf{1 4}$ with excess of ethylene. Middle: reaction of $\mathbf{5 b}$ with excess of ethylene Top: propylene $\left(\mathrm{C}_{6} \mathrm{D}_{6}, 400 \mathrm{MHz}, 24^{\circ} \mathrm{C}\right)$. 

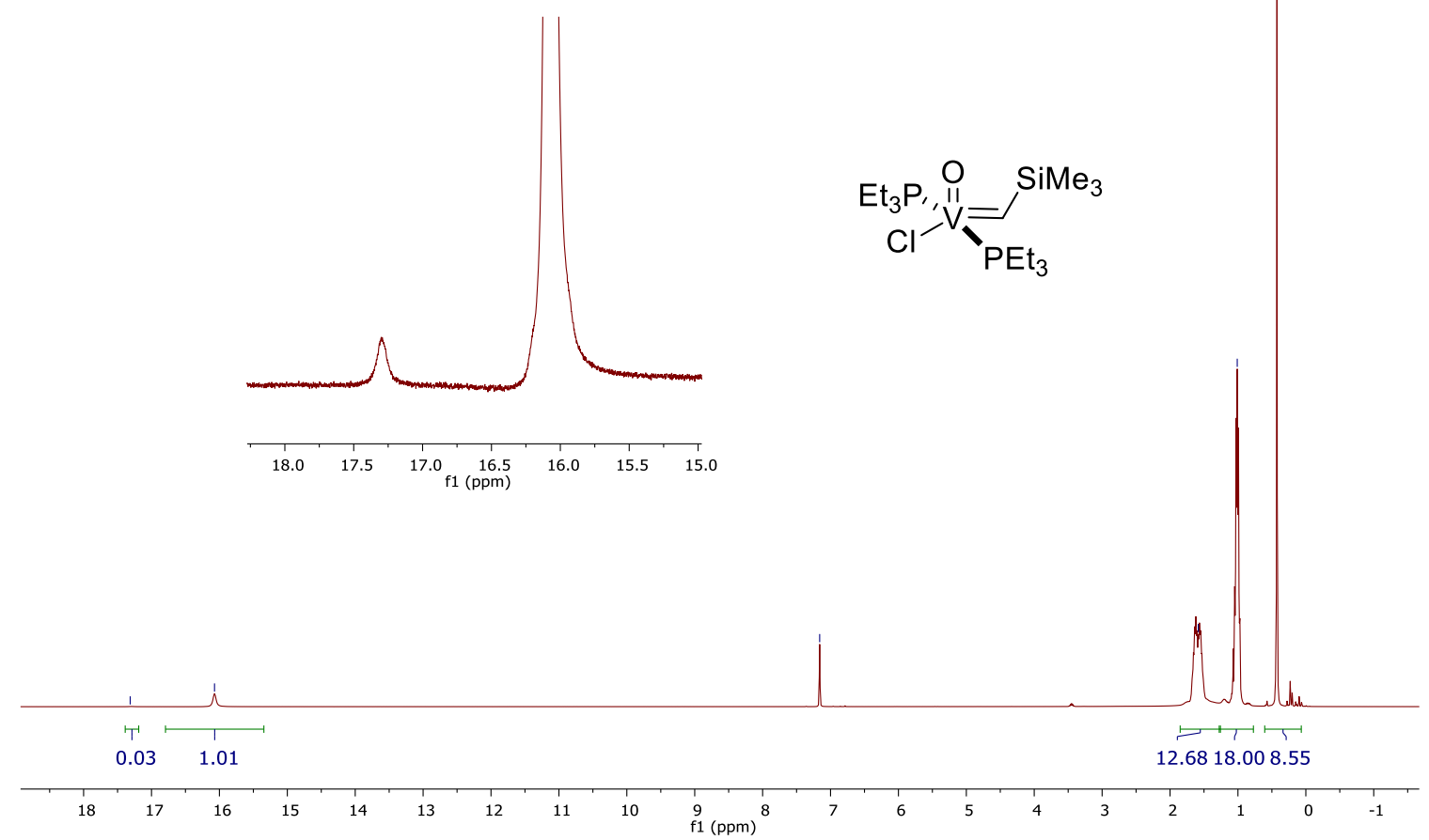

Figure S12. ${ }^{1} \mathrm{H}$ NMR spectrum $14\left(\mathrm{C}_{6} \mathrm{D}_{6}, 400 \mathrm{MHz}, 24^{\circ} \mathrm{C}\right)$.

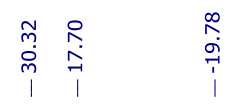
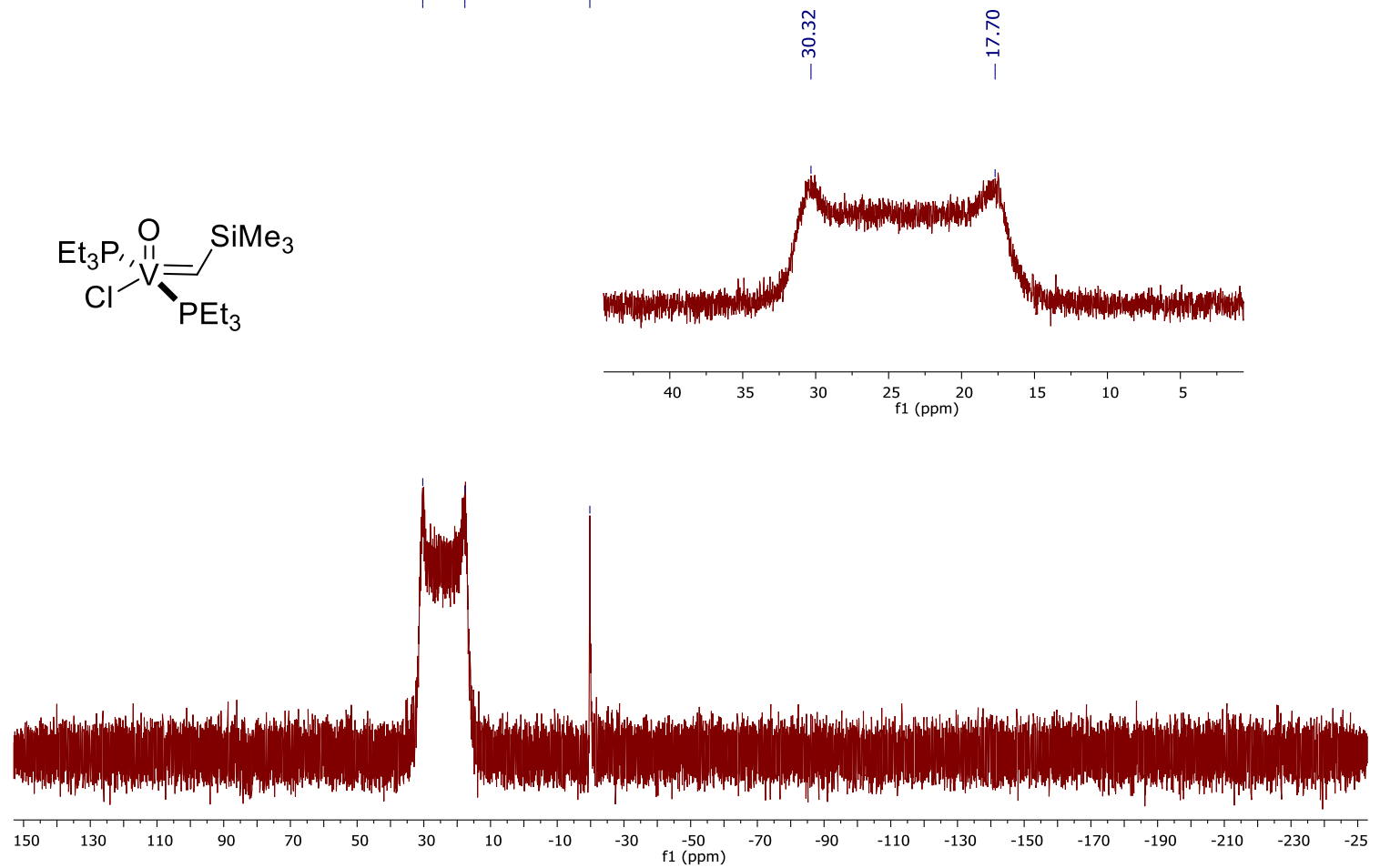

Figure S13. ${ }^{31} \mathrm{P}$ NMR spectrum of $\mathbf{1 4}\left(\mathrm{C}_{6} \mathrm{D}_{6}, 162 \mathrm{MHz}, 24^{\circ} \mathrm{C}\right)$. 


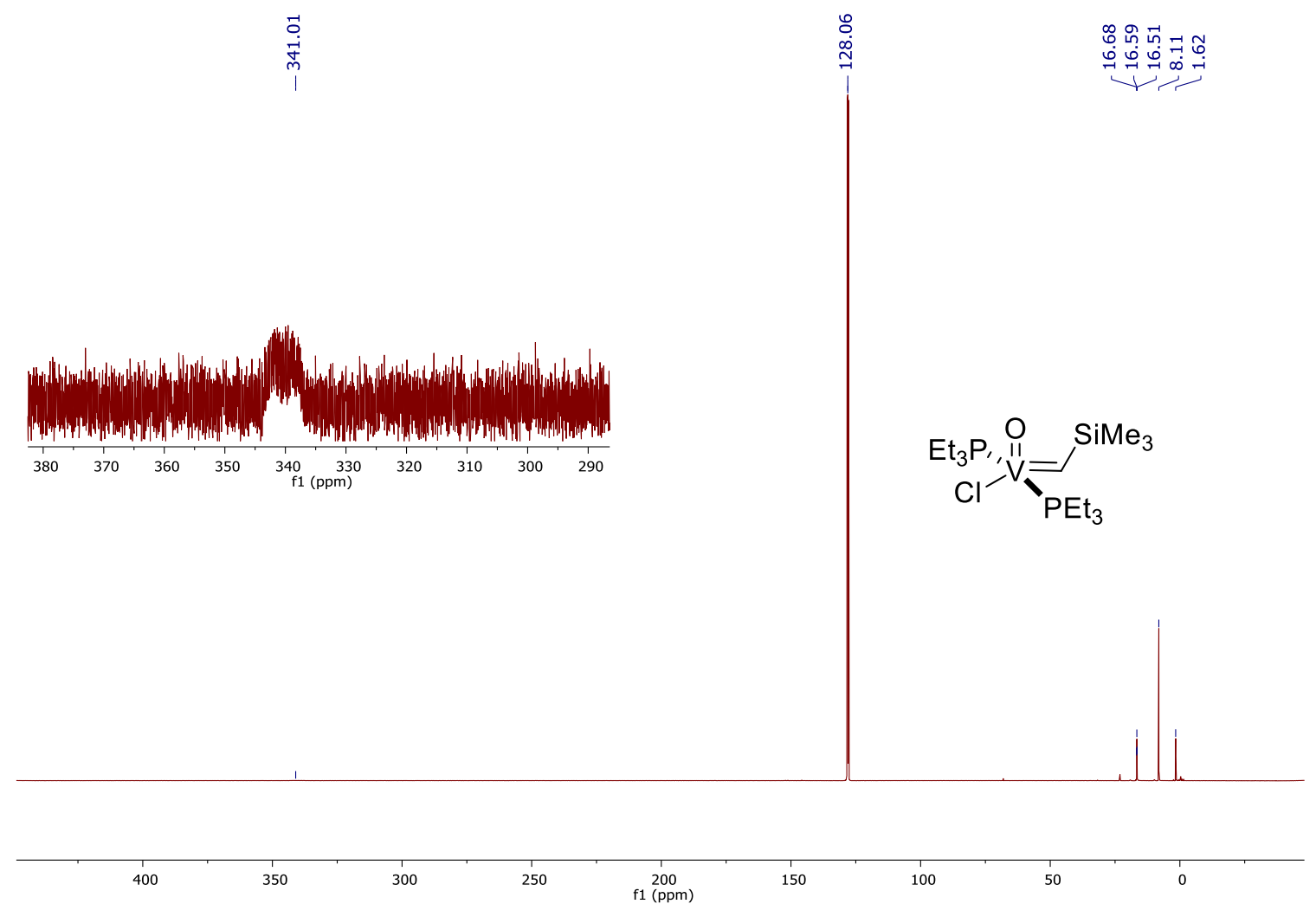

Figure S14. ${ }^{13} \mathrm{C}$ NMR spectrum of $\mathbf{1 4}\left(\mathrm{C}_{6} \mathrm{D}_{6}, 101 \mathrm{MHz}, 24^{\circ} \mathrm{C}\right)$. 


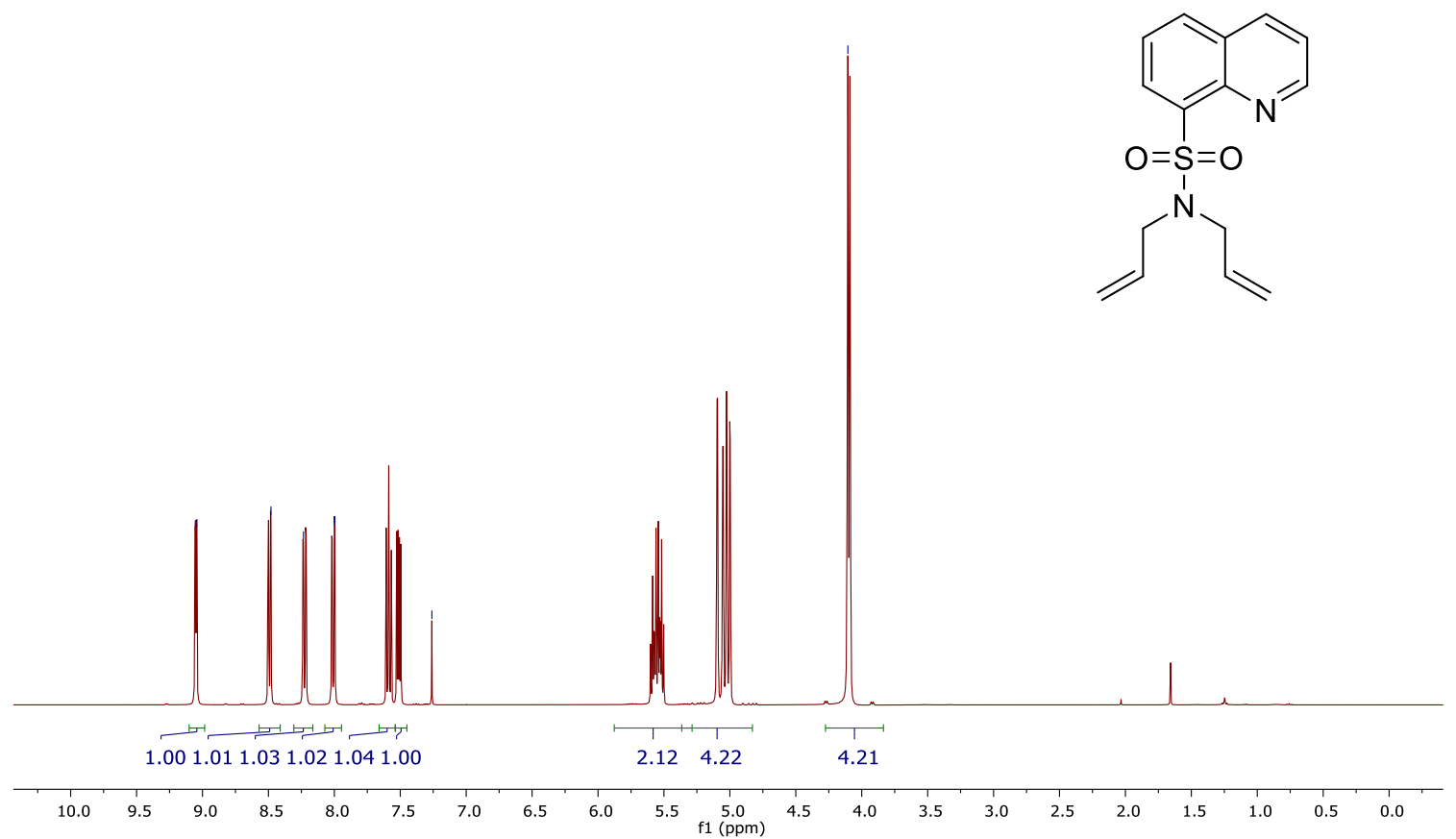

Figure S15. ${ }^{1} \mathrm{H}$ NMR spectrum $\mathbf{S 9}\left(\mathrm{C}_{6} \mathrm{D}_{6}, 400 \mathrm{MHz}, 24^{\circ} \mathrm{C}\right)$.

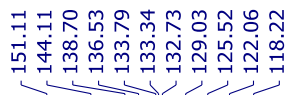

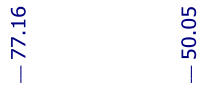
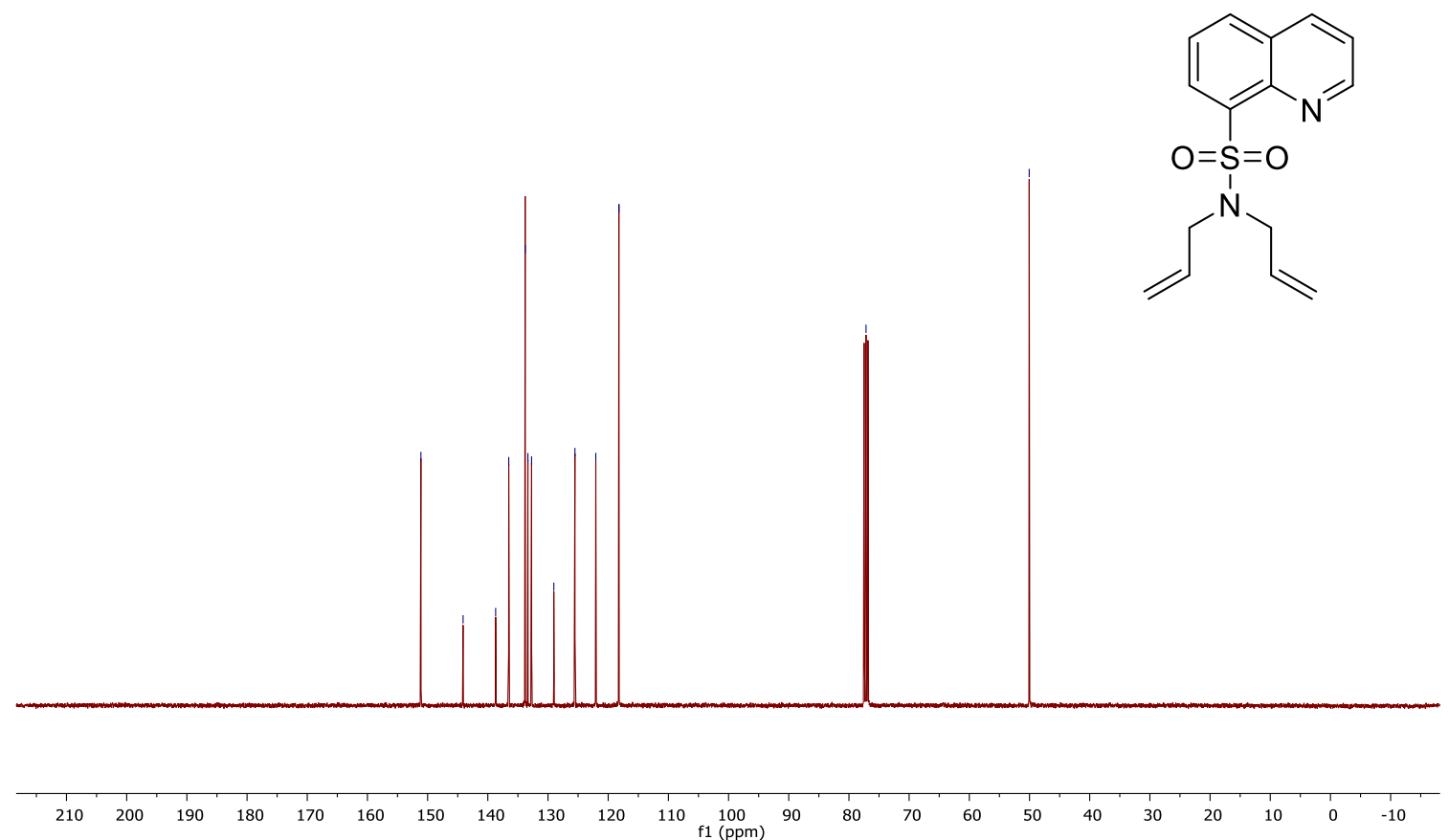

Figure S16. ${ }^{13} \mathrm{C}$ NMR spectrum of $\mathbf{S 9}\left(\mathrm{C}_{6} \mathrm{D}_{6}, 101 \mathrm{MHz}, 24^{\circ} \mathrm{C}\right)$. 


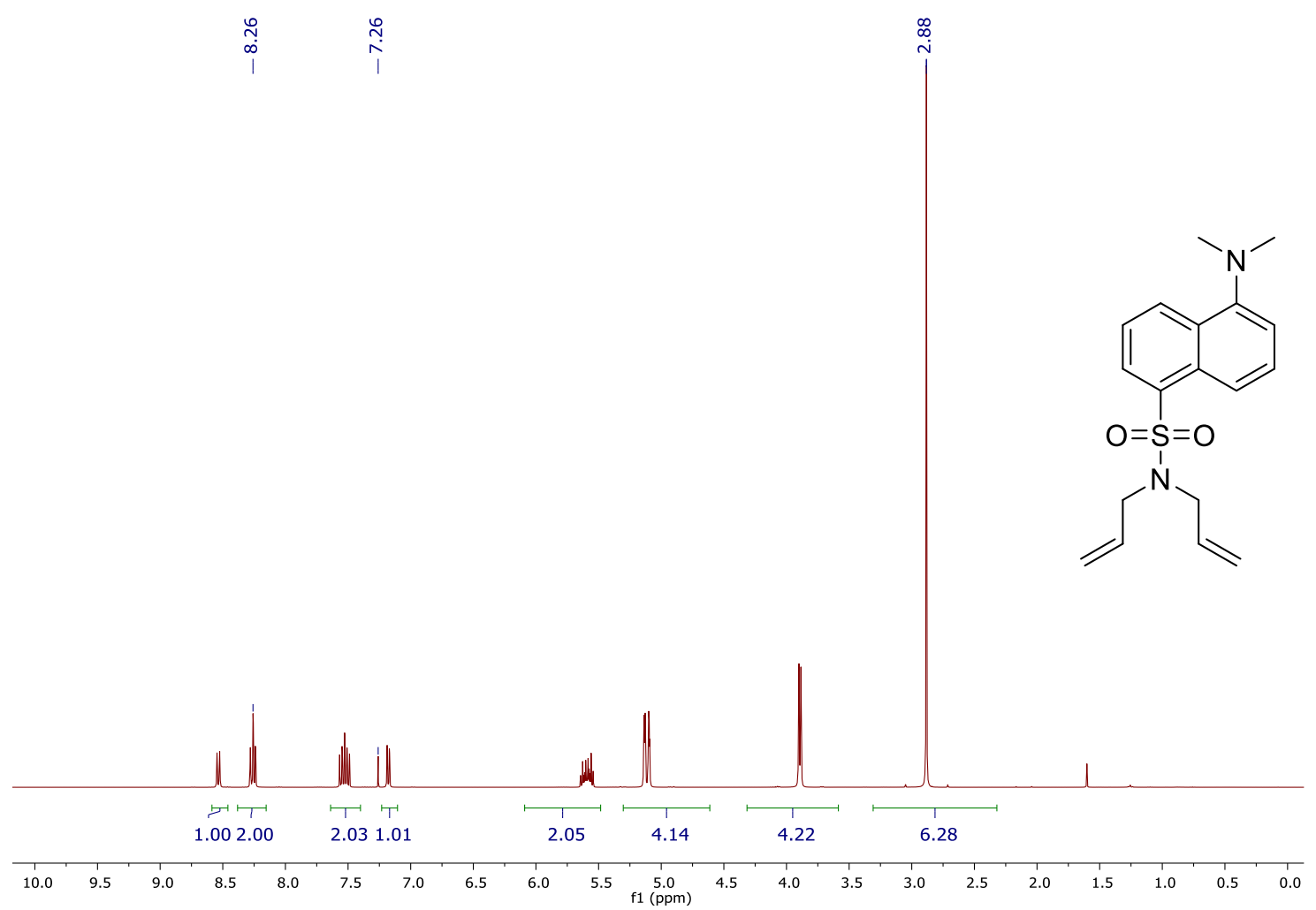

Figure S17. ${ }^{1} \mathrm{H}$ NMR spectrum $\mathbf{S 1 0}\left(\mathrm{C}_{6} \mathrm{D}_{6}, 400 \mathrm{MHz}, 24^{\circ} \mathrm{C}\right)$.
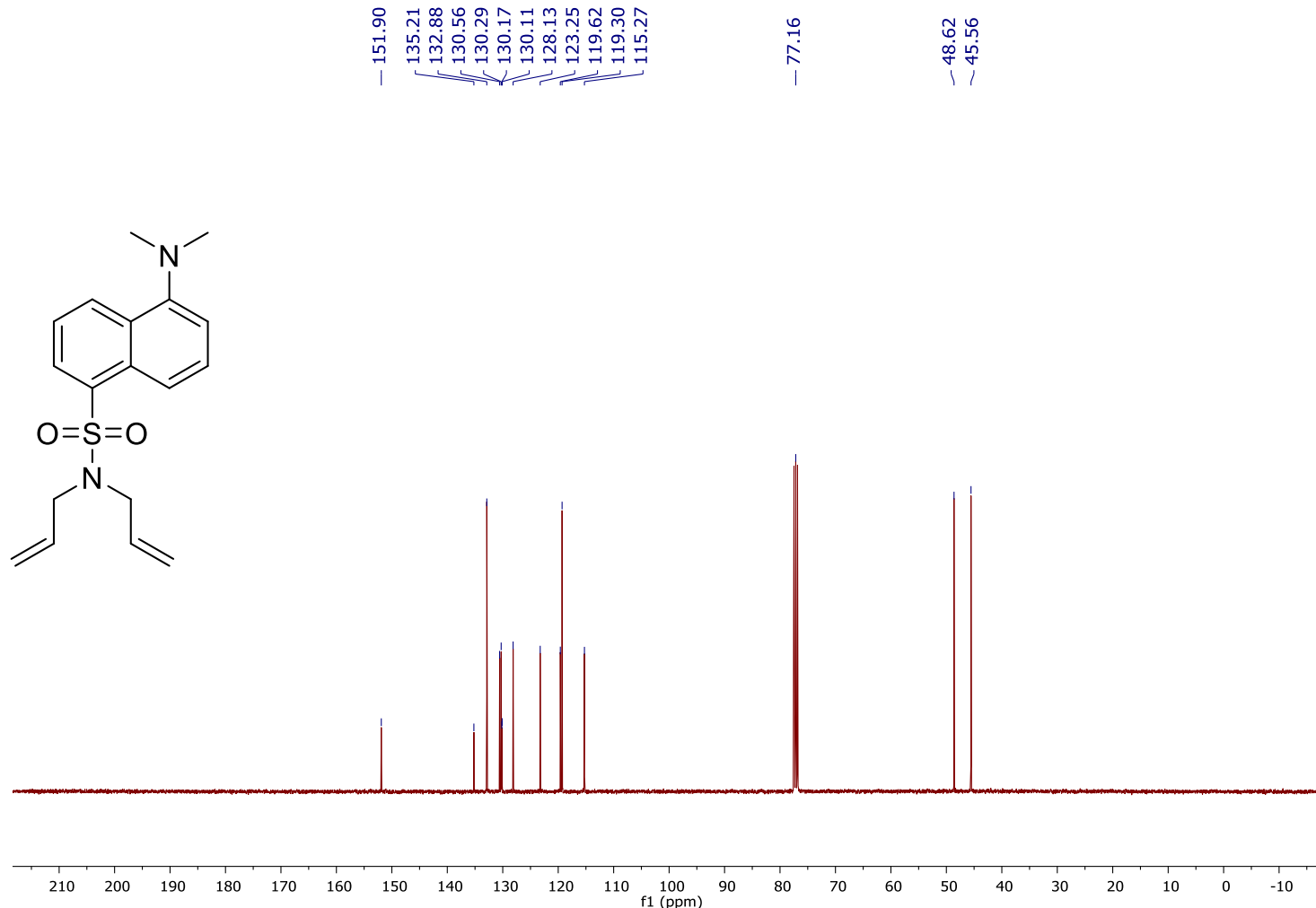

Figure S18. ${ }^{13} \mathrm{C}$ NMR spectrum of $\mathbf{S 1 0}\left(\mathrm{C}_{6} \mathrm{D}_{6}, 101 \mathrm{MHz}, 24^{\circ} \mathrm{C}\right)$. 


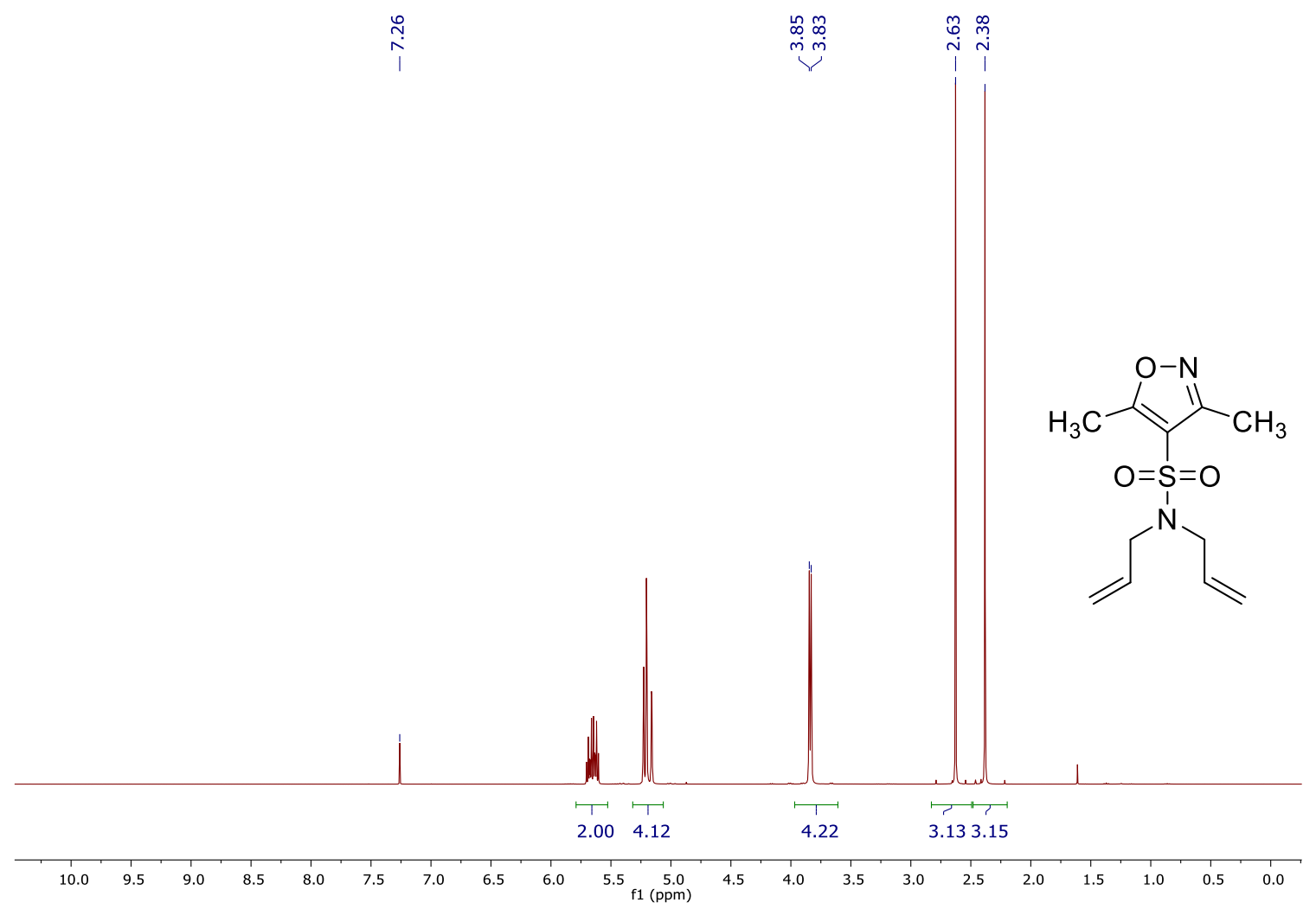

Figure S19. ${ }^{1} \mathrm{H}$ NMR spectrum $\mathbf{S 1 1}\left(\mathrm{C}_{6} \mathrm{D}_{6}, 400 \mathrm{MHz}, 24^{\circ} \mathrm{C}\right)$.

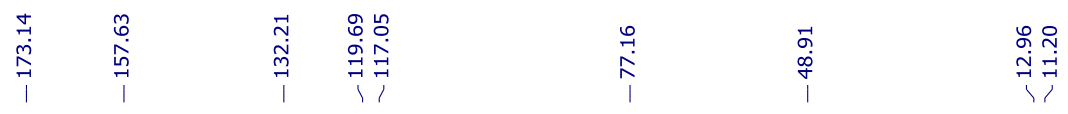
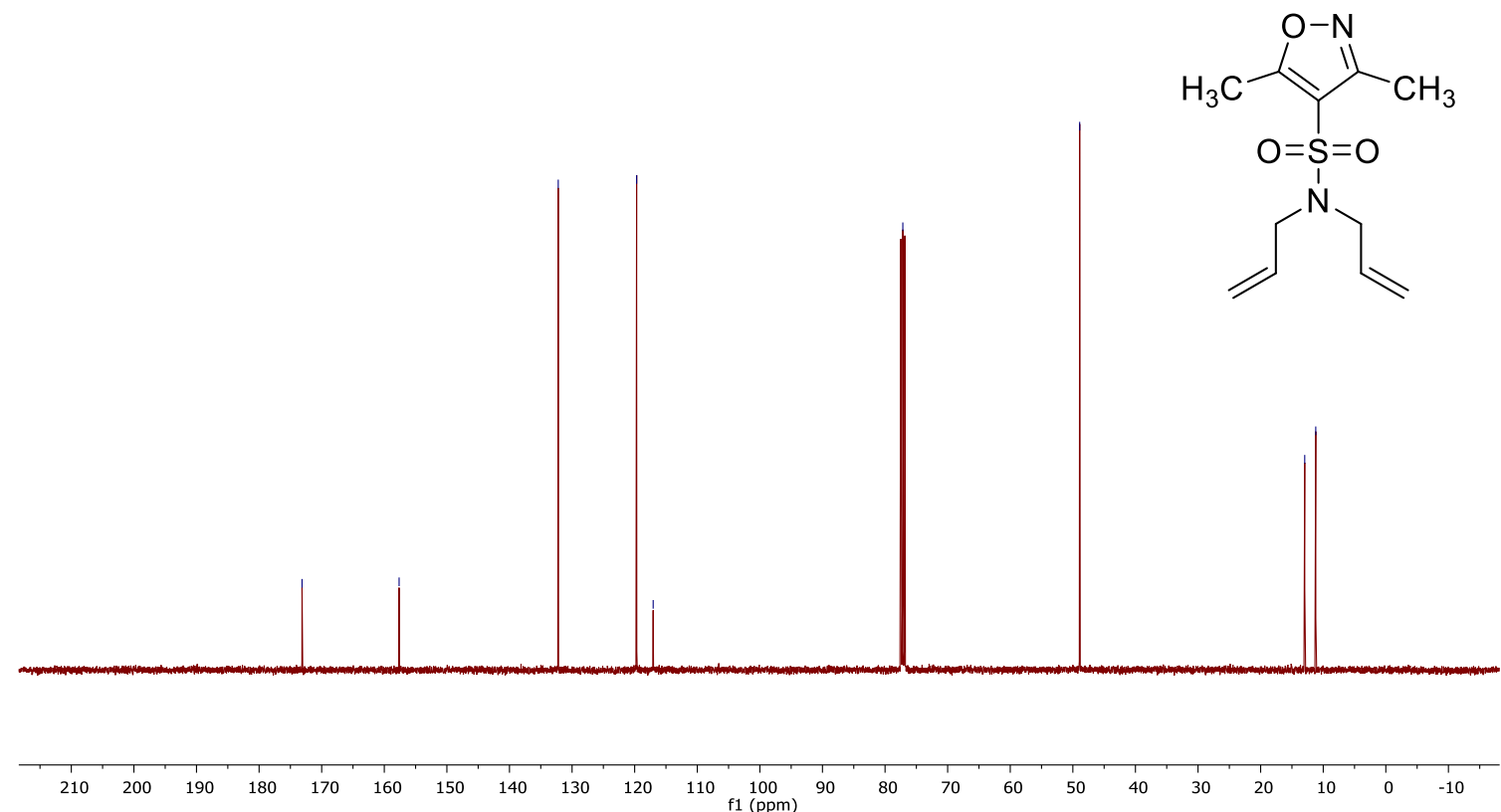

Figure S20. ${ }^{13} \mathrm{C}$ NMR spectrum of $\mathbf{S 1 1}\left(\mathrm{C}_{6} \mathrm{D}_{6}, 101 \mathrm{MHz}, 24^{\circ} \mathrm{C}\right)$. 


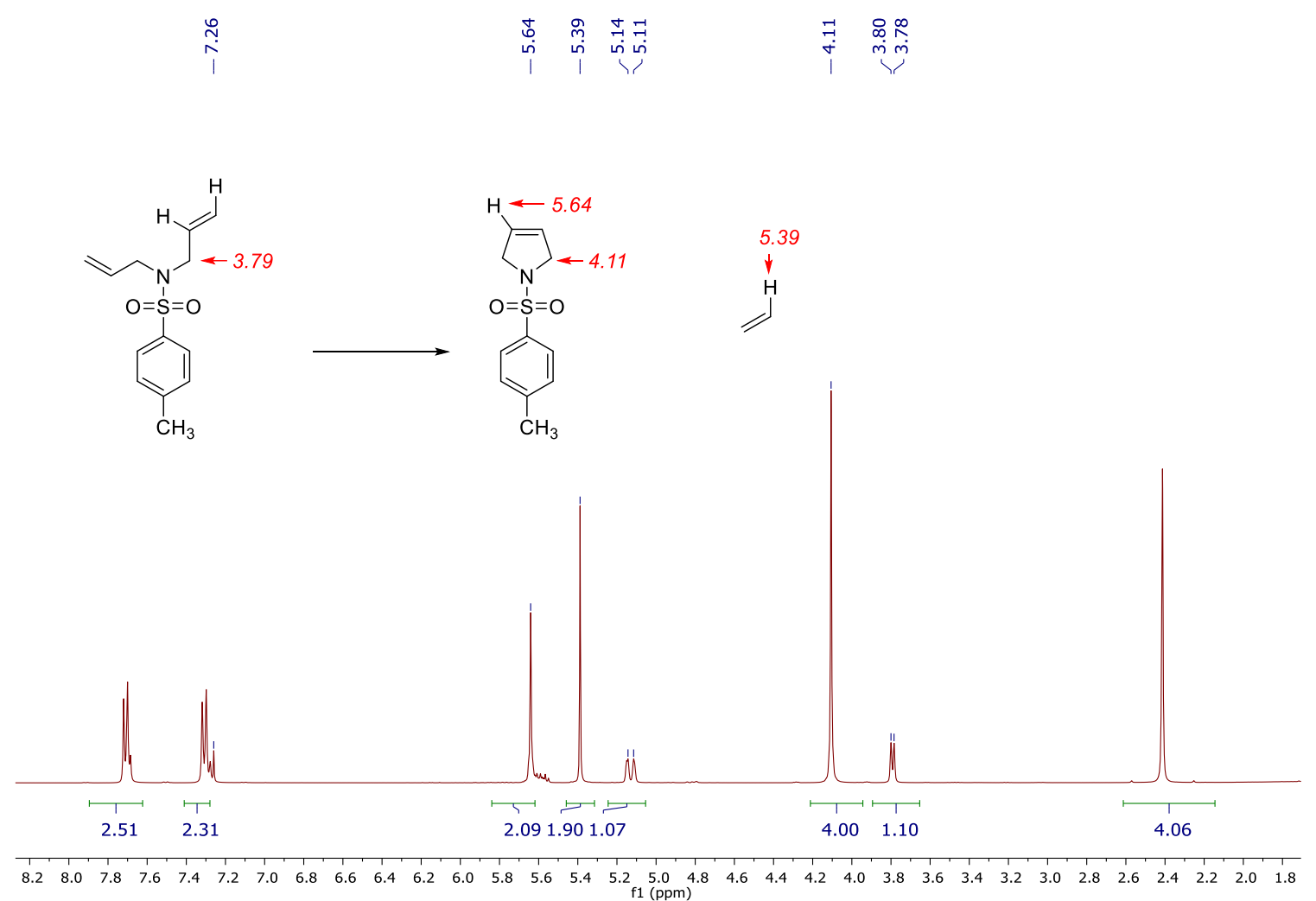

Figure S21. ${ }^{1} \mathrm{H}$ NMR spectra of indicative chemical shifts used for calculation of conversion of compounds 17 to $18\left(\mathrm{CDCl}_{3}, 400 \mathrm{MHz}, 24^{\circ} \mathrm{C}\right)$.

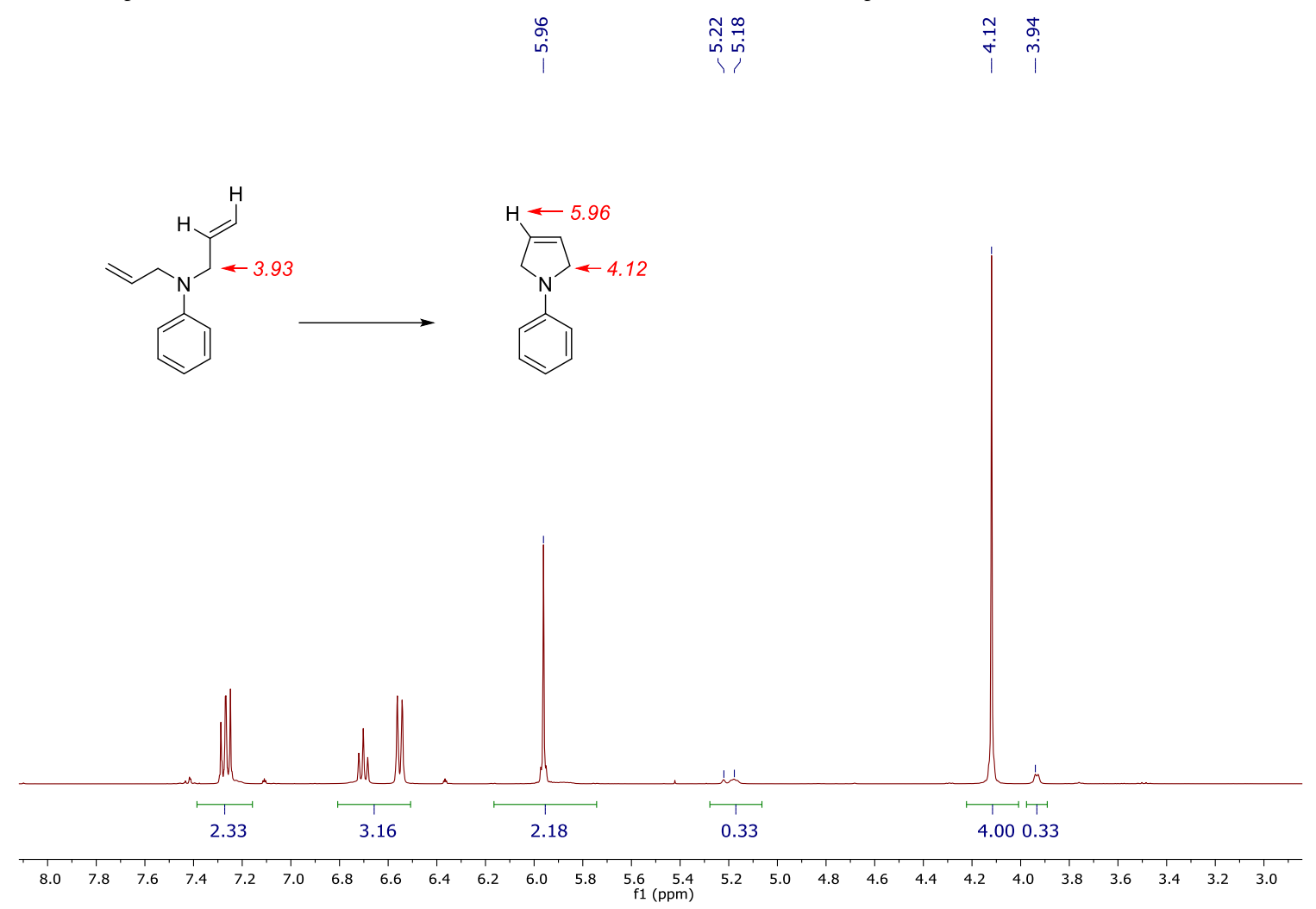

Figure S22. ${ }^{1} \mathrm{H}$ NMR spectra of indicative chemical shifts used for calculation of conversion of compounds $\mathbf{S 6}$ to $19\left(\mathrm{CDCl}_{3}, 400 \mathrm{MHz}, 24^{\circ} \mathrm{C}\right)$. 


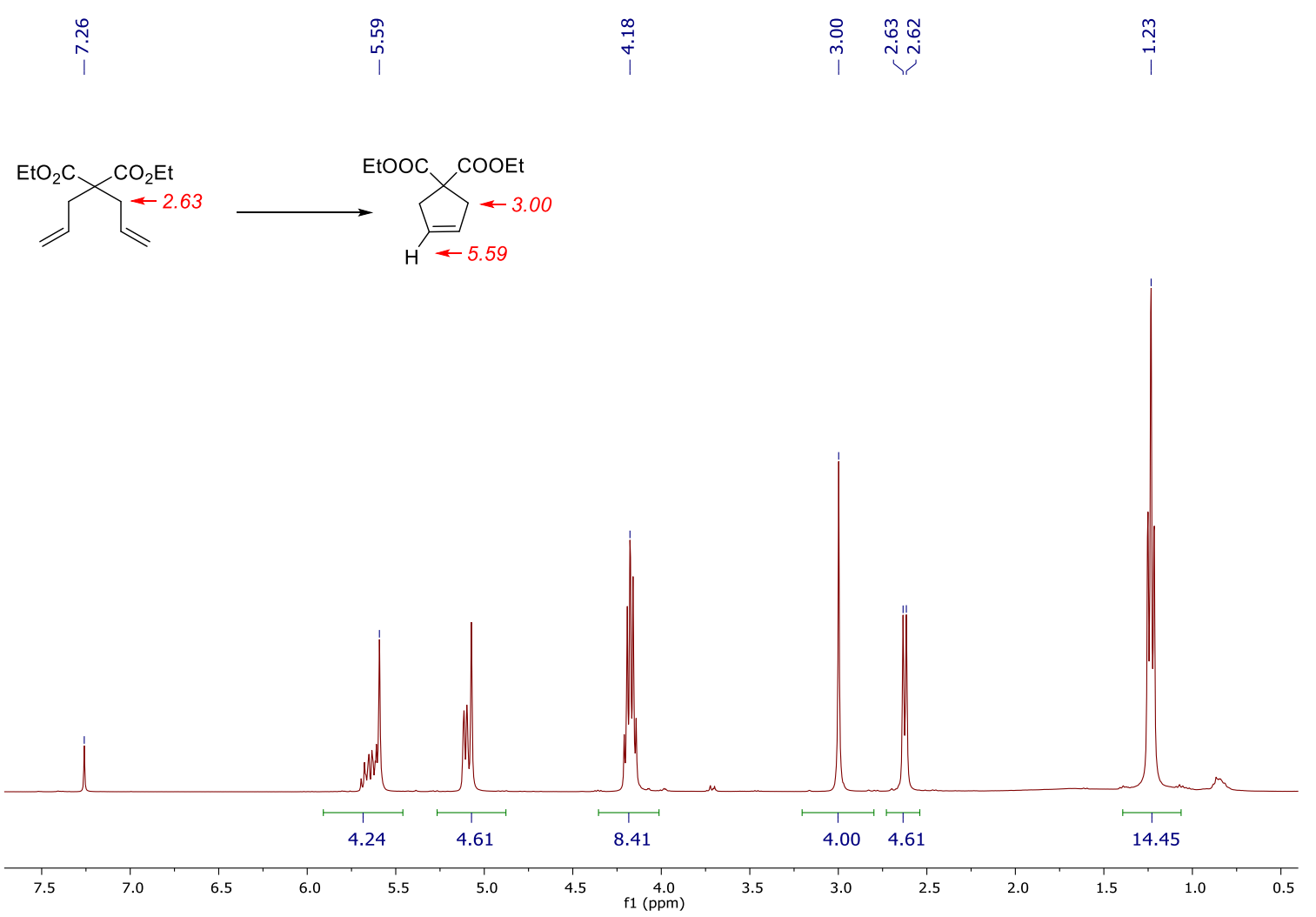

Figure S23. ${ }^{1} \mathrm{H}$ NMR spectra of indicative chemical shifts used for calculation of conversion of compounds $\mathbf{S 8}$ to $20\left(\mathrm{CDCl} 3,400 \mathrm{MHz}, 24^{\circ} \mathrm{C}\right)$.
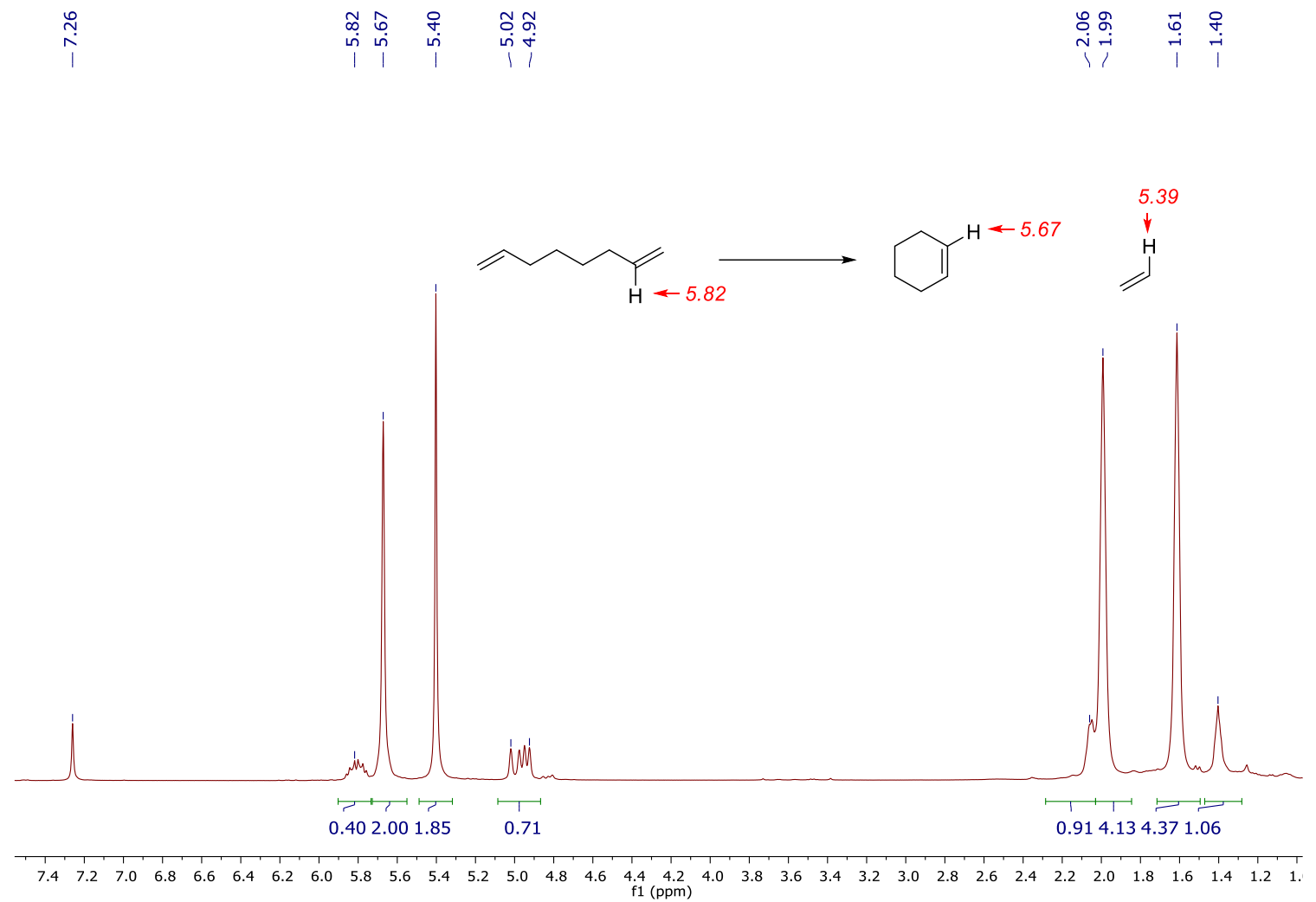

Figure S24. ${ }^{1} \mathrm{H}$ NMR spectra of indicative chemical shifts used for calculation of conversion of compounds $\mathbf{S 1}$ to $21\left(\mathrm{CDCl}_{3}, 400 \mathrm{MHz}, 24^{\circ} \mathrm{C}\right)$. 


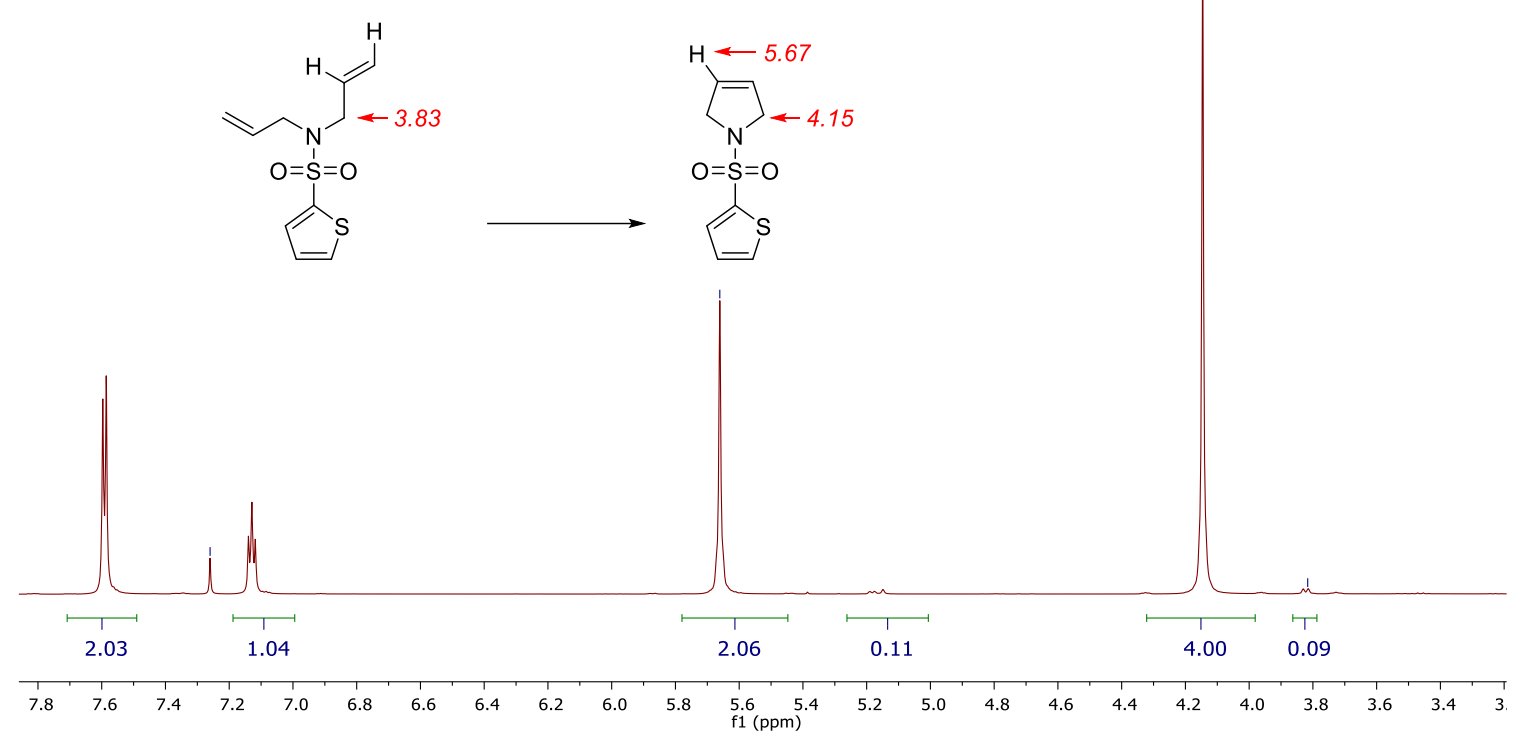

Figure S25. ${ }^{1} \mathrm{H}$ NMR spectra of indicative chemical shifts used for calculation of conversion of compounds $\mathbf{S 5}$ to $22\left(\mathrm{CDCl}_{3}, 400 \mathrm{MHz}, 24^{\circ} \mathrm{C}\right)$.

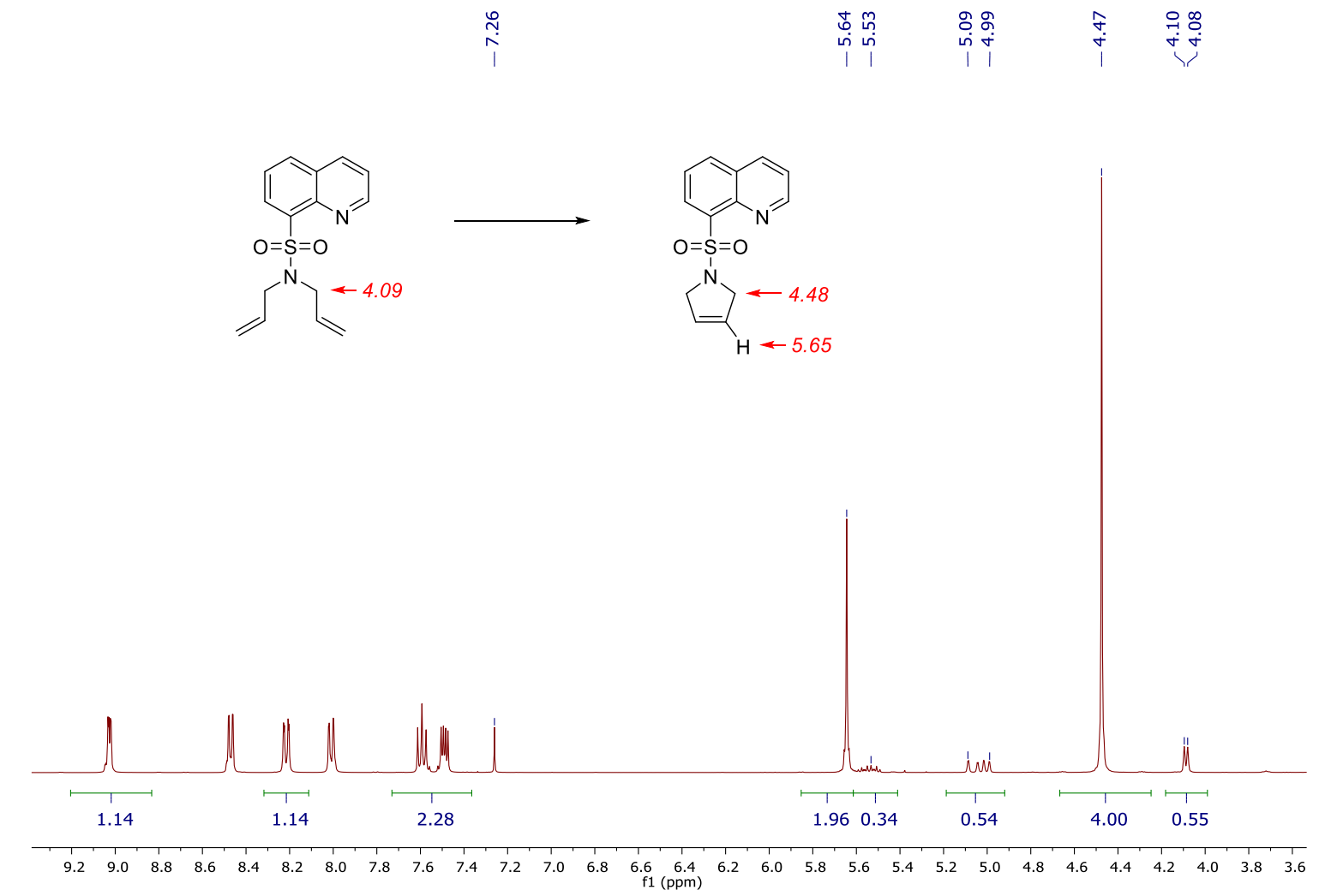

Figure S26. ${ }^{1} \mathrm{H}$ NMR spectra of indicative chemical shifts used for calculation of conversion of compounds $\mathbf{S 9}$ to $23\left(\mathrm{CDCl} 3,400 \mathrm{MHz}, 24^{\circ} \mathrm{C}\right)$. 


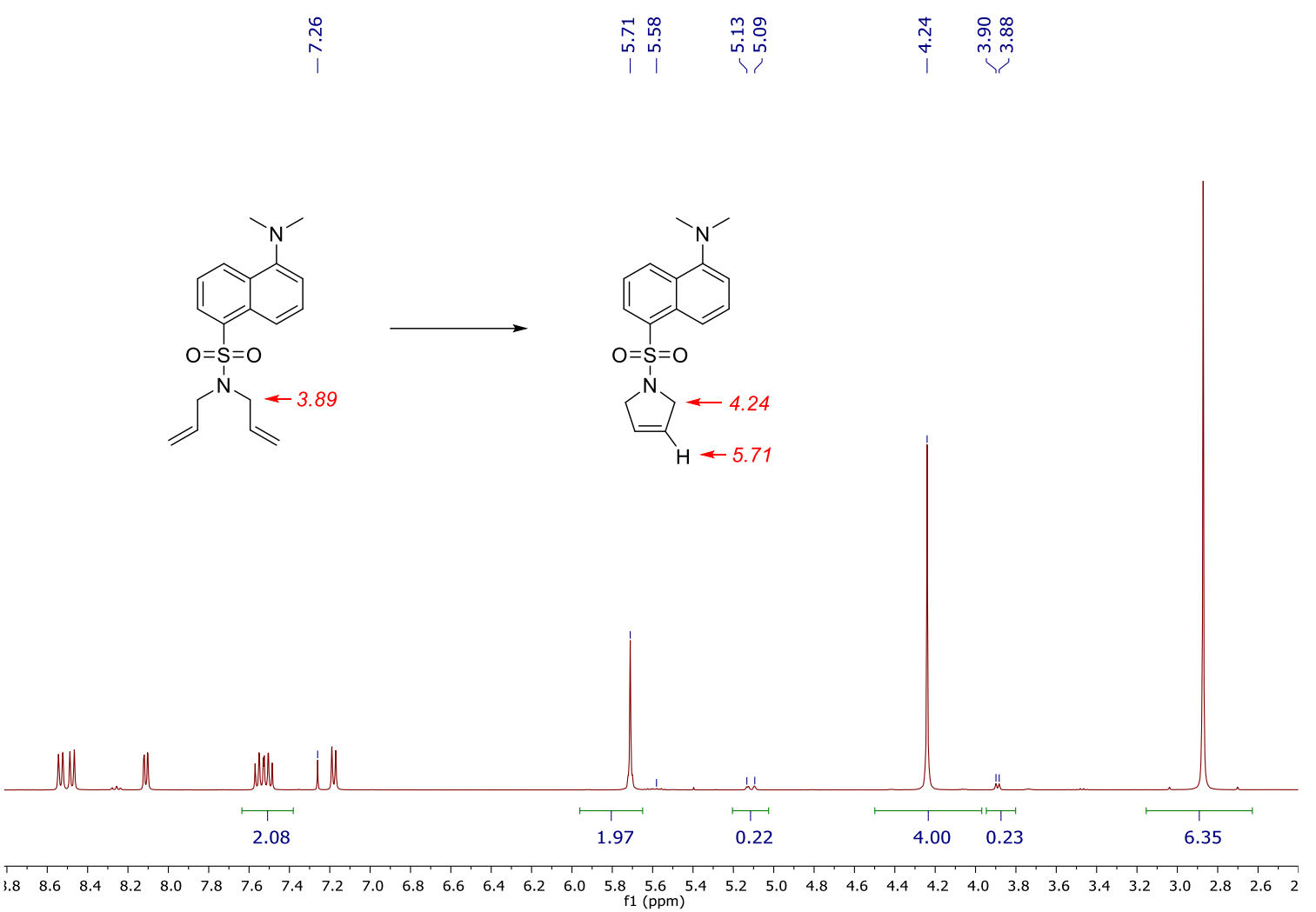

Figure S27. ${ }^{1} \mathrm{H}$ NMR spectra of indicative chemical shifts used for calculation of conversion of compounds $\mathbf{S 1 0}$ to $24\left(\mathrm{CDCl}_{3}, 400 \mathrm{MHz}^{\circ} 24^{\circ} \mathrm{C}\right)$.
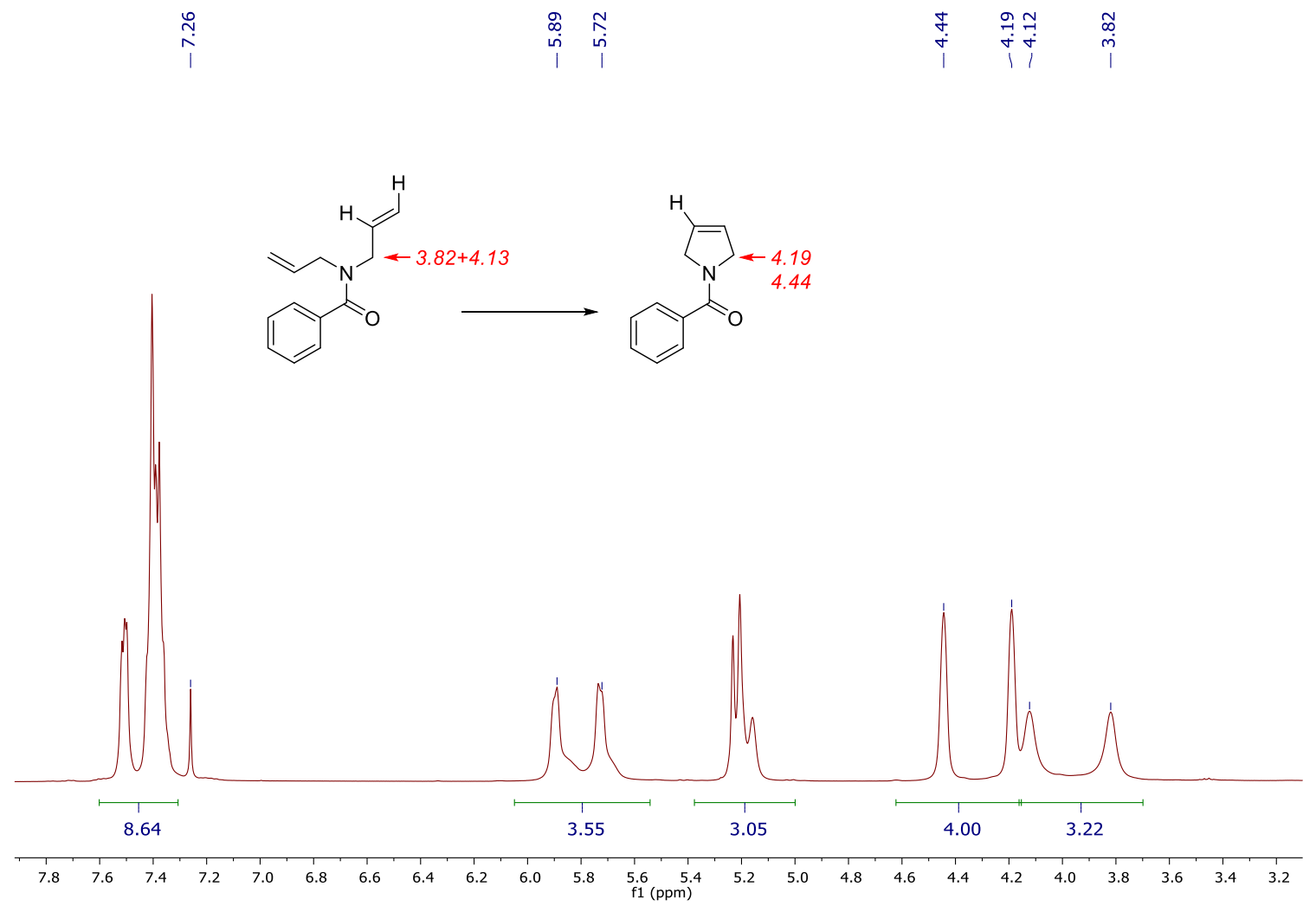

Figure S28. ${ }^{1} \mathrm{H}$ NMR spectra of indicative chemical shifts used for calculation of conversion of compounds $\mathbf{S 7}$ to $25\left(\mathrm{CDCl}_{3}, 400 \mathrm{MHz}, 24^{\circ} \mathrm{C}\right)$. 

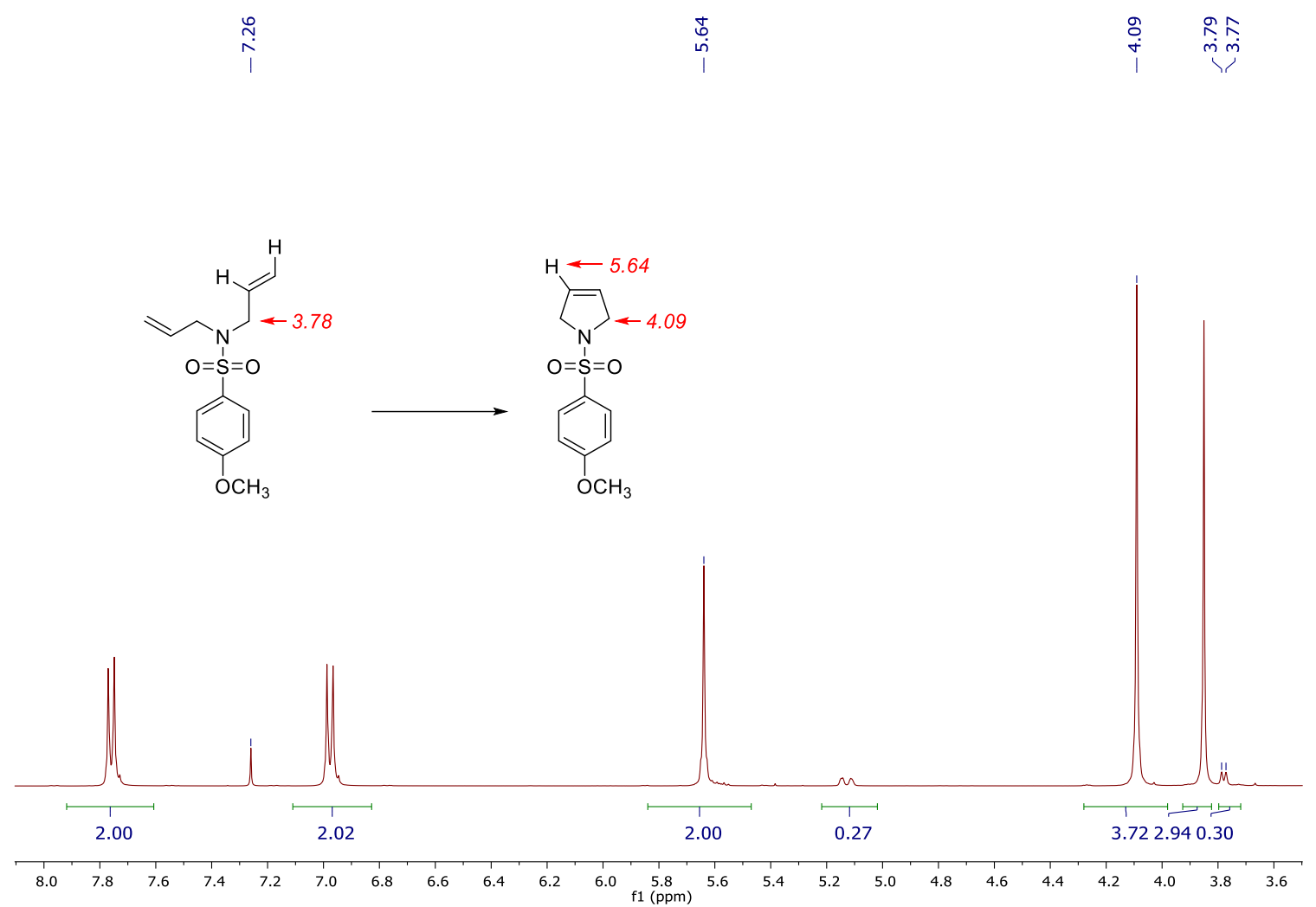

Figure S29. ${ }^{1} \mathrm{H}$ NMR spectra of indicative chemical shifts used for calculation of conversion of compounds $\mathbf{S} 4$ to $26\left(\mathrm{CDCl}_{3}, 400 \mathrm{MHz}, 24^{\circ} \mathrm{C}\right)$.

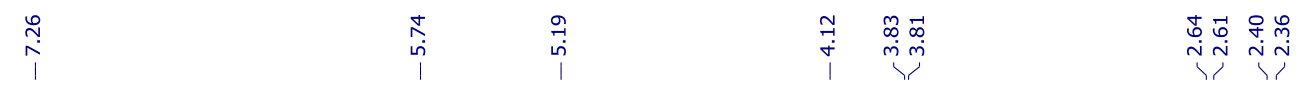
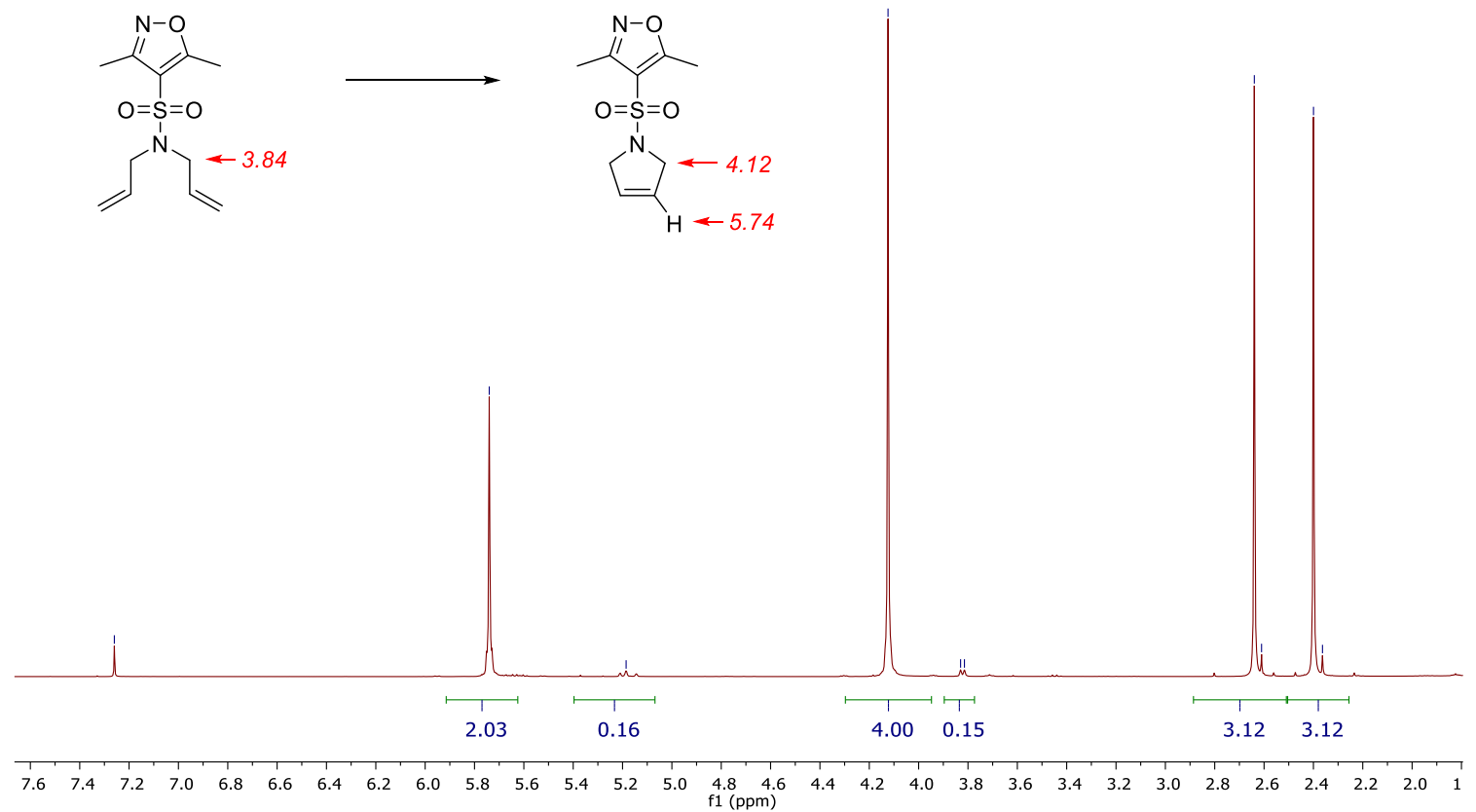

Figure S30. ${ }^{1} \mathrm{H}$ NMR spectra of indicative chemical shifts used for calculation of conversion of compounds $\mathbf{S 1 1}$ to $27\left(\mathrm{CDCl} 3,400 \mathrm{MHz}, 24^{\circ} \mathrm{C}\right)$. 

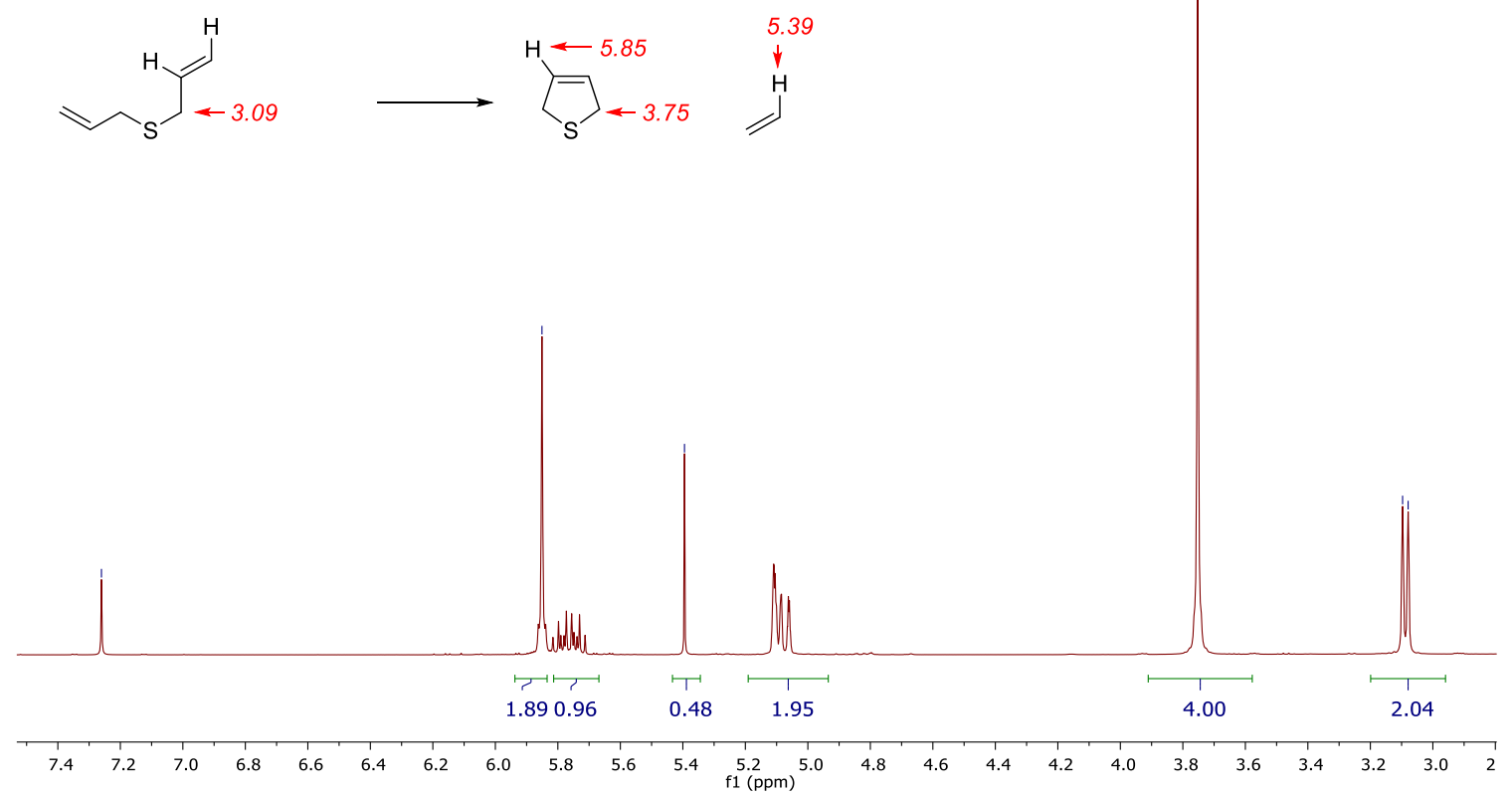

Figure S31. ${ }^{1} \mathrm{H}$ NMR spectra of indicative chemical shifts used for calculation of conversion of compounds $\mathbf{S 2}$ to $28\left(\mathrm{CDCl}_{3}, 400 \mathrm{MHz}, 24^{\circ} \mathrm{C}\right)$. 


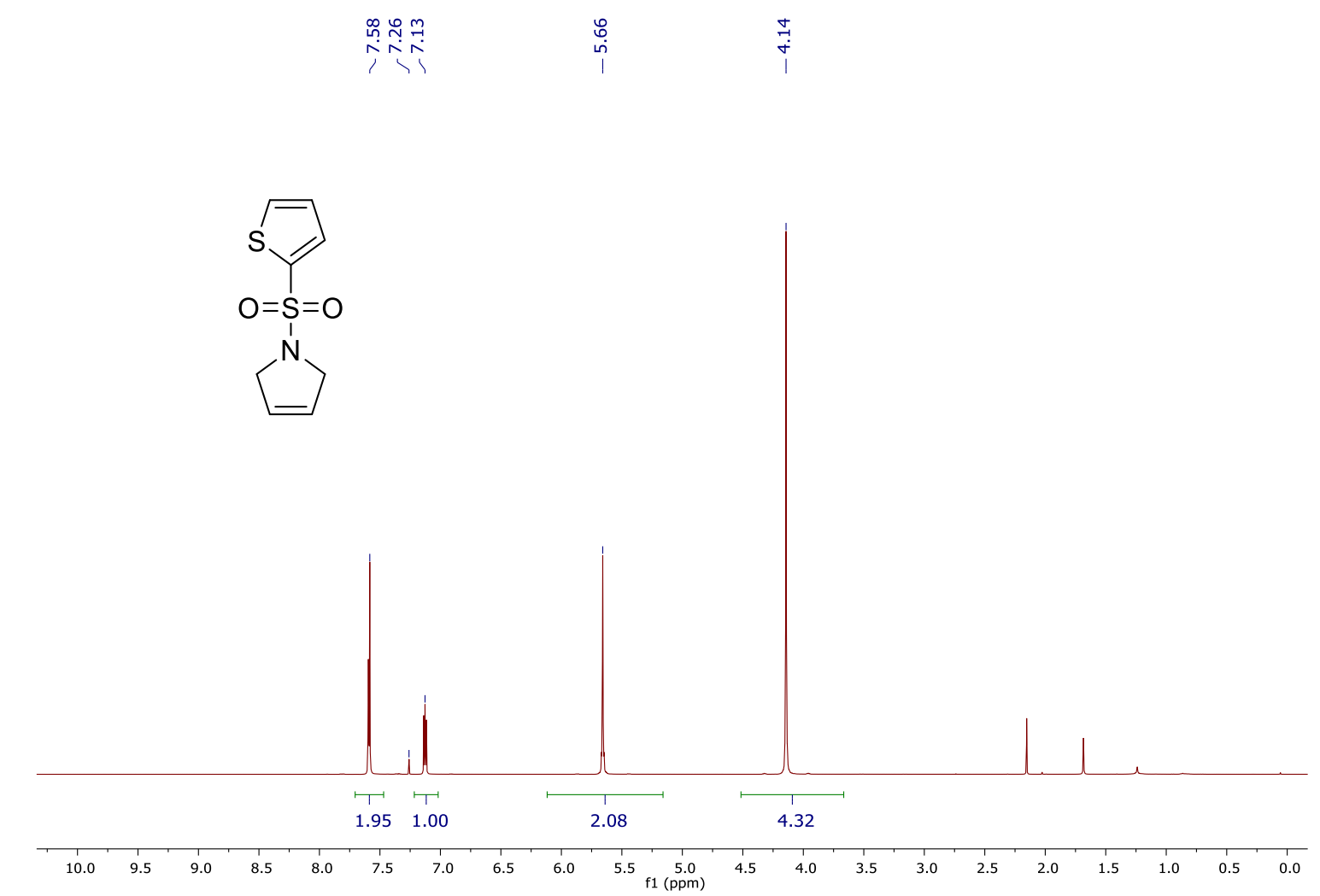

Figure S32. ${ }^{1} \mathrm{H}$ NMR spectrum $22\left(\mathrm{C}_{6} \mathrm{D}_{6}, 400 \mathrm{MHz}, 24^{\circ} \mathrm{C}\right)$.

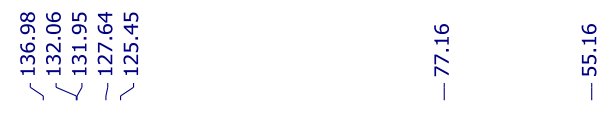
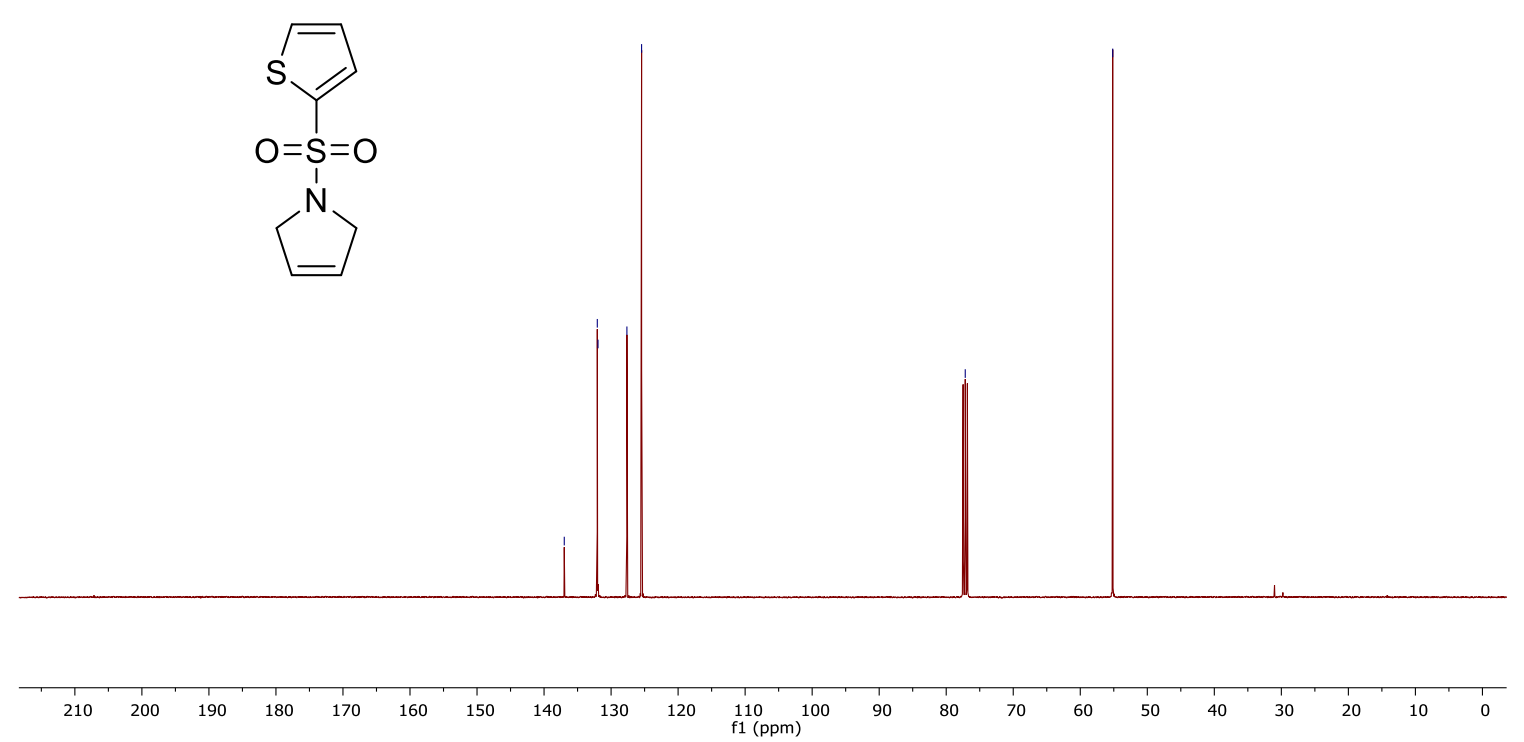

Figure S33. ${ }^{13} \mathrm{C}$ NMR spectrum of $22\left(\mathrm{C}_{6} \mathrm{D}_{6}, 101 \mathrm{MHz}, 24^{\circ} \mathrm{C}\right)$. 


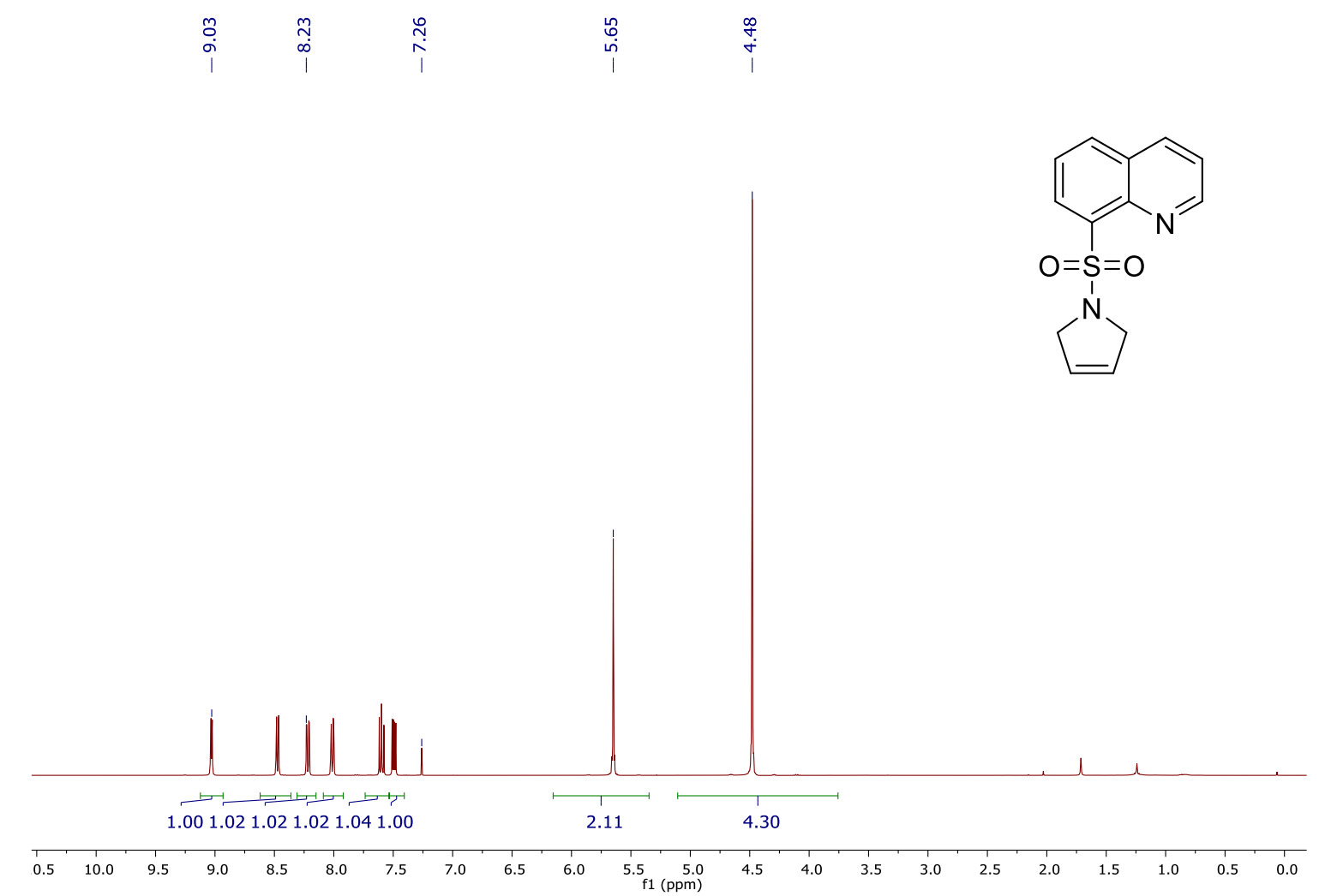

Figure S34. ${ }^{1} \mathrm{H}$ NMR spectrum $23\left(\mathrm{C}_{6} \mathrm{D}_{6}, 400 \mathrm{MHz}, 24^{\circ} \mathrm{C}\right)$.

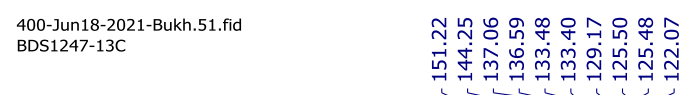

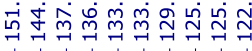

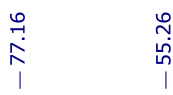

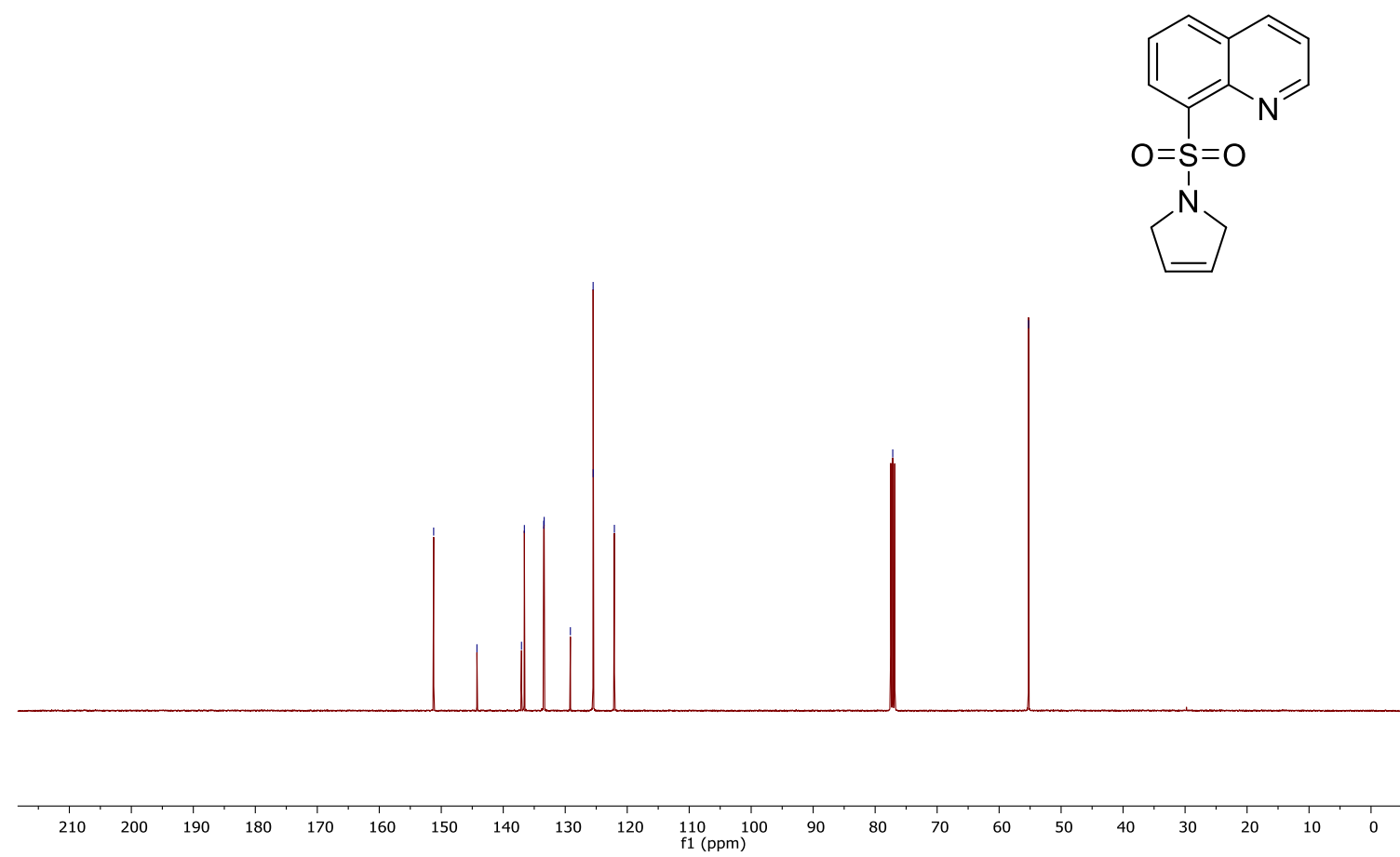

Figure S35. ${ }^{13} \mathrm{C}$ NMR spectrum of $23\left(\mathrm{C}_{6} \mathrm{D}_{6}, 101 \mathrm{MHz}, 24^{\circ} \mathrm{C}\right)$. 


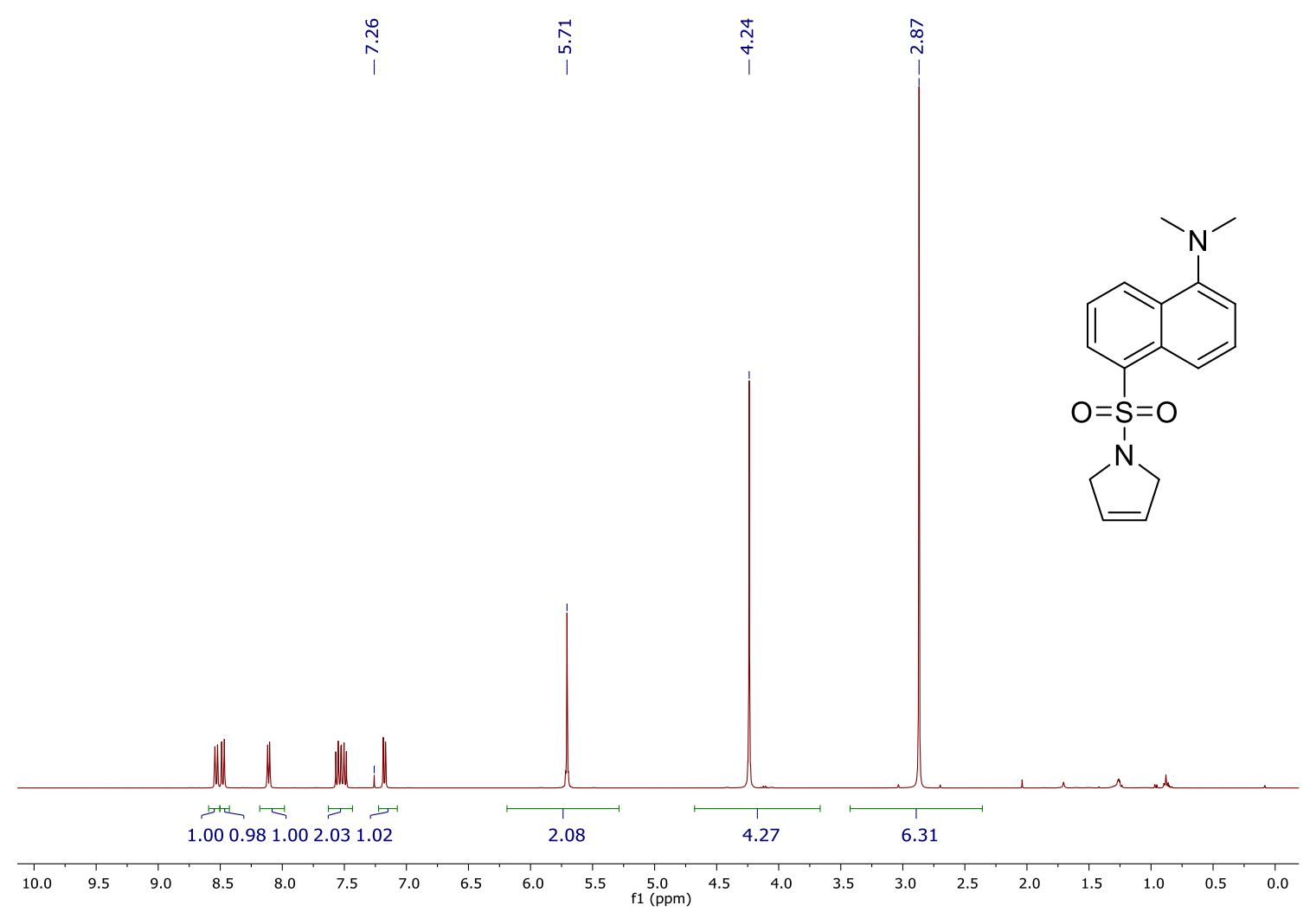

Figure S36. ${ }^{1} \mathrm{H}$ NMR spectrum $24\left(\mathrm{C}_{6} \mathrm{D}_{6}, 400 \mathrm{MHz}, 24^{\circ} \mathrm{C}\right)$.
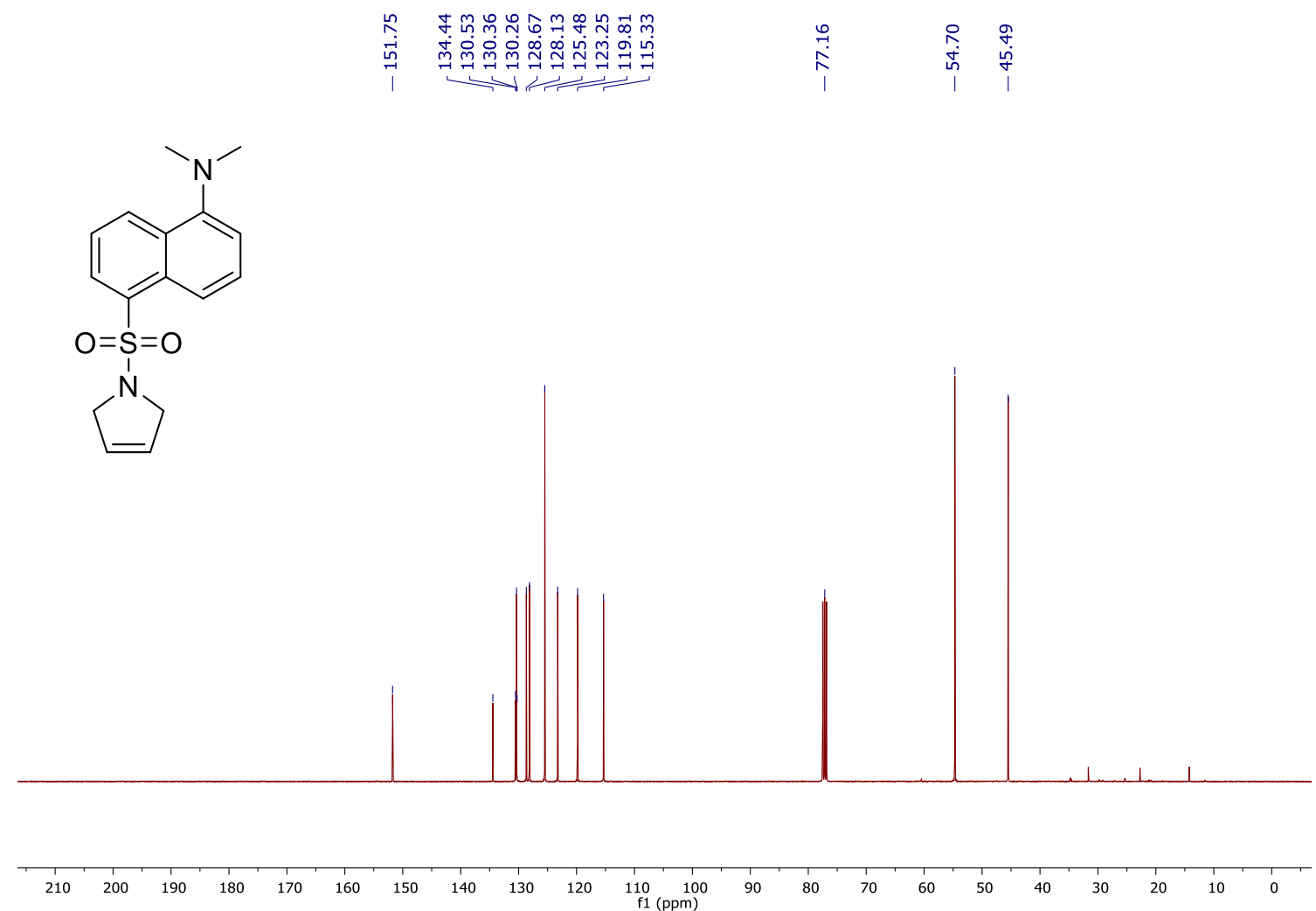

Figure S37. ${ }^{13} \mathrm{C}$ NMR spectrum of $24\left(\mathrm{C}_{6} \mathrm{D}_{6}, 101 \mathrm{MHz}, 24^{\circ} \mathrm{C}\right)$. 


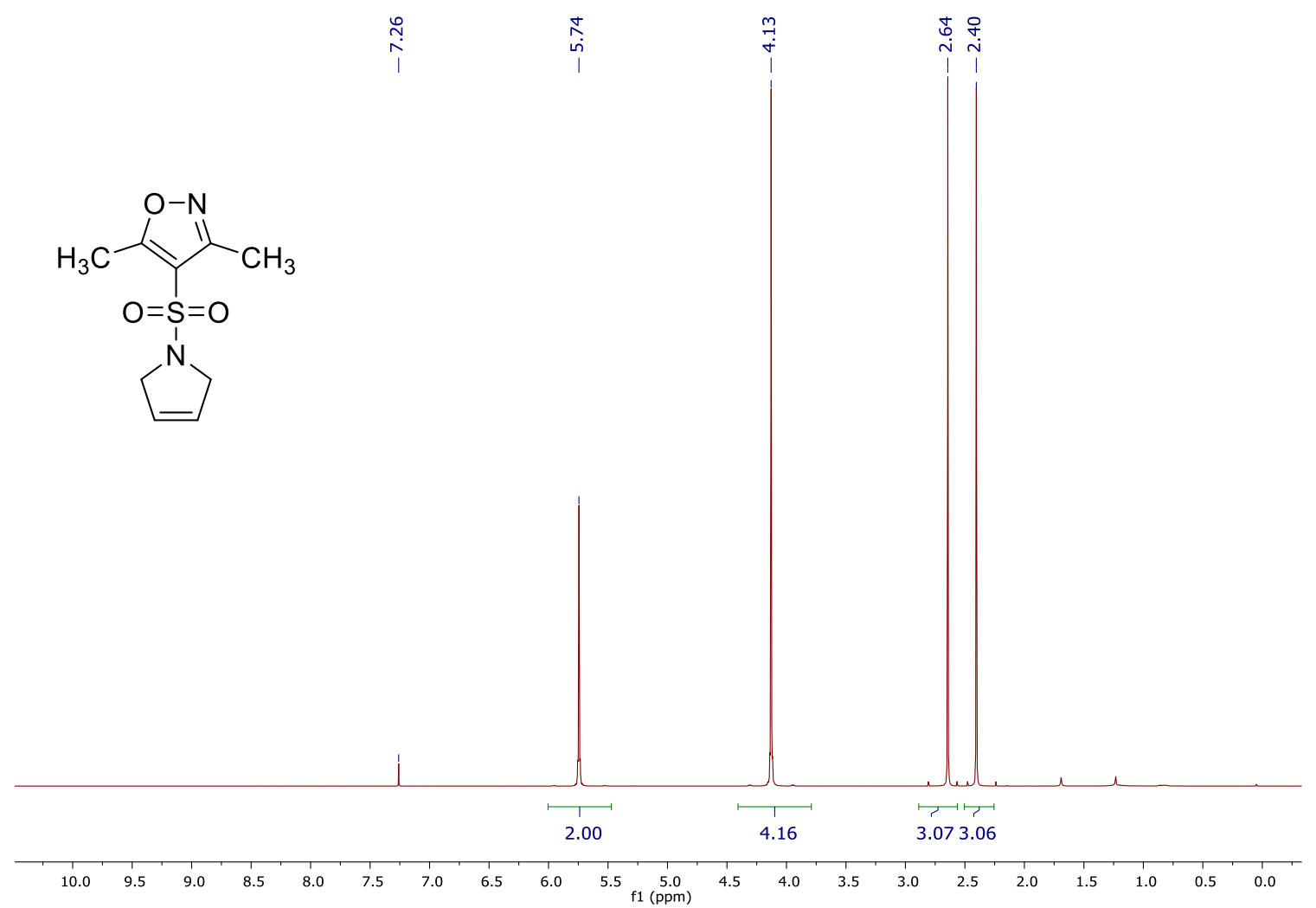

Figure S38. ${ }^{1} \mathrm{H}$ NMR spectrum $27\left(\mathrm{C}_{6} \mathrm{D}_{6}, 400 \mathrm{MHz}, 24^{\circ} \mathrm{C}\right)$.

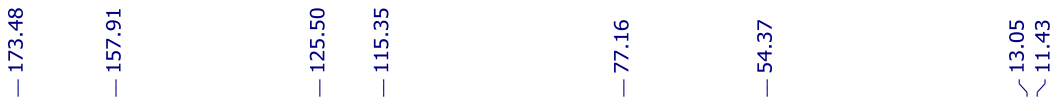
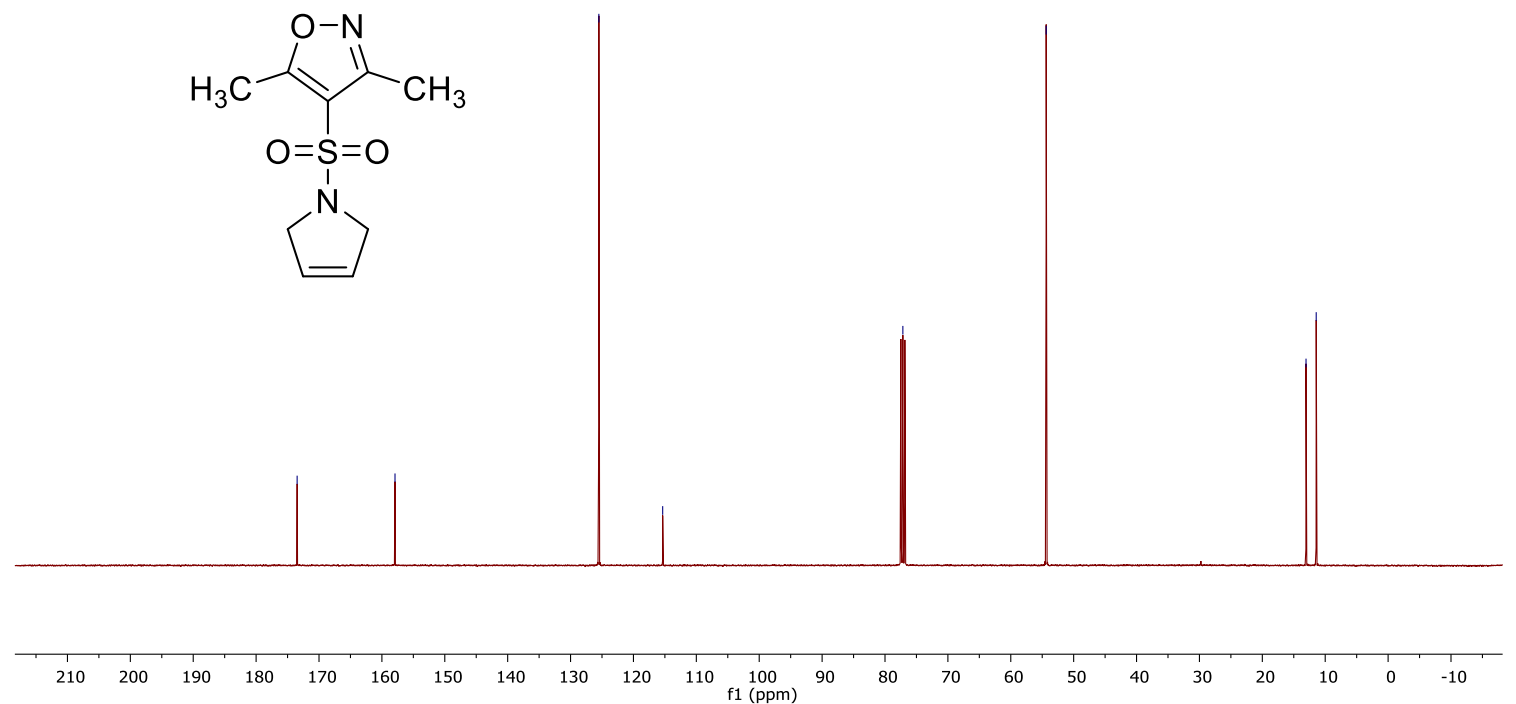

Figure S39. ${ }^{13} \mathrm{C}$ NMR spectrum of $27\left(\mathrm{C}_{6} \mathrm{D}_{6}, 101 \mathrm{MHz}, 24^{\circ} \mathrm{C}\right)$. 


\section{References:}

1. Razuvaev, G. A.; Latyaeva, V. N.; Vyshinskaya, L. I.; Drobotenko, V. V., Synthesis and properties of covalent tri- and tetravalent vanadium. J. Organomet. Chem. 1981, 208 (2), 169-182. 2. Manzer, L. E.; Mintz, E. A.; Marks, T. J., Tetrahydrofuran Complexes of Selected Early Transition Metals. Inorg. Synth. 1982, 21, 135-140.

3. So, C. M.; Kume, S.; Hayashi, T., Rhodium-Catalyzed Asymmetric Hydroarylation of 3Pyrrolines Giving 3-Arylpyrrolidines: Protonation as a Key Step. J. Am. Chem. Soc. 2013, 135 (30), 10990-10993.

4. Chen, W.; Zhang, Y.-L.; Li, H.-J.; Nan, X.; Liu, Y.; Wu, Y.-C., Synthesis of N-Sulfonyland N-Acylpyrroles via a Ring-Closing Metathesis/Dehydrogenation Tandem Reaction. Synthesis 2019, 51 (19), 3651-3666.

5. Schmidt, B.; Krehl, S.; Jablowski, E., Assisted tandem catalytic RCM-aromatization in the synthesis of pyrroles and furans. Org. Biomol. Chem. 2012, 10 (26), 5119-5130.

6. Kobayashi, Y.; Inukai, S.; Kondo, N.; Watanabe, T.; Sugiyama, Y.; Hamamoto, H.; Shioiri, T.; Matsugi, M., A medium fluorous Grubbs-Hoveyda 2nd generation catalyst for phase transfer catalysis of ring closing metathesis reactions. Tetrahedron Lett. 2015, 56 (11), 1363-1366.

7. Kamimura, A.; Kawakami, Y., A radical cascade reaction triggered by thiyl radical; an approach toward synthesis of tricyclic structure of platensimycin. Phosphorus, Sulfur, and Silicon and the Related Elements 2016, 191 (2), 259-262.

8. Scalacci, N.; Black, G. W.; Mattedi, G.; Brown, N. L.; Turner, N. J.; Castagnolo, D., Unveiling the Biocatalytic Aromatizing Activity of Monoamine Oxidases MAO-N and 6-HDNO: Development of Chemoenzymatic Cascades for the Synthesis of Pyrroles. ACS Catalysis 2017, 7 (2), 1295-1300.

9. Yao, Q.; Zhang, Y., Poly(fluoroalkyl acrylate)-Bound Ruthenium Carbene Complex: A Fluorous and Recyclable Catalyst for Ring-Closing Olefin Metathesis. J. Am. Chem. Soc. 2004, $126(1), 74-75$.

10. Edwards, G. A.; Culp, P. A.; Chalker, J. M., Allyl sulphides in olefin metathesis: catalyst considerations and traceless promotion of ring-closing metathesis. Chem. Commun. 2015, 51 (3), 515-518.

11. Becke, A. D., Density-functional thermochemistry. III. The role of exact exchange. The Journal of Chemical Physics 1993, 98 (7), 5648-5652.

12. Lee, C.; Yang, W.; Parr, R. G., Development of the Colle-Salvetti correlation-energy formula into a functional of the electron density. Phys Rev B Condens Matter 1988, 37 (2), 785789.

13. Frisch, M. J.; Trucks, G. W.; Schlegel, H. B.; Scuseria, G. E.; Robb, M. A.; Cheeseman, J. R.; Scalmani, G.; Barone, V.; Petersson, G. A.; Nakatsuji, H.; Li, X.; Caricato, M.; Marenich, A. V.; Bloino, J.; Janesko, B. G.; Gomperts, R.; Mennucci, B.; Hratchian, H. P.; Ortiz, J. V.; Izmaylov, A. F.; Sonnenberg, J. L.; Williams; Ding, F.; Lipparini, F.; Egidi, F.; Goings, J.; Peng, B.; Petrone, A.; Henderson, T.; Ranasinghe, D.; Zakrzewski, V. G.; Gao, J.; Rega, N.; Zheng, G.; Liang, W.; Hada, M.; Ehara, M.; Toyota, K.; Fukuda, R.; Hasegawa, J.; Ishida, M.; Nakajima, T.; Honda, Y.; Kitao, O.; Nakai, H.; Vreven, T.; Throssell, K.; Montgomery Jr., J. A.; Peralta, J. E.; Ogliaro, F.; Bearpark, M. J.; Heyd, J. J.; Brothers, E. N.; Kudin, K. N.; Staroverov, V. N.; Keith, T. A.; Kobayashi, R.; Normand, J.; Raghavachari, K.; Rendell, A. P.; Burant, J. C.; Iyengar, S. S.; Tomasi, J.; Cossi, M.; Millam, J. M.; Klene, M.; Adamo, C.; Cammi, R.; Ochterski, J. W.; Martin, R. L.; Morokuma, K.; Farkas, O.; Foresman, J. B.; Fox, D. J. Gaussian 16 Rev. A.03, Wallingford, CT, 2016. 
14. Grimme, S.; Antony, J.; Ehrlich, S.; Krieg, H., A consistent and accurate ab initio parametrization of density functional dispersion correction (DFT-D) for the 94 elements H-Pu. $J$. Chem. Phys. 2010, 132 (15), 154104.

15. Zhao, Y.; Truhlar, D. G., The M06 suite of density functionals for main group thermochemistry, thermochemical kinetics, noncovalent interactions, excited states, and transition elements: two new functionals and systematic testing of four M06-class functionals and 12 other functionals. Theor. Chem. Acc. 2007, 120 (1-3), 215-241.

16. Zhao, Y.; Truhlar, D. G., Density functionals with broad applicability in chemistry. Acc. Chem. Res. 2008, 41 (2), 157-167.

17. Hehre, W. J.; Ditchfield, R.; Pople, J. A., Self-Consistent Molecular Orbital Methods. XII. Further Extensions of Gaussian-Type Basis Sets for Use in Molecular Orbital Studies of Organic Molecules. The Journal of Chemical Physics 1972, 56 (5), 2257-2261.

18. Francl, M. M.; Pietro, W. J.; Hehre, W. J.; Binkley, J. S.; Gordon, M. S.; DeFrees, D. J.; Pople, J. A., Self-consistent molecular orbital methods. XXIII. A polarization-type basis set for second-row elements. The Journal of Chemical Physics 1982, 77 (7), 3654-3665.

19. Wachters, A. J. H., Gaussian Basis Set for Molecular Wavefunctions Containing ThirdRow Atoms. The Journal of Chemical Physics 1970, 52 (3), 1033-1036.

20. Bauschlicher, C. W.; Langhoff, S. R.; Partridge, H.; Barnes, L. A., Theoretical studies of the first- and second-row transition-metal methyls and their positive ions. The Journal of Chemical Physics 1989, 91 (4), 2399-2411.

21. Marenich, A. V.; Cramer, C. J.; Truhlar, D. G., Universal solvation model based on solute electron density and on a continuum model of the solvent defined by the bulk dielectric constant and atomic surface tensions. J. Phys. Chem. B 2009, 113 (18), 6378-96.

22. Rush, L. E.; Pringle, P. G.; Harvey, J. N., Computational kinetics of cobalt-catalyzed alkene hydroformylation. Angew. Chem. Int. Ed. 2014, 53 (33), 8672-8676.

23. Besora, M.; Maseras, F., Microkinetic modeling in homogeneous catalysis. WIREs Computational Molecular Science 2018, 8 (6).

24. Lee, A. M.; Handy, N. C.; Colwell, S. M., The density functional calculation of nuclear shielding constants using London atomic orbitals. The Journal of Chemical Physics 1995, 103 (23), 10095-10109. 